NBER WORKING PAPER SERIES

\title{
PEOPLE'S OPIUM? RELIGION AND ECONOMIC ATTITUDES
}

\author{
Luigi Guiso \\ Paola Sapienza \\ Luigi Zingales \\ Working Paper 9237 \\ http://www.nber.org/papers/w9237 \\ NATIONAL BUREAU OF ECONOMIC RESEARCH \\ 1050 Massachusetts Avenue \\ Cambridge, MA 02138 \\ October 2002
}

We thank Roc Armenter for excellent research assistantship, Chiara Corti and Adam Cartabiano for their help in inputting the tables, Jason Hwang for his great help with the WVS coding, and Louise Kelley and participants to the 2002 Carnegie Rochester series for comments. Luigi Guiso also thanks MURST and the EEC and Luigi Zingales the Stigler Center at the University of Chicago for financial support. The views expressed herein are those of the authors and not necessarily those of the National Bureau of Economic Research.

(C) 2002 by Luigi Guiso, Paola Sapienza, and Luigi Zingales. All rights reserved. Short sections of text, not to exceed two paragraphs, may be quoted without explicit permission provided that full credit, including (C) notice, is given to the source. 
People's Opium? Religion and Economic Attitudes

Luigi Guiso, Paola Sapienza, and Luigi Zingales

NBER Working Paper No. 9237

October 2002

JEL No. O57, O40, P51

\begin{abstract}
$\underline{\text { ABSTRACT }}$
Since Max Weber, there has been an active debate on the impact of religion on people's economic attitudes. Much of the existing evidence, however, is based on cross-country studies in which this impact is confounded by differences in other institutional factors. We use the World Values Surveys to identify the relationship between intensity of religious beliefs and economic attitudes, controlling for country fixed effects. We study several economic attitudes toward cooperation, the government, working women, legal rules, thriftiness, and the market economy. We also distinguish across religious denominations, differentiating on whether a religion is dominant in a country. We find that on average, religious beliefs are associated with "good" economic attitudes, where "good" is defined as conducive to higher per capita income and growth. Yet religious people tend to be more racist and less favorable with respect to working women. These effects differ across religious denominations. Overall, we find that Christian religions are more positively associated with attitudes conducive to economic growth.
\end{abstract}

Luigi Guiso

Ente Per Gli Studi Bancari

Luigi Einaudi

Via Due Macelli 73

00187 Rome

ITALY

guiso@tin.it

Luigi Zingales

University of Chicago

1101 East $58^{\text {th }}$ Street

Chicago, Illinois 60637

and NBER, CEPR

luigi.zinagles@gsb.uchicago.edu
Paola Sapienza

Kellogg Graduate School of Management

Finance Department

Northwestern University

2001 Sheridan Road

Evanston, Illinois 60208-2001

paola-sapienza@kellogg.nwu.edu 
Economists, sociologists, and political scientists have long been interested in explaining the economic success of certain countries and the persistent poverty of others. In search of the ultimate cause, an obvious role has been suggested for religion. There is hardly an aspect of a society's life that is not affected by religion. Why shouldn't it affect a country's ability to produce efficiently and grow?

Max Weber (1905) was the first to identify the significant role that religion plays in social change. He went as far as to state that the Protestant Reformation triggered a mental revolution that made possible the advent of modern capitalism.

Almost a century after Weber's seminal work, the importance of religion in explaining the prosperity of nations seems to be experiencing a rebirth. While scholars prefer to avoid correlating religion directly with economic prosperity, they try to relate it to fundamental institutions that have been shown to be conducive to growth. In his study of development across Italy, for instance, Putnam (1993) attributes the prevailing lack of trust toward others in the South to the strong Catholic tradition, which emphasizes the vertical bond with the Church and tends to undermine the horizontal bond with fellow citizens. In a cross-country study, both La Porta et al. (1997) and Inglehart (1999) find some evidence for this theory. On a similar note, Landes (1998) attributes the failure of Spain to develop in the 16th and 17th century to the culture of intolerance diffused by the Catholic Church, which forced some of the most skillful people out of the country. Finally, Stulz and Williamson (2001) attribute the low level of creditors' protection present in Catholic countries to the anti-usury culture pervasive in the Catholic tradition.

Unlike Weber, most of these authors provide compelling evidence in favor of their claim, showing a robust correlation between a country's main religion and these 
institutions. Such evidence, however, can be interpreted in two ways. One possible interpretation is that there is something intrinsic to certain religions, such as Catholicism, that makes them inimical to the development of talents and institutions that foster economic growth. An alternative interpretation, which is equally consistent with the results, is that there was something in the past (correlated with religion, but not necessarily religion) that trapped a country in a bad equilibrium. According to this interpretation, there is nothing fundamental, but it is hysteresis that keeps a country trapped in this equilibrium. A possible variation of this hypothesis, which is observationally equivalent to the previous one, is that there were some aspects of a religion, in this case Catholicism, that were inimical to the development of certain institutions, for example trust, but that these aspects disappeared over time, possibly because of a reform.

While the difference between the two hypotheses seems rather uninteresting from a historical point of view, from a policy perspective it is very important. If the first alternative is true, then short of changing a country's religion (a task beyond the power even of the World Bank), there is very little hope for bringing prosperity to many poor countries. By contrast, the second alternative provides some hope. It is sufficient to find a coordinating device to escape the bad equilibrium trap without trying to change people's religious beliefs.

Unfortunately, the existing cross-country analysis cannot distinguish between these two hypotheses. To identify the effect of religion separately from the effect of other historical accidents, we have to resort to a within country analysis. Such an analysis cannot be conducted in one country alone, because the role of a religion might depend 
highly upon the social and historical context in which it developed. To address this issue in this study, we use a dataset containing data on individuals for a large set of countries. The World Values Survey is actually a collection of surveys administered to a representative sample of people in 66 countries from 1981 to 1997. These questionnaires contain information not only about religious affiliation, but also about the intensity of beliefs (frequency of attending religious services) and how the interviewee was raised (religiously or not). Thus, we are able to study the relation between the degree of religiosity and the type of religion on a series of fundamental societal attitudes that have been shown to be conducive to higher productivity and growth.

We analyze the relation between religion and six groups of variables: people's attitudes toward cooperation, women, government, legal rules, the market economy and its fairness, and thriftiness. As measures of attitudes toward cooperation, we use individual responses to questions regarding how much one trusts other people in general and how tolerant individuals are toward neighbors of different races and/or countries. As measures of attitude toward women, we use responses to a variety of questions ranging from who should get a job first, a man or a woman, when jobs are scarce; whether men should have priority in obtaining university education; and whether both men and women should contribute to household income. As measure of attitudes toward the government, we use individual responses on how much people trust the government and other government institutions. As measures of attitude toward legal norms, we use individual responses regarding trust of the legal system and willingness to break the law, including cheating on taxes, avoiding a fare on public transportation, or paying bribes. The World Values Survey asks people to state their position along the efficiency versus equity trade 
off. The interviewer shows a card to the respondent in which there are two opposite statements at the extremes of a 1 to 10 interval. The respondent chooses the number that best describes his or her relative position. Questions range from whether people think pay inequality is necessary to provide better incentives to whether competition brings out the worst in people or stimulates hard work and new ideas. Finally, to measure people's attitudes toward thriftiness, we use responses to a question concerning whether it is especially important to instill the "virtue" of thriftiness in children.

To isolate the effect of religion from other confounding effects, we control for country fixed effects and several individual characteristics: health status, age, sex, education, income, and perceived social status.

We find that on average religion is associated positively with attitudes that are conducive to free markets and better institutions. Religious people trust others more, trust the government and the legal system more, are less willing to break the law, and are more likely to believe that markets' outcomes are fair. The relation between religiosity and market mechanisms (incentives, competition, and private property) is more mixed. On the negative side, religious people are more intolerant and less sympathetic to women's rights.

The aspect of religion that is associated with economic attitudes is different across the intensity of religious beliefs. Trust toward others is associated mostly with religious participation, not religious upbringing. By contrast, intolerance is mostly an outcome of being raised religiously. Active churchgoers are not more intolerant toward immigrants than the rest of the population (but not less either) and they are less 
sympathetic to women's rights. Finally, both a religious upbringing and active religious participation increase trust toward government institutions.

We find that different religions have different effects on people's attitudes. Participation to religious services increases trust only among Christians. The effect is zero or even negative for other denominations. Within the Christian family, the effect is stronger for Protestant than for Catholics, as suggested by Putnam (1993).

The relation between religion and intolerance is present in all religious denominations. The only exception is Buddhists who are more tolerant than non-religious people. Hindus and Muslim are the less tolerant towards immigrants and other races, followed by Jews, Catholics and Protestants. The point estimates for Protestants and Catholics are very similar, while based on previous studies one would have expected less tolerance from Catholics (Landes, 1998). Active participants in any religion trust the government more than non- religious people, with the only exception of Buddhists. The effect is stronger for Hindus and Muslim, weaker for Catholics and Protestant. Similarly, all religious denominations are associated with a more conservative attitude toward women. However, the effect is much stronger for Muslims.

Judaism has the strongest negative impact on the willingness to cheat on taxes, followed by Protestantism (second), Catholicism and Hinduism (third), and Islam (fourth). The ranking changes somehow when it comes to accept a bribe. The strongest negative effect is for Buddhist, with Protestants and Muslim next, and Catholics last. Protestants are the only religious group that favors incentives. This result vindicates Weber's claims. 
Religious denominations also differ in their attitude toward private ownership. Observant Catholics support private ownership twice as much as Protestants, while Muslims and Hindus are strongly against competition. Finally, with the exception of Buddhists, religious people of all denominations are more inclined to believe that poor people are lazy and lack will power. The effect is stronger for Protestants than Catholics.

Overall, we find that Christian religions are more positively associated with attitudes conducive to economic growth, while religious Muslims are the most antimarket. Within Christian denominations, the ranking is unclear: Protestants are more trusting and favor incentives more, Catholics are more thrifty and favor private property and competition more.

The rest of the paper proceeds as follow. Section I briefly reviews the theoretical priors on the economic effects of religion. Section II presents the dataset we use and our measure of religious affiliation and attitude toward cooperation, government, legal rules, and the market economy. Section III reports the results of the effects of religion in general, while Section IV differentiates across religious denominations. Section V concludes.

\section{Theoretical Predictions}

An excellent survey of the theoretical debate on the links between religion and economic development is provided by Steuart (1998). Without aspiring to be exhaustive, we now summarize the main points of this debate.

The earliest crucial point was the direction of causality. On the one hand, Feuerbach and Marx see religion as a mere reflection of human life. In his Criticism of 
Hegel's Law, Marx (1844) states: "The grounds of the unreligious critique is man made religion, religion does not make man... Religious misery is, by one side, an expression of the real misery. Religion is the exhausted creature's sigh, the state of animus of a heartless world, the spirit of spiritless situations. Religion is the people's opium."

Weber was of the opposite view. In his classic "The Protestant Ethic and the Spirit of Capitalism," Weber attributes the emergence of the spirit of capitalism to the development of a Protestant ethic. Weber's Protestant ethic results from the interaction of the doctrine of salvation and the concept of good works. It was Luther who decisively altered the Christian concept of good works by prescribing the "fulfillment of duties in worldly affairs as the highest form which the moral activity of the individual could assume" (Weber, 1905).

Eisenstadt moves away from an analysis of a direct causal link between Protestantism and capitalism to focus on the "transformative potential" of religions. The transformative potential refers to the "capacity to legitimize, in religious or ideological terms, the development of new motivations, activities, and institutions which were not encompassed by their original impulses and views" Eisenstadt (1968). Eisenstadt's main thesis is that Protestantism redefined political and social institutions, and impacted on the reformulation of roles within the economic sphere.

Eisenstadt's concept of transformative potential is also useful in assessing the potential impact of other religions, such as Hinduism. Given the multiplicity of gods and sects, it is very difficult to identify a clear position of Hinduism toward economic activity. In particular, the stereotype that portrays Hindu as ascetic and uninterested in the material world can be rejected easily. In the Panchatantra we find statements such as 
"wealth gives constant vigor, confidence and power" and "poverty is a curse worse than death" (Uppal, 1986). Nevertheless, according to Eisenstadt, the highly ritualistic behavior promoted by Hinduism is less likely to facilitate the development of more systematic efforts in any field of activity.

We encounter similar problems when we analyze Islam. While the Sunnah prohibits the formation and conclusion of aleatory contracts based on chance (Jomo, 1992), many verses of the Quaran encourage effort and improvement. Thus, the underdevelopment of many Islamic countries cannot be attributed to Islam per se, but is possibly due to the development, somewhere in between the ninth and the eleventh century, of inflexible political and legal institutions in the Islamic world designed to discourage growth values and practices and aimed at preserving the status quo.

More recently, the debate has focused on the impact of religion on specific attitudes that might promote or hamper growth, rather than on differences in the Weltanschauung fostered by different religions. Putnam (1993) for instance, focuses on trust and claims that the Catholic tradition, which emphasizes the vertical bond with the Church rather than a horizontal bond with fellow citizens, has a negative impact on people's average level of trust in others. Landes (1998) focuses on tolerance and claims that the culture of intolerance diffused by the Catholic Inquisition negatively affected the ability of Catholic countries to grow.

We follow this more recent literature in considering religious beliefs as low frequency variables, based on religious teachings, which affect people's attitudes towards the economic system. These religious teachings do not necessarily reflect the authentic message contained in the sacred texts. They simply represent the way certain religion 
beliefs became crystallized over time and the way they are taught and transmitted from one generation to the next. As a result, even if we were willing to interpret in a causal way the negative correlation between attitudes towards private property and the Muslim religion, we do not want to say that this is Mohammed's or the Quaran's fault, but simply the effect of the Muslim cultural tradition and the way it has evolved as a result of historical circumstances.

\section{Existing empirical studies}

In his survey on the economics of religions, Iannaccone (1998) claims that "the most noteworthy feature of the Protestant Ethic thesis is its absence of empirical support." In fact, work by Samuelsson (1993) and Tawney (1926) shows that most of the capitalist institutions described by Weber were antecedent to the Protestant Reformation.

However, this evidence only rejects the specific channel proposed by Weber, not a more general link between the Protestant ethic and the development of a capitalist attitude. In fact, in a cross-country study of former British, French, and Spanish colonies, Grier (1997) shows that Protestantism is correlated positively with growth and development.

To verify or disprove Weber's thesis, however, it is necessary to go past the fact that the Protestant countries have been more successful economically. This was the fact that motivated Weber in the first place, so it cannot be used to test his theory.

Blum and Dudley (2001) make an important step in this direction. First, they refine Weber's thesis. They argue that Protestantism, by rejecting the Catholic sacrament of penance and increasing the individual penalty for defaulting, improved the level of 
mutual trust and cooperation. Second, they use this theory to explain why wages rose in Protestant cities between 1500 and 1750, while at the same time the wages in Catholic cities fell.

The recent literature can be distinguished between macro and micro studies. The macro literature focuses on cross-countries studies. La Porta et al. (1997) and Inglehart (1999) provide evidence in favor of Putnam's argument that Catholic countries have a lower level of trust. Barro and McCleary (2002) find that economic growth responds positively to the extent of religious beliefs, but negatively to church attendance. Finally Stulz and Williamson (2001) claim that countries permeated by Catholic culture, with its traditional anti-usury bent, tend to protect creditors' rights less.

The problem with these studies is that there are too many institutional differences across countries and too few degrees of freedom to identify the specific effects of religions separately. For example, it is impossible to distinguish whether the ultimate effect is due to the country's main religion or to some other characteristics correlated with the beliefs of the dominant religion. Country-fixed effects would solve this identification problem, but they cannot be used in this framework.

At the micro level, there are several studies on the effects of religion on economic outcomes. Religion seems to affect wages (Chiswick, 1983), school attendance (Freeman, 1986), health (Ellison, 1991), and criminal behavior (Evans et al., 1995). Yet, there are problems with these studies. First, there is an issue of endogeneity: "good kids may avoid drugs, stay in school, and go to church" (Freeman, 1986). Thus, it is far from clear that the correlation is causal. Second, these studies are based on a single country (generally the United States). Thus, they can hardly be generalized to other countries. Finally, they 
focus on the correlation between religion and outcomes, not attitudes. Outcomes are the result of attitudes but also of the surrounding environment. For example, ceteris paribus Catholics in the United States tend to have higher wages (not as high as Jews, but higher than other religions). But this success is generally attributed to the quality of their educational system. Thus, it is not necessarily Catholicism per se that makes them more successful in life, but rather the interaction between the educational system and Catholic Church organizations in the United States. It would be very dangerous, therefore, to extrapolate this result to Latin America and to claim for example, that Catholicism would have a positive influence on the standard of living there.

In sum, more than one hundred years after its inception, the debate on the economic effects of religion is far from settled. The complexity and variety of every religion make it impossible to reach any conclusion on purely theoretical grounds. On the other hand, empirical work is plagued by identification problems.

\section{Our Empirical Strategy}

We plan to overcome these problems in the following ways. First, we will control for individual country effects, eliminating the impact of other institutional variables. This approach runs the risk of underestimating the effect of religion to the extent its impact has been absorbed fully in the national culture. ${ }^{1}$ Nevertheless, what we find can be attributed more credibly to religion.

Second, we use religious upbringing to identify the effect of religion that is independent of individual characteristics, particularly those that are unobservable to us.

\footnotetext{
${ }^{1}$ For example, the Italian philosopher Benedetto Croce stated that the Christian tradition has affected the Italian culture so much that Italian cannot be considered non-Christian even if they are atheists.
} 
Third, we reduce the effect of potentially spurious factors by looking at people's attitudes rather than at their economic outcome. Asking somebody his view on cheating on taxes is different from asking him if he has cheated on his taxes. The first question, however, is more appropriate for our purposes than the second. The decision of whether to actually cheat is affected greatly by the probability of being caught. This is a function of a country's law enforcement, not of an individual's attitude. Therefore, looking at attitudes is a better way of identifying the effect of religious beliefs on people's preferences.

In spite of all these improvements, we are well aware of the difficulty in interpreting the observed correlations as causal effects. The traditional latent variable critique (that a latent variable causes people both to be more religious and to behave in a certain way) can be applied even to religious upbringing, as long as we are willing to assume that this latent variable can be transmitted from parents to children (either genetically or through education). For this reason, we prefer to interpret our results as more precisely estimated partial correlations. Even when, to simplify the exposition, we will talk about the "impact" of religion, the reader should interpret this as mere correlation.

We choose as our dependent variables attitudes that might have an important economic impact. Our variables can be grouped into six categories; attitudes toward: 1) trust and cooperation; 2) women; 3) the government; 4) the law; 5) the market and its fairness; 6) thriftiness. We chose the first set of variables because trust and cooperation have been shown to be relevant for economic growth (Knack and Keefer, 1997, Knack and Zak, 2001). Also, Landes (1998) claims that intolerance has negative impact on 
growth. We chose to look at attitudes toward women because of their obvious link with the labor market participation decision and thus with a country's endowment of labor. We looked at attitudes toward the government because political instability has been shown to be detrimental for growth (e.g. Barro, 1991) and investments (e.g. Alesina and Perotti, 1994). Attitudes toward the law are important because they affect a country's law-andorder tradition, which in turn affects financial development (La Porta et al, 1997) and finally growth. One of the variables analyzed here is the attitude toward corruption, which has been shown to be detrimental to growth (Mauro, 1995). Pro-market policies are widely believed to favor growth, and Easton and Walker (1997) provide systematic evidence for this. Finally, we look at attitudes toward thrift not only for historical reasons (Weber attributed the success of Capitalism in certain countries to Protestants'superior thrift), but also because of its importance in the modern theory of growth.

\section{The Data}

\section{Description of the World Value Survey}

The World Values Survey (WVS) is a cross-country project coordinated by the Institute for Social Research of the University of Michigan, under the direction of Ronald Inglehart. Each wave carries out representative national surveys of the basic values and beliefs of individuals in a large cross-section of countries. This questionnaire contains information about demographics (sex, age, education, etc.), self-reported economic characteristics (income, social class), and answers to specific questions about religion, political preferences, and attitudes. 
We use the last three waves that are available (1981-4, 1990-3 and 1995-7). Respondents come from 66 independent countries. These countries include almost 80 percent of the world's population. The coverage of countries varies across surveys. The 1981-3 survey covered 22 independent countries and Northern Ireland; the 1990-3 survey expanded to cover 42 independent countries, Northern Ireland, and greater Moscow; the 1995-7 survey covered 54 independent countries.

Being a large and very complex dataset, the WVS suffers from some coding problems. Even after implementing all the changes suggested by the codebook, we found that a few countries have a distribution of religious denominations that is very different from the one reported in the U.S. Central Intelligence Agency (CIA) factbook. To be on the safe side, we eliminated these country-years. ${ }^{2}$ We might thus be eliminating valid observations for countries where the survey weights are very different from the population weights. Nevertheless, we think this procedure does not introduce any clear bias, while the opposite type of error would.

We were also forced to drop a few countries because of missing data on some other variables that are crucial for our analysis (these countries included Canada, South Korea, Pakistan, China, the Czech Republic and Slovakia). The summary statistics for the remaining countries are presented in Table 1.

\footnotetext{
${ }^{2}$ As a result, we dropped Australia (1,228 obs.) for the 1981 wave; Canada (1,730 obs.) and Nigeria $(1,001$ obs.) for the 1990 wave; Taiwan (1,452 obs.), Nigeria (2,767 obs.), Ghana (95 obs.) and the Philippines (1,200 obs.) for the 1995 wave. Our only doubt was Finland, where the percentage of Protestant was fine, but the percentage of Jews appeared too high. For this reason, we reran all the regressions excluding Finland, without appreciable differences in the results.
} 


\section{Measures of religious affiliation}

Table 1, Panel A, reports summary statistics of the attitudes toward religion by country. The first column reports the percentage of respondents that answered yes to the question "Were you brought up religiously at home?" The second and third column report the answer to the following question "Apart from weddings, funerals, and christenings, about how often do you attend religious services these days?" The fourth column is the percentage of people who answer no to the question "Do you believe in God?"

Table 1, Panel B, reports the distribution of population by religious denomination and country. Religious denomination is coded based on the answers to the following question: "Do you belong to a religious denomination? IF YES: Which one?"

We use the first set of answers to identify the exogenous component of religion, the one that does not depend on individual characteristics. To measure the intensity of religious beliefs, we use the frequency of attendance at religious services, rather than self-declared membership in a religious denomination. Many people who have been raised in a certain religion continue to declare that they belong to that religion even if they attend religious services less than once a year. We do not regard this as additional information with respect to religious upbringing. ${ }^{3}$

Religious denominations differ in the extent to which they prescribe weekly attendance at religious services. Our goal, though, is not to measure adherence to a precept, but rather exposure to religious teachings. Since people who attend religious

\footnotetext{
${ }^{3}$ In several specifications we have tried and used self-declared membership in a religious denomination instead of attendance at religious services at least once a year, as a measure of religious belief. The results were very similar.
} 
services more are exposed to religious principles more, we use church attendance as a proxy for the dimension of religiosity we care about.

Table 1, Panel C, reports the distribution of the intensity of religious beliefs by religious denomination. People who declare themselves Catholic, for instance, attend religious services much more often than people who declare themselves of any other religious denomination except Hindu. In evaluating the potential impact of different religious denominations, we have to take into consideration these systematic differences in the intensity of beliefs.

\section{Our dependent variables}

Table 1, Panel D, reports the summary statistics for our dependent variables. All of them represent measures of people's attitudes. We focus on attitudes that have a direct impact on economic life. We divide them into four groups.

\section{Measures of attitude toward cooperation}

The first group contains measures of people's attitude toward cooperation. Variable 1, which we label trust, is based on the following question: "Generally speaking, would you say that most people can be trusted or that you can't be too careful in dealing with people?" The variable is equal to 1 if participants report that most people can be trusted and zero otherwise. Variables 2 and 3, which we label intolerance toward other races and intolerance toward immigrants, respectively, are based on the following question: "On this list are various groups of people. Could you please sort out any that you would not like to have as neighbors?" (Variable 2: People of a different race; Variable 3: The immigrants). Variable 4, which we label average intolerance, is the 
combination of variables 2 and 3 and is equal to 1 if either variable 2 or 3 is equal to one or if both are.

\section{Measures of attitude toward government}

The second group of variables contains measures of people's attitude toward government institutions. Variables 5, 6, and 7 are based on the following: "I am going to name a number of organizations. For each one, could you tell me how much confidence you have in it: a great deal of confidence, quite a lot of confidence, not very much confidence, or none at all?" The answers are coded 1 to 4 , by increasing degree of confidence. The organizations we considered are the government, the police, and the armed forces.

\section{Measures of attitude toward women}

The third group of variables contains measures of people's attitude toward women. Since we are ultimately interested in the effects on labor participation, we focused on questions that might influence women's propensity to work. Hence, variable 8 is the answer to this question: "When jobs are scarce, should men have more right to a job than women?" Answers are coded 1 to 4; we recoded them so that a higher number represents a higher degree of agreement. Variable 9 comes from the answer to the question: "Do you think that women should have children in order to be fulfilled, or is this not necessary?" The answer needs children is coded as one, the answer not necessary is coded as zero. Variables 10 to 12 come from the answer to the question "For each of the following statements I read out, can you tell me how much you agree with 
each. Do you agree strongly, agree, disagree, or disagree strongly?" The statements are: "Being a housewife is just as fulfilling as working for pay" (variable 10); "Both the husband and wife should contribute to household income" (variable 11); "A university education is more important for a boy than for a girl" (variable 12). We recoded them so that a higher number represents a higher degree of agreement.

Measures of attitude toward legal norms

The fourth group of variables contains measures of people's attitude toward legal norms. Variable 13 is based on a question similar to variables 5 to 7 , except that the organization mentioned is the legal system. Answers are coded 1 to 4; we recoded them so that a higher number represents a higher degree of confidence. Variables 14 to 18 are based on the following question: "Please tell me for each of the following statements whether you think it can always be justified, never be justified, or something in between, using this card." Answers are in the range 1-10, with $1=$ never justifiable and $10=$ always justifiable.

The questions we are interested in are: "Claiming government benefits to which you are not entitled" (var. 14); "Avoiding a fare on public transport" (var. 15); "Cheating on taxes if you have a chance" (var. 16); "Buying something you knew was stolen" (var. 17); "Accepting a bribe in the course of their duties" (var. 18).

Measures of attitude toward the market

The fifth group contains measures of people's attitude toward the market (variables 19-21). They are based on the following question: "Now I'd like you to tell me 
your views on various issues. How would you place your views on this scale? 1 means you agree completely with the statement on the left; 10 means you agree completely with the statement on the right; and if your views fall somewhere in between, you can choose any number in between." The statement on the left is normally the opposite of the statement on the right. The statements considered are (reporting only the statements on the right): "We need larger income differences as incentives for individual effort" (var. 19); "Private ownership of business and industry should be increased" (var. 20); "Competition is good. It stimulates people to work hard and develop new ideas" (var.21).

Measures of attitude toward the thriftiness and fairness of the market

As measure of attitude toward thriftiness, we use the answer to the question: Here is a list of qualities that children can be encouraged to learn at home. Which, if any, do you consider to be especially important? We code a 1 if the respondent lists as important "Thrift, saving money and things". 4

Variables from 23 to 25 are questions framed as are variables 19 to 21 , except that the statements are: "People should take more responsibility to provide for themselves" (var. 23); "In the long run hard work usually brings a better life" (var. 24); "Wealth can grow so there is enough for everybody" (var.25).

Finally, variable 26 is based on the question: "Why, in your opinion, are there people in this country who live in need? Here are two opinions: Which comes closest to you view? We code as 1 the answer "They are poor because of laziness and lack of will power" and zero the answer "They are poor because society treats them unfairly."

\footnotetext{
${ }^{4}$ The interviewed person is presented with a list of eleven alternatives, ranging from imagination to obedience, and can mention at most five as important.
} 


\section{Other control variables}

To isolate the effect of religion from other confounding effects, we control for country fixed effects and several individual characteristics. This strategy might underestimate the impact of religion, since religion positively affects health (Ellison, 1991, Levin, 1994 and Levin and Vanderpool, 1987), and income (Chiswick, 1983). Nevertheless, we think it is important to establish whether religion has an additional direct effect.

Table 1, Panel E, reports the demographic characteristics of the respondents. "Health" is coded based on the question: "All in all, how would you describe your state of health these days?" (1=Very poor; 2=Poor, 3=Fair, 4=Good, 5=Very good). "Male" is an indicator variable equal to one if the respondent is male, otherwise it is zero. "Age" is expressed in years. "Education" is the age in years at which the respondent completed his or her highest education (excluding apprenticeships). "Social class" is coded based on the response to the question: "People sometimes describe themselves as belonging to the working class, the middle class, or the upper or lower class. Would you describe yourself as belonging to the: 1=Lower class, 2=Working class, 3=Lower middle class, $4=U$ pper middle class, $5=$ Upper class."

"Income" is coded based on the response to the question: "Here is a scale of incomes. We would like to know in what group your household is, counting all wages, salaries, pensions, and other income that comes in. Just give the letter of the group your household falls into, before taxes and other deductions" (income categories are coded by decile for each society, $1=$ lowest decile, $10=$ highest decile). 


\section{The Impact of Religion}

In Table 2 we present our results on the overall effects of religion. Each attitude is regressed on our four indicators of religiosity - atheists, people brought up religiously, currently religious, and actively religious - some control variables, country specific effects, and calendar year dummies. The size of the reference sample differs across regressions; valid observations vary according to specific questions on individual attitudes, and range from 52,252 to 95,739 .

\section{Control variables}

Before we comment on the results on the impact of religion, it is useful to discuss the effect of our control variables. The results, which are of independent interest, are very reasonable and provide credibility to the measures of attitude we are going to use.

First, health has a strong positive impact on all attitudes. Healthier people trust other people more, are more tolerant, trust the government and the police more, have a more progressive attitude toward women, are less likely to break legal norms, and believe more in markets. The only exception is that healthier people view thrift as less of a value (perhaps because, being healthy, they appreciate the benefits of precautionary saving less). All of these results are statistically significant. From a quantitative point of view, the strongest impact is on trust toward others; an improvement in the health status from "fair" to "very good" increases the average level by 27 percent. In intolerance toward immigrants, the same increase in health reduces the level of intolerance by 12 percent.

Gender also plays a role in some, but not all, attitudes. Males tend to be more intolerant, to trust the government and the armed forces more (but not the police), to be 
more likely to break legal norms, and to be more in favor of markets. Not surprisingly, their attitude toward women is less progressive than that of women themselves.

Older people tend to trust others more, perhaps reflecting a cohort effect, but they are also more intolerant and less progressive toward women. They trust government institutions more, and they are less likely to break the law. Their attitude toward markets, however, is more mixed. Older people lean more toward equality in the equality versus incentives trade off and are less enthusiastic about an increase in private ownership. On the other hand, they believe more in individual (instead of government) responsibility, they believe more that competition is good, and that hard work improves life. They also have more confidence that wealth can grow so that there is enough for everyone.

Education increases trust toward others, reduces intolerance, and improves attitude toward women, but it does decrease the level of trust in government institutions. Education tends to reduce the willingness to break legal norms, but the effect is not always there. For example, more educated individuals seem to be more willing to cheat on taxes (although this effect is not statistically significant) and more willing to avoid paying the fare on public transport. Education also seems to improve attitude toward the market, but to decrease thriftiness and the conviction that the market outcome is fair. More educated people are more willing to believe that success is a matter of luck and connections rather than hard work and less willing to believe that the poor are such because they are lazy.

A higher (self-perceived) social status is associated with more trust toward others, but also more intolerance. Its impact on trust toward government institutions is mixed and tends not to be significant. A higher (self-perceived) social status also is associated with 
a lower willingness to break legal norms and with a higher acceptance of market principles.

Finally, higher income has similar effects to higher social status but with a few interesting exceptions. Higher income people have more progressive attitudes toward women, although they perceive that the wife has less of a duty to contribute to household income. Higher income people are more (rather than less) tolerant, but trust government institutions less. In general they are less willing to break legal norms, but there are two important exceptions: they are more willing to cheat on taxes and more willing to justify a bribe.

In summary, while these controls are difficult to interpret because they may be reflecting several effects, their sign conforms to some intuitive priors, and this reassures us that the attitudes we are focusing on are correctly picking up what they are meant to measure.

\section{The average impact of religiosity}

Table 2 also contains our estimates for the impact of different levels of religiosity. The excluded group is made up of non-religious people, who are not openly atheist. The effects should be read cumulatively. Hence, the trust of somebody who has been raised religiously and attends service at least once a week (and thus also at least once a month) can be obtained by adding the coefficients for our three indicators of religiosity. For this reason, we also report the cumulative effects at the bottom of the table.

We find that on average religion is good for the development of stronger institutions. Religious people trust others more, trust the government more, are less 
willing to break the law, and believe more in the fairness of the market, but they are more intolerant and they have less progressive attitudes toward women.

In general, convinced atheists behave in the opposite way from religious people: they are more tolerant, less trusting of the government and the police, have more progressive attitudes toward women, trust the legal system less, are more willing to break the law, and have worse attitudes toward the market and its perceived fairness. The only exception is that atheists tend to trust other people more. These effects are not simply attributable to the attitudes of Communists in the former socialist countries. Excluding former socialist countries from the sample yields similar results (not reported).

Interestingly, the aspect of religion that seems to matter is different for the various attitudes. "Trust toward others" is affected mostly by religious participation, not by being brought up religiously. This could be because this effect is entirely spurious (good people trust others more and they attend church) or that the dominant aspect is socialization at the service, rather than religious upbringing. By contrast, intolerance is mostly (but not uniquely) an outcome of being raised religiously. Active churchgoers are not more intolerant toward immigrants than the rest of the population (but not less either). Finally, both a religious upbringing and active religious participation increase trust toward government institutions. Similarly, the more conservative attitude of religious people toward women is not associated with religious upbringing: the more a person participates in religious services, the more his attitude toward women is conservative.

Not surprisingly, religious upbringing and affiliation are associated with a reduced willingness to break any sort of legal rule. It is important to stress that this result is also present for religious upbringing alone, which is a sign that this is not just the result 
of a spurious correlation between unobserved individual characteristics, religiosity, and attitude toward legal norms.

The correlation between religiosity and attitudes toward the market is more complex. People raised religiously are less willing to trade off equality for incentives and are less in favor of private property. The correlation changes sign, however, when it comes to people attending religious services on a more regular basis: they are more willing to trade off equality for incentives and in particular, they favor more private ownership.

By contrast, religiosity is associated with a higher emphasis on thrift, a greater sense of individual responsibility, and a stronger belief that the market outcome is fair. Interestingly, religious people are more likely to believe that people are in need because they are lazy and lack willpower rather than because society treats them unfairly. Overall, religious people tend to be more supportive of markets.

The effect of religious upbringing is particularly interesting in light of the identification problem that plagues all the studies on the effects of religion. Any "effect" of religion might be spurious because of some underlying characteristics that shape both religious behavior and the attitudes we focus on. This is the case for example, when we analyze the relationship between attendance to service and attitudes toward women. Being raised religiously, however, is not a choice and cannot be attributed to individual characteristics. It is still possible, though, that religious upbringing might be correlated with some latent characteristics of the parents, which affect children's attitudes directly and not through religious education. 
Therefore, even when we use religious upbringing, we cannot exclude the possibility that a latent variable might drive both religiosity and people's attitudes. For each individual attitude, it is easy to imagine such a variable. For example, individual (or parents) sociability can easily explain both religious attendance (upbringing) and level of trust toward other people. Nevertheless, it is difficult to imagine the same latent variable explaining all the dependent variables. If more social people are more trusting, how do we explain that they are also more intolerant? One would need several latent variables, all positively correlated, to explain all of our facts. At this point, Occam's razor should lead us to accept a causal interpretation of our results.

Yet, even if the observed correlations were driven entirely by unobserved individual characteristics, we still think it is interesting to show that the characteristics that make somebody attend religious services on a regular basis also make her more intolerant toward immigrants and people of other races. Even if religious people are more intolerant because of personal characteristics, it is hard to imagine that a community that attracts the intolerant would not breed further intolerance.

\section{Does the impact differ if a religion is dominant?}

Before probing into the differences between religions, we want to distinguish the effect of religiosity from the effect of adhering to a country's dominant religion. A dominant religion often becomes enmeshed with the national culture and transmitted from generation to generation, not necessarily because of some deep convictions but by force of habit. Thus, being raised religiously and attending the services of the country's dominant religion might mean very different things from being raised religiously and attending the services of a minority religion. 
For this reason, we separately control for the effect of being raised in and being affiliated with the dominant religion (defined as the religion with the highest number of affilates). ${ }^{5}$ The results are reported in Table 3 .

Overall, the impact of religiosity seems to be smaller when this is the dominant religion, but there are important differences. For example, we noted earlier that being raised religiously had a small effect on trust toward others. It turns out that this weak result is the combination of two strong but opposite effects. Somebody raised religiously tends to trust others more, if the religion is not the dominant one. Religious upbringing in the dominant religion is associated with a reduced trust toward others. By contrast, most of the correlation between religion and intolerance is attributable to dominant religions. Similarly, most of the effect of religious upbringing on the attitude toward the police and the armed forces is attributable to being raised in the dominant religion. The effect is negative when somebody is raised in another religion.

The anti-women bias associated with religious education is entirely associated with the dominant religion. By contrast, regular churchgoers are relatively less conservative toward women if they belong to the dominant religion. Similarly, regular attendance at religious services has a less negative impact on the willingness to break legal norms when a person attends the services of the dominant religion. We interpret these results as suggesting that regular attendance at religious services is less an indicator of true religious beliefs when the religion is the dominant one.

When it comes to attitudes toward the market, the differential impact of religiosity in the dominant religion is mixed. The dominant religion tends to increase the effect of being raised religiously on the attitude toward the market and the fairness of its

\footnotetext{
${ }^{5}$ For this definition we use the CIA Factbook.
} 
outcomes, but reduces the impact of service attendance, again consistent with this being less a sign of strong religious beliefs.

\section{The Impact of Different Religions}

Thus far we have only provided evidence that religiosity matters in general. Most of the debate in the literature, however, is not about the effects of religion per se, but the effects of different religions. We deal with this in Table 4.

For those people who claim to belong to a specific religious denomination, Table 4 differentiates the effect of being raised religiously, attending religious services at least once a year, and attending services at least once a month, for the six major religious denominations: Catholics, Protestants, Jews, Muslims, Hindus, and Buddhists. Unfortunately, the questionnaires do not treat Eastern Orthodox consistently (in two of the three surveys they are mixed with "others religious denominations"), so we do not have a separate category for them. For reasons of space we select a subset of variables for each of the four types of attitudes we study. ${ }^{6}$

Religious upbringing has a negative and statistically significant impact on trust for Catholics, Muslims, and Hindus. In all other religions the effect is null. By contrast, in all religions a higher attendance at religious services is associated with a higher level of trust toward others. The only exception is Hinduism. To compare the overall effect of religion, the last two columns of Table 4 report the total. The next to last column shows

\footnotetext{
${ }^{6}$ These are: general trust and intolerance toward others (as representative of attitudes toward cooperation); trust the government (for attitudes toward the government and other institutions); trust the legal system, cheating on taxes and accepting a bribe (for attitudes toward legal rules); men deserve scarce jobs and university education, respectively, more than women (as representative of opinions toward women); income inequality as providing incentives, opinions about increasing private ownership, and judgement about competition (as representative of attitudes toward the market) and teaching thriftiness to children and
} 
the total impact on trust of a person who attends a religious service at least once a week. Since the incidence of churchgoers differs across religious denominations, these figures do not represent a true average impact of a specific religious denomination. Hence, in the last column of table 4 we weigh the impact of the different level of religiosity by the denomination-specific level of religiosity. Most of the time the two numbers tell the same story, but we point out important exceptions.

Overall, Christian religions foster trust, but more so for Protestants. Because the sign is opposite when we focus on religious upbringing, we should be suspicious that the effect is spurious. On the other hand, the fact that it is not present for every religion is evidence against a purely spurious effect. Why would more trusting people attend religious services more often if they are Catholics or Protestants, but not if they are Jews or Muslims? At the very least, we should admit that there is something specific to these religions (and not to the others) that attracts more trusting people. The "impact" of being Protestant is almost twice as large as that of being Catholic, and this difference is statistically significant. In turn, Catholicism breeds trust more than any other nonChristian religion. The only caveat for Jews is that the sample does not include Israel, so all the Jews are minorities living in countries dominated by people of different religious denominations. Thus, this difference might reflect the discrimination to which they are subject.

The relation between religion and intolerance seems to be present in all religious denominations, both for religious upbringing and for attendance at religious services. Only Buddhists are more tolerant. The point estimates for Protestants and Catholics are

believing the poor are so because are lazy (as representative of opinions about thriftiness and the fairness of markets). 
very similar, while those of Muslims are much higher, and those of Hindus even higher. Actively religious Hindus are 29 percent more intolerant than non-religious people, Muslims 19 percent, actively religious Protestant and Catholics 7 percent more.

Religious upbringing increases trust in the government for Muslims and to a lesser extent, for Hindus. Religious participation increases trust in the government for all religious denominations except Buddhists. The effect is stronger for Hindus and Muslims, weaker for Catholics and Protestants.

As Panels D and E show, all religious denominations are associated with a more conservative attitude toward women. However, that effect is twice as strong for Muslims than for any other religion.

Similarly, all religions result in increased trust in the legal system and reduced willingness to break legal rules; however, the effect differs significantly across religious denominations. Judaism has the strongest negative impact on willingness to cheat on taxes, Protestantism second, Catholicism and Hinduism third, and Islam fourth. The rankings are different when it comes to accepting a bribe. The strongest negative impact comes from Buddhism, with Protestants and Muslims next, and Catholics last.

Religions differ most in their position on the trade off between equality and incentives. Protestants and Hindus are more willing to trade off equality for incentives, while Jews and Muslims are less so. For the other religions, the effect is insignificant.

Religious denominations also differ in their attitudes toward private ownership. Protestants, Catholics, and Hindus want more private ownership, while Muslims want significantly less private ownership. Interestingly, Catholics support private ownership twice as much as Protestants (and the difference is statistically significant at the 10 
percent level). Catholics also are more in favor of competition than any other religious group (including Protestants), while religious Muslims and Hindus are strongly against competition.

Only Catholics believe strongly that thrift is a value to be taught to children. Among Protestants, only those who attend religious services just once a year share this conviction. Regular churchgoers are less likely to include thrift as a value to be taught to children. This is somewhat at odds with Weber's claim that the Protestant religion has favored the development of capitalism through its emphasis on thrift.

Finally, religious people of all denominations (except Buddhists) are more inclined to believe that people in need are lazy and lack will power. The effect is somewhat stronger for Protestants than for Catholics.

Does the impact differ if a religion is a minority?

Table 5 reports the results obtained by dividing the sample on the basis of the dominant religion (as reported in the CIA Factbook). For space considerations, we only report the results with the three main religions: Catholicism, Protestantism, and Islam.

In Catholic-dominated countries, religions have a less positive impact on trust toward others for all religious denominations, including Catholics themselves. Not surprisingly, religions tend to increase intolerance only when they are dominant. Thus, Catholics are more intolerant in Catholic countries, but not in Protestant countries; Protestants are more intolerant in Protestant countries, but not in Catholic ones. An interesting result comes from panel C: religious Jews trust the government less in a Catholic-dominated country, while they trust it significantly more in Protestant- 
dominated countries. This result can be explained easily in light of the strong antiSemitism historically present in the Catholic Church's tradition, as reflected in the way that Jews were treated in the Papal state. ${ }^{7}$

The relationship between religiosity and other attitudes does not seem to be affected greatly by what the dominant religion is.

\section{Has the Impact of Catholicism Changed?}

The aggregate-level evidence suggests the Catholic religion has a negative effect on trust (La Porta et al, 1997, Inglehart, 1999) and institutions (La Porta et al., 1999). In the micro data we find some evidence for the first, but very little evidence for the second. One possibility is that these characteristics are not specific to Catholicism, but rather come from other dimensions of the culture in the regions where Catholicism is prevalent (mainly Southern European countries and their former colonies). Alternatively, these qualities may have been specific to Catholicism, but they have changed since the reforms introduced by the Second Vatican Council. In this latter case, they would simply survive as a cultural aspect of countries imbued with Catholic culture, but not in the Catholic people.

To try to separate these two effects we re-run the regressions described in Table 4, splitting the sample based on the age of the respondent. The Second Vatican Council, which took place in 1962, substantially changed Catholic doctrine and teaching. Not only was the use of Latin in the Mass abolished, but also there was an opening up of dialogue with the other religious denominations. As a result, Catholics after 1960 received a very different education from their older peers. If these changes indeed affected the influence

\footnotetext{
${ }^{7}$ For example, the yellow star used by the Nazis to single out the Jews was first introduced and used in the
} 
of Catholicism, we should see a difference in the effect of Catholicism on the older versus the younger generation. To control for generic cohort differences in Table 6, we insert a dummy for people born after 1960 into the basic regression and then interact this dummy with the different levels of religiosity of Catholics.

We find that Catholics raised after Vatican II are more trusting of other people and less intolerant. Their religious upbringing and practice also have less of a negative effect on women's rights. Interestingly, Vatican II does not seem to have caused a relaxation in moral values. While the younger cohort on average is more likely to break legal norms, Catholics raised after Vatican II are less likely to break legal norms than older Catholics (panel C). By contrast, Catholics raised after Vatican II are less promarket (panel C). They believe less in private property and competition. They value thrift more, but they are more willing to believe that people are poor because of some injustice in society. These results overall provide some preliminary evidence in favor of the hypothesis that the negative impact of Catholicism found in the previous literature may be explained by some cultural characteristics that survive in countries imbued with Catholic culture, but do not exist anymore in Catholic people. More research is needed to investigate this hypothesis further. In the meantime, we can conclude that Catholicism today is not a significant obstacle to economic development.

\section{Conclusions}

In our analysis of the effect of religion on people's attitudes toward cooperation, government, women, legal rules, the market economy, and thriftiness we have found a remarkable number of regularities. We found on average that religion is good for the

Vatican State (Kertzer, 2001). 
development of attitudes that are conducive to economic growth. But this statement needs to be qualified.

First, religious people are more intolerant and have more conservative views of the role of women in society. Second, these correlations differ depending on whether a specific religious denomination dominates in a country. Third, these correlations differ across religious denominations.

Since Weber the previous literature on the effects of religions on growth has tried to "rank" religions or at least highlight characteristics in some religious denominations that would make them more conducive for economic growth than others. If we try to do the same with our results, the ranking would not be consistent across attitudes. On average, Christian religions are more positively associated with attitudes that are conducive to economic growth, while Islam is negatively associated. The ranking between the two main Christian denominations is less clear. Protestants trust others and the legal system more than Catholics and they are less willing to cheat on taxes and accept a bribe with respect to Catholics. By contrast, Catholics support private ownership twice as much as Protestants and are more in favor of competition than any other religious group (including Protestants). The only case in which Protestants seem more pro-market than Catholics is on incentives. When asked whether they are willing to accept more income inequality to provide incentives Protestants and Hindus are the only religious groups that favor incentives. This result is consistent with Weber's view.

From these results, however, we cannot conclude which religion is better for growth. In order to answer this question two further steps are necessary. First, we need to investigate the relative importance of the attitudes studied for economic growth. Second, 
we need to make a stronger case that the statistical relations observed are causal. Further research is needed. 


\section{References}

Alesina, Alberto, and Roberto Perotti, 1995, Taxation and Redistribution in an Open Economy, European Economic Review 39, 961-79.

Barro, Robert J., 1991, Economic Growth in a Cross Section of Countries, Quarterly Journal of Economics, May, 407-443.

Barro, Robert J. and Rachel M. McCleary, 2002, Religion and Political Economy in an International Panel, manuscript, Harvard University.

Blum, Ulrich and Leonard Dudley, 2001, Religion and economic growth: was Weber right?, Journal of Evolutionary Economics, 11(2): 207-230.

Chiswick, Barry R., 1983, The Earnings and Human Capital of American Jews, Journal of Human Resources, 18 (3): 313-36.

Easton, Stephen T. and Michael A. Walker, 1997, Income, Growth, and Economic Freedom, American Economic Review 87(2): 328-32.

Eisenstadt, Shmuel Noah, 1968, The Protestant Ethic and Modernization: A Comparative View. New York, Basic Books.

Ellison, Christopher G., 1991, Religious Involvement and Subjective Well-being, Journal of Health \& Social Behavior, 32(1): 80-99.

Evans, T. David et al., 1995, Religion and Crime Reexamined: The Impact of Religion, Secular Controls, and Social Ecology on Adult Criminality, Criminology, 33(2):195-224.

Freeman, Richard B., 1986, Who Escapes? The Relation of Churchgoing and Other Background Factors to the Socioeconomic Performance of Black Male Youths from Inner-city Tracts, in: Richard B. Freeman and Harry J. Holzer, eds,. The Black Youth Employment Crisis Chicago and London: U. Chicago Press, 353-76.

Grier, Robin, 1997, The Effect of Religion on Economic Development: A Cross-National Study of 63 Former Colonies, Kyklos, 50(1): 47-62.

Iannaccone, Laurence R., 1998, Introduction to the Economics of Religion, Journal of Economic Literature, 36(3): 1465-1496.

Inglehart Ronald, 1999, Trust, well-being and democracy in: Mark Warren, ed., Democracy and Trust, New York and Cambridge: Cambridge Univ. Press, 88-120.

Jomo, K.S., 1992, Islam and Capitalist Development: A Critique of Rodinson and Weber, in: K.S. Jomo,ed., Islamic Economic Alternatives,. London, Macmillan. 
Kertzer David, I, 2001, The Popes Against the Jews: The Vatican's Role in the Rise of Modern Anti-Semitism, Random House.

Knack, Stephen, and Philip Keefer, 1997, Does Social Capital Have an Economic Payoff? A Cross-Country Investigation, Quarterly Journal of Economics 112(4): 125188.

Knack, Stephen and Paul J. Zak, 2001, Trust and Growth, Economic Journal 111(470): 295-321.

La Porta, Rafael, Florencio Lopez-de-Silanes, Andrei Shleifer, and Robert W. Vishny, 1997, Trust in large organizations, American Economic Review, 87(2): 333-338.

La Porta, Rafael, Florencio Lopez-de-Silanes, Andrei Shleifer, and Robert W. Vishny, 1999, The Quality of Government, Journal of Law Economics \& Organization. 15 (1): 222-79.

Landes, David, 1998, The Wealth and Poverty of Nations, London: Little, Brown, and Company.

Lessnoff, M.H., 1994, The Spirit of Capitalism and the Protestant Ethnic: An Enquiry into the Weber Thesis. Aldershot, Edward Elgar.

Levin, Jeffery S., 1994, Religion and Health: Is There an Association, Is It Valid, and Is It Causal?, Social Science Medical Journal, 38(11): 1475-82.

Levin, Jeffrey S. and Harold Y. Vanderpool, 1987, Is Frequent Religious Attendance Really Conducive to Better Health? Toward and Epidemiology of Religion, Social Science Medical Journal, 24(7): 589-600.

Mauro, Paolo, 1995, Corruption and Growth, Quarterly Journal of Economics 110(3): 681-712.

Marx, Karl, 1844, Contribution to the Critique of Hegel's Philosophy of Law, Published in the Deutsch Französische Jahrbücher.

Putnam, Robert, 1993, Making Democracy Work. Civic Traditions in Modern Italy, Princeton, Princeton University Press.

Samuelsson, Kurt, 1993, Religion ad Economic Action: The Protestant Ethic, the Rise of Capitalism, and the Abuses of Scholarship. Toronto: U. Toronto Press.

Steuart, Ian, 1998, An Investigation into the Relationship between Religion and Economic Development, manuscript. 
Stulz, Renee and Rohan Williamson, 2001, "Culture, Openness and Finance," NBER working paper 8222 .

Tawney, Richard H., 1926, Religion and the Rise of Capitalism. New York: Harper and Row.

Uppal, J.S., 1986, "Hinduism and Economic Development in South Asia," International Journal of Social Economics, 13(3):20-33.

Weber, Max, 1905, 1956, The Protestant Ethic and The Spirit of Capitalism. London, Unwin. 


\section{Table 1: Sample Statistics}

This table reports sample statistics of the responses from WORLD VALUES SURVEY 19811984, 1990-93 and 1995-97 (ICPSR 2790). Respondents were from 66 independent countries in at least one wave. These countries include almost 80 percent of the world's population. The coverage of countries varies across surveys. The 1981-83 survey covered 22 independent countries plus Northern Ireland; the 1990-93 survey covered 42 independent countries plus Northern Ireland, and Greater Moscow; the 1995-97 survey covered 54 independent countries.

Panel A reports summary statistics of religious beliefs by country. The first column reports the percentage of respondents that answered yes to the question "Were you brought up religiously at home?" The second and the third column reports the answer to the following question "Apart from weddings, funerals and christenings, about how often do you attend religious services these days?". The fourth column is the percentage of people who answer no to the question "Do you believe in God?"

Panel B reports distribution of population by religious denomination and country. Religious denomination is coded based on the answers to the following question: "Do you belong to a religious denomination? IF YES: Which one?"

Panel C reports summary statistics of the intensity of religious beliefs by religious denomination.

Panel D reports summary statistics for the variables used in the regression analysis. Variable 1 is based on the following question: "Generally speaking, would you say that most people can be trusted or that you can't be too careful in dealing with people? The variable is equal to 1 if participants report that most people can be trusted and zero otherwise. Variables 2 and 3 are based on the following question: "On this list are various groups of people. Could you please sort out any that you would not like to have as neighbors?" (Variable 2: People of a different race; Variable 3: The immigrants). Variable 4 is the combination of variables 2 and 3 and is equal to 1 if either variable 2 or 3 or both is equal to one. Variables 5, 6 and 7 are based on the general question: I am going to name a number of organizations. For each one, could you tell me how much confidence you have in them: is it a great deal of confidence, quite a lot of confidence, not very much confidence or none at all? Answers are coded 1-4, we recoded them so that a higher number represents a higher degree of confidence. Organizations we considered are the government, the police and the armed forces. Variables 8 comes from the answers to the question Do you agree or disagree with the following statement: When jobs are scarce, men should have more right to a job than women? Answers are coded 1-4, we recoded them so that a higher number represents a higher degree of agreement. Variables 9 comes from the answers to the question: Do you think that women should have children in order to be fulfilled or is this not necessary? The answer needs children is coded as one, the answer not necessary is coded as a zero. Variables 10-12 come from the answer to the question For each of the following statements I read out, can you tell me how much you agree with each. Do you agree strongly, agree, disagree, or disagree strongly? The statements are: Being a housewife is just as fulfilling as working for pay (variable 10), Both the husband and wife should contribute to household income (variable 11), A university education is more important for a boy than for a girl (variable 12). We recoded them so that a higher number represents a higher degree of agreement. Variable 13 is based on a question similar to variables 5 to 7, except that the organization mentioned is the legal system. Answers are coded 1-4, we recoded them so that a higher number represents a higher degree of confidence. Variables 14 to 18 are based on the following question: "Please tell me for 
each of the following statements whether you think it can always be justified, never be justified, or something in between, using this card." Answers are in the range 1-10, with $1=$ never justifiable and $10=$ always be justifiable. "Claiming government benefits to which you are not entitled" (var. 14). "Avoiding a fare on public transport" (var. 15). "Cheating on taxes if you have a chance" (var. 16). "Buying something you knew was stolen" (var. 17). "Accepting a bribe in the course of their duties" (var. 18). Variables 19-21 and 23 to 26 are based on the following question: Now I'd like you to tell me your views on various issues. How would you place your views on this scale? 1 means you agree completely with the statement on the left; 10 means you agree completely with the statement on the right; and if your views fall somewhere in between, you can choose any number in between. The statement on the left is normally the opposite of the statement on the right. Statements considered are (we report only statement on the right): We need larger income differences as incentives for individual effort" (var. 19); "Private ownership of business and industry should be increased" (var. 20); "Competition is good. It stimulates to work hard and develop new ideas" (var.21); People should take more responsibility to provide for themselves (var. 23); "In the long run hard work usually brings a better life" (var. 24); "Wealth can grow so there is enough for everybody" (var.25). Variable 22 is based on the answer to the question Here is a list of qualities that children can be encouraged to learn at home. Which, if any, do you consider to be especially important? We code as 1 if the respondent list as important "Thrift, saving money and things". Variable 26 is based on the question: Why, in your opinion, are there people in this country who live in need? Here are two opinions: Which comes closest to you view? We code as one the answer "They are poor because of laziness and lack of will power" and zero the answer "They are poor because society treats them unfairly".

Panel E reports the demographic characteristics of the respondents. "Health" is coded based on the question: "All in all, how would you describe your state of health these days? $(1=$ Very poor; $2=$ =Poor, 3=Fair, 4=Good, 5=Very good)". "Male" is an indicator variable equal to one if the respondent is male, otherwise equal to zero. "Age" is expressed in years. "Education" is the age in years at which the respondent completed his or her highest education (excluding apprenticeships). "Social class" is coded based on the response to the question: "People sometimes describe themselves as belonging to the working class, the middle class, or the upper or lower class. Would you describe yourself as belonging to the: $1=$ Lower class, $2=$ Working class, $3=$ Lower middle class, $4=$ Upper middle class, 5=Upper class". "Income" is coded based on the response to the question: "Here is a scale of incomes. We would like to know in what group your household is, counting all wages, salaries, pensions and other incomes that come in. Just give the letter of the group your household falls into, before taxes and other deductions" (income categories are coded by decile for each society, 1=lowest decile, 10=highest decile). 
Panel A: Attitudes towards religion by country (percentages)

\begin{tabular}{|c|c|c|c|c|c|}
\hline Country & $\begin{array}{l}\text { Raised religiously } \\
\text { at home }\end{array}$ & $\begin{array}{l}\text { Goes to church } \\
\text { at least once a } \\
\text { year }\end{array}$ & $\begin{array}{l}\text { Goes to church } \\
\text { at least once a } \\
\text { week }\end{array}$ & $\begin{array}{l}\text { Do not believe } \\
\text { in God }\end{array}$ & $\begin{array}{l}\text { Number } \\
\text { of } \\
\text { respondents }\end{array}$ \\
\hline France & 32.38 & 37.1 & 10.4 & 33.02 & 2202 \\
\hline Britain & 23.84 & 30.38 & 9.95 & 12.92 & 3808 \\
\hline West Ger & 43.3 & 56.34 & 16.98 & 19.35 & 4423 \\
\hline Italy & 56 & 76.86 & 35.44 & 10.07 & 3366 \\
\hline Netherlands & 32.57 & 53.22 & 22.79 & 29.54 & 2238 \\
\hline Denmark & 19.8 & 42.68 & 2.67 & 31.65 & 2212 \\
\hline Belgium & 60.12 & 51.21 & 27.53 & 22.28 & 3937 \\
\hline Spain & 75.33 & 57.9 & 29.64 & 11.59 & 13370 \\
\hline Ireland & 42.44 & 93.73 & 81.46 & 2.75 & 2217 \\
\hline N. Ireland & 41.4 & 81.33 & 50.65 & 3.25 & 616 \\
\hline U.S.A. & 48.28 & 74.57 & 43.27 & 3.21 & 5706 \\
\hline Japan & 14.26 & 71.06 & 3.06 & 25.45 & 3269 \\
\hline Mexico & 50.57 & 82.06 & 48.22 & 4.47 & 4878 \\
\hline S. Africa & 68.52 & 48.78 & 31.94 & 1.6 & 7267 \\
\hline Hungary & 27.97 & 43.32 & 12.38 & 33.17 & 2463 \\
\hline Australia & 64.06 & 46.34 & 16.5 & 18.65 & 2048 \\
\hline Norway & 28.27 & 47.98 & 5.07 & 28.74 & 3612 \\
\hline Sweden & 21.13 & 37.77 & 4.55 & 39.44 & 3010 \\
\hline Iceland & 32.29 & 53.22 & 2.33 & 16.94 & 1629 \\
\hline Argentina & 54.8 & 59.88 & 22.59 & 7.58 & 3086 \\
\hline Finland & 29.44 & 53.41 & 3.65 & 10.82 & 2578 \\
\hline Poland & 96.84 & 92.35 & 59.92 & 1.48 & 2091 \\
\hline Switzerland & 68.26 & 58.23 & 18.91 & 6.74 & 2612 \\
\hline Puerto Rico & 86.77 & 81.19 & 51.55 & 0.69 & 1164 \\
\hline Brazil & 76.08 & 68.41 & 34.63 & 1.26 & 2931 \\
\hline Chile & 79.92 & 63.96 & 26.64 & 3.76 & 2500 \\
\hline Belarus & 25.65 & 46.77 & 4.83 & 29.03 & 3107 \\
\hline India & 91.39 & 89.27 & 49.1 & 5.99 & 4540 \\
\hline East Ger & 43.71 & 34.88 & 9.68 & 62.22 & 2345 \\
\hline Slovenia & 72.82 & 63.61 & 22.43 & 33.3 & 2042 \\
\hline Bulgaria & 39.55 & 44.73 & 6.32 & 41.12 & 2106 \\
\hline Romania & 76.97 & 85.4 & 18.59 & 5.98 & 1103 \\
\hline Portugal & 83.8 & 59.92 & 39.07 & 10.04 & 1185 \\
\hline Austria & 82.05 & 67.67 & 25.41 & 11.92 & 1460 \\
\hline Turkey & 60.64 & 54.68 & 32.41 & 1.23 & 2937 \\
\hline Lithuania & 68.09 & 38.43 & 7.77 & 5.97 & 2009 \\
\hline Latvia & 27.58 & 44.56 & 3.38 & 19.26 & 2103 \\
\hline Estonia & 16.07 & 25.33 & 1.82 & 21.49 & 2029 \\
\hline Ukraine & 30.74 & 54.46 & 9.82 & 19.85 & 2811 \\
\hline Russia & 15.96 & 27.13 & 1.67 & 30.3 & 6775 \\
\hline Peru & 78.2 & 78.78 & 41.78 & 1.98 & 1211 \\
\hline Venezuela & 84.5 & 77.92 & 30.92 & 0.92 & 1200 \\
\hline Uruguay & 67.3 & 34.8 & 13.2 & 13.9 & 1000 \\
\hline Moldova & 63.72 & 75.2 & 10.77 & 8.94 & 984 \\
\hline Georgia & 44.43 & 73.81 & 9.53 & 6.56 & 2593 \\
\hline
\end{tabular}




\begin{tabular}{lccccc}
\hline Armenia & 23.8 & 72.75 & 7.3 & 13.2 & 2000 \\
Azerbaijan & 59.59 & 67.73 & 5.64 & 2.15 & 2002 \\
Dominican & 82.73 & 71.94 & 43.41 & 7.19 & 417 \\
Republ & & & & & \\
Bangladesh & 93.05 & 90.03 & 63.08 & 1.38 & 1525 \\
Colombia & 90.95 & 80.2 & 45.68 & 0.45 & 6025 \\
Serbia & 53.98 & 63.05 & 5.78 & 27.34 & 1280 \\
Montenegro & 37.08 & 52.08 & 7.08 & 30.42 & 240 \\
Macedonia & 58.09 & 71.16 & 10.95 & 14.47 & 995 \\
Croatia & 73.75 & 72.16 & 22.32 & 18.14 & 1196 \\
Bosnia & 64.83 & 77.75 & 31 & 13.92 & 1200 \\
& & & & & \\
All countries & 53.62 & 59.25 & 23.75 & 14.77 & 149653 \\
\hline
\end{tabular}


Panel B: Distribution of population by religious denomination and country (percentages)

\begin{tabular}{|c|c|c|c|c|c|c|c|c|}
\hline Country & Catholic & Protestant & Jewish & Muslim & Hindu & Buddhist & Other & No religious \\
\hline & & & & & & & Affiliations & Affiliations \\
\hline France & 63.18 & 1.68 & 0.32 & 0.45 & 0.05 & 0.68 & 16.09 & 17.55 \\
\hline Britain & 10.52 & 57.6 & 0.37 & 0.33 & 0.3 & 0.07 & 2.62 & 28.19 \\
\hline West Ger & 41.16 & 44.66 & 0.07 & 0.16 & 0.02 & 0.02 & 0.75 & 13.16 \\
\hline Italy & 86.89 & 0.12 & 0.03 & 0 & 0 & 0.06 & 0.77 & 12.13 \\
\hline Netherlands & 31.01 & 22.12 & 0 & 0.23 & 0.23 & 0.09 & 3.04 & 43.29 \\
\hline Denmark & 1.08 & 94.26 & 0.05 & 0.19 & 0.71 & 0.05 & 0.47 & 3.20 \\
\hline Belgium & 70.57 & 1.07 & 0.26 & 0.39 & 0 & 0.03 & 1.1 & 26.58 \\
\hline Spain & 84.7 & 0.53 & 0.03 & 0.06 & 0.01 & 0.04 & 0.6 & 14.03 \\
\hline Ireland & 94.77 & 2.86 & 0 & 0.05 & 0 & 0 & 0.5 & 1.82 \\
\hline N. Ireland & 27.08 & 65.12 & 0 & 0 & 0 & 0 & 2.82 & 4.98 \\
\hline U.S.A. & 28.57 & 46.87 & 1.77 & 0.29 & 0.2 & 0.38 & 9.41 & 12.52 \\
\hline Japan & 0.73 & 1.12 & 0.04 & 0 & 0.11 & 43.83 & 6.31 & 47.86 \\
\hline Mexico & 77.82 & 7.21 & 0.14 & 0.04 & 0.02 & 0.1 & 1.36 & 13.30 \\
\hline S. Africa & 11.59 & 58.78 & 1.46 & 2 & 1.88 & 0.1 & 14.17 & 10.01 \\
\hline Hungary & 70.86 & 26.41 & 0.36 & 0.31 & 0 & 0 & 1.44 & 0.62 \\
\hline Australia & 26.71 & 48.74 & 0.79 & 0.74 & 0.69 & 1.23 & 1.87 & 19.22 \\
\hline Norway & 0.76 & 92.65 & 0.03 & 0.38 & 0.03 & 0.09 & 2.92 & 3.15 \\
\hline Sweden & 3.21 & 87.6 & 0.14 & 0.17 & 0.03 & 0.03 & 8.81 & 0 \\
\hline Iceland & 0.44 & 98.07 & 0 & 0 & 0 & 0 & 1.5 & 0 \\
\hline Argentina & 78.17 & 1.49 & 1.69 & 0.1 & 0.1 & 0.13 & 4.25 & 14.06 \\
\hline Finland & 13.23 & 71.71 & 3.74 & 2.52 & 0 & 0 & 1.18 & 7.61 \\
\hline Poland & 94.82 & 1.84 & 0 & 0 & 0.05 & 0.05 & 1.45 & 1.79 \\
\hline Switzerland & 51.67 & 40.64 & 0.16 & 0.16 & 0.04 & 0.04 & 2.49 & 4.79 \\
\hline Puerto Rico & 56.91 & 7.86 & 0 & 0 & 8.29 & 0.35 & 7.86 & 18.74 \\
\hline Brazil & 70.32 & 6.73 & 0.03 & 0.07 & 0 & 0.14 & 10.84 & 11.87 \\
\hline Chile & 77.84 & 7.93 & 0.23 & 0 & 0.18 & 0.05 & 8.29 & 5.50 \\
\hline Belarus & 9.72 & 0.26 & 0.04 & 0.09 & 0.04 & 0 & 59.19 & 30.66 \\
\hline India & 2.1 & 1.28 & 0.04 & 8.47 & 83.72 & 0.66 & 1.61 & 2.10 \\
\hline East Ger & 11.96 & 18.21 & 0.09 & 0 & 0 & 0 & 0.43 & 69.31 \\
\hline Slovenia & 70.19 & 0.88 & 0 & 1.28 & 0 & 0 & 1.92 & 25.74 \\
\hline Bulgaria & 0.67 & 0.91 & 0.05 & 9.23 & 0.14 & 0 & 39.01 & 50.00 \\
\hline Romania & 2.27 & 3.45 & 0 & 0.18 & 0 & 0 & 88.21 & 5.89 \\
\hline Portugal & 77.13 & 0.34 & 0.08 & 0 & 0 & 0 & 1.01 & 21.43 \\
\hline Austria & 76.23 & 6.44 & 0.21 & 0 & 0 & 0 & 0.62 & 16.51 \\
\hline Turkey & 0.4 & 0.12 & 0.2 & 95.57 & 0 & 0 & 2.37 & 1.35 \\
\hline Lithuania & 83.28 & 1.6 & 0.25 & 0.06 & 0.06 & 0.12 & 6.48 & 8.14 \\
\hline Latvia & 23.75 & 21.76 & 0.4 & 0.33 & 0 & 0.07 & 23.95 & 29.74 \\
\hline Estonia & 0.61 & 15.38 & 0 & 0.35 & 0 & 0.44 & 19.67 & 63.55 \\
\hline Ukraine & 6.17 & 0.33 & 0.11 & 0.22 & 0.07 & 0.07 & 59.52 & 33.49 \\
\hline Russia & 5.11 & 1.07 & 0.07 & 1.62 & 0.01 & 0.79 & 25.9 & 65.42 \\
\hline Peru & 82.84 & 6.22 & 0 & 0.66 & 1.66 & 0.17 & 1.41 & 7.05 \\
\hline Venezuela & 84.54 & 6.4 & 0 & 0 & 0.09 & 0.09 & 1.2 & 7.69 \\
\hline Uruguay & 43.06 & 1.22 & 0.1 & 0 & 0 & 0.1 & 8.78 & 46.73 \\
\hline Moldova & 0.41 & 0.2 & 0 & 0.1 & 0 & 0 & 84.13 & 15.16 \\
\hline Georgia & 1.48 & 0.08 & 1.32 & 3.96 & 0 & 0.19 & 86.83 & 6.14 \\
\hline Armenia & 4.26 & 0.66 & 0.33 & 0 & 0 & 0 & 86.56 & 8.20 \\
\hline
\end{tabular}




\begin{tabular}{lcccccccc}
\hline Azerbaijan & 0.1 & 0.25 & 0.15 & 91.55 & 0 & 0 & 1.91 & 6.03 \\
$\begin{array}{l}\text { Dominican } \\
\text { Republic }\end{array}$ & 59.47 & 1.7 & 0 & 0 & 1.7 & 0 & 13.35 & 23.79 \\
Bangladesh & 0.99 & 0 & 0 & 85.86 & 12.82 & 0.2 & 0.13 & 0 \\
Colombia & 84.39 & 5.34 & 0.03 & 0 & 0 & 0 & 0 & 10.24 \\
Serbia & 6.33 & 0.87 & 0 & 5.78 & 0 & 0 & 68.88 & 18.13 \\
Montenegro & 8.47 & 0 & 0 & 21.61 & 0 & 0 & 64.41 & 5.51 \\
Macedonia & 0.71 & 0.1 & 0.31 & 24.31 & 0 & 0 & 46.69 & 27.87 \\
Croatia & 84.31 & 0.34 & 0.42 & 1.19 & 0.08 & 0 & 1.19 & 12.47 \\
Bosnia & 14.49 & 2.35 & 0.42 & 27.3 & 0 & 0 & 26.13 & 29.31 \\
& & & & & & & & \\
Total & 40.87 & 19.7 & 0.36 & 5.29 & 3.07 & 1.01 & 11.61 & 17.19 \\
\hline
\end{tabular}

Panel C. Religiosity by religious denomination (percentages)

\begin{tabular}{|c|c|c|c|}
\hline Country & $\begin{array}{l}\text { Raised religiously } \\
\text { at home }\end{array}$ & $\begin{array}{l}\text { Goes to church } \\
\text { at least once a } \\
\text { year }\end{array}$ & $\begin{array}{l}\text { Goes to church } \\
\text { at least once a } \\
\text { week }\end{array}$ \\
\hline Catholic & 70.3 & 75.3 & 38.8 \\
\hline Protestant & 47.4 & 59.5 & 25.0 \\
\hline Jew & 44.6 & 57.0 & 16.4 \\
\hline Muslim & 67.9 & 67.8 & 34.5 \\
\hline Hindu & 83.8 & 84.7 & 44.4 \\
\hline Buddhist & 22.2 & 75.8 & 8.3 \\
\hline Others & 51.0 & 68.2 & 17.0 \\
\hline
\end{tabular}


Panel D. Summary statistics of economic and social attitudes

\begin{tabular}{llllll}
\hline Variable & Mean & Median & SD & $\begin{array}{l}\text { Interq. } \\
\text { Range }\end{array}$
\end{tabular} Min Max

\section{Attitudes towards others}

1. Trust people $(0,1)$

2. Intolerant towards other races $(0,1)$

3. Intolerant towards the immigrants $(0,1)$

4. Average intolerance

$\begin{array}{cccccc}0.29 & 0 & 0.45 & 1 & 0 & 1 \\ 0.12 & 0 & 0.33 & 0 & 0 & 1 \\ 0.14 & 0 & 0.35 & 0 & 0 & 1 \\ 0.39 & 0.4 & 0.27 & 0.4 & 0 & 1\end{array}$

Attitudes towards the government

5.Trust the government

6. Trust the police

7. Trust the armed forces

0.93

0.91

2.61

0.94

\section{Attitudes towards women}

8. When jobs are scarce, men should have more right to a job than women

9. Do you think that women should have children in order to be fulfilled

10. Being a housewife is just as fulfilling as working for pay

11. Both the husband and wife should contribute to household income

12. A university education is more important for a boy than for a girl

\section{Attitudes toward legal rules}

13. Trust the legal system

14. It is justified to claim government benefits you are not entitled to?

15. It is justified to avoid a fare on public transport?

16. It is justified to cheat on taxes?

17. It is justified to buy a stolen object?

18. It is justified to accept a bribe?

Attitudes toward the market

19. Inequality of income gives incentives to individuals versus income should be made more equal

20. Private ownership should be increased versus government ownership should be increased

21. Competition is good versus competition is harmful

\section{Attitudes toward thriftiness}

22. Do you thinks to be especially important that children be encouraged to learn at home "thrift, saving money and things"

\section{Attitudes toward market's fairness}

23. Individual responsibility versus government assistance

$\begin{array}{cccccc}1.85 & 1 & 0.91 & 2 & 1 & 3 \\ 0.53 & 1 & 0.5 & 1 & 0 & 1 \\ & & & & & \\ 2.81 & 3 & 0.87 & 1 & 1 & 4 \\ & & & & & \\ 1.76 & 2 & 0.71 & 1 & 1 & 4 \\ & & & & & \\ 2.03 & 2 & 0.89 & 1 & 1 & 4 \\ & & & & & \\ 2.52 & 3 & 0.88 & 1 & 1 & 4 \\ & & & & & \\ 2.27 & 1 & 2.25 & 2 & 1 & 10 \\ & & & & & \\ 2.53 & 1 & 2.42 & 2 & 1 & 10 \\ 2.6 & 1 & 2.47 & 3 & 1 & 10 \\ 1.76 & 1 & 1.73 & 0 & 1 & 10 \\ 1.73 & 1 & 1.7 & 0 & 1 & 10\end{array}$

$\begin{array}{llllll}5.91 & 6 & 2.97 & 4 & 1 & 10\end{array}$

$\begin{array}{llllll}6.17 & 6 & 2.82 & 4 & 1 & 10\end{array}$

$\begin{array}{llllll}7.45 & 8 & 2.51 & 4 & 1 & 10\end{array}$

$\begin{array}{llllll}0.32 & 0 & 0.47 & 1 & 0 & 1\end{array}$

$\begin{array}{llllll}5.18 & 5 & 3.06 & 6 & 1 & 10\end{array}$




\begin{tabular}{|c|c|c|c|c|c|c|}
\hline Variable & Mean & Median & SD & $\begin{array}{l}\text { Interq. } \\
\text { Range }\end{array}$ & Min & Max \\
\hline $\begin{array}{l}\text { 24. Hard work improves life versus success is } \\
\text { more a matter of luck and connections. } \\
\text { 25. Wealth can grow so there's enough for } \\
\text { everyone versus one can get rich only at }\end{array}$ & 6.54 & 7 & 2.91 & 5 & 1 & 10 \\
\hline expense of others & 6.48 & 7 & 2.77 & 4 & 1 & 10 \\
\hline $\begin{array}{l}\text { 26. In your opinion who lives in need is poor } \\
\text { because of laziness and lack of will power }\end{array}$ & 0.1 & 0 & 0.3 & 0 & 0 & 1 \\
\hline
\end{tabular}

Panel E: Demographic characteristics

\begin{tabular}{lcccccc}
\hline & Mean & Median & Standard Deviation & Minimum & Maximum & Observations \\
\hline Health & 2.7 & 3 & 0.94 & 0 & 4 & 144704 \\
Male & 0.46 & 0 & 0.5 & 0 & 1 & 149653 \\
Age & 43.13 & 39 & 18.81 & 17 & 95 & 137520 \\
Education & 18.06 & 18 & 4.52 & 6 & 35 & 127855 \\
Social class & 2.52 & 2 & 1.49 & 0 & 5 & 145518 \\
Income & 4.75 & 4 & 2.59 & 0 & 10 & 122058 \\
\hline
\end{tabular}




\section{Table 2. Religion and social and economic attitudes}

All the variables are defined in the legend of table 1 . The row "Raised religiously+ Currently religious" reports the sum of the coefficients for "Raised religiously"+ "Currently religious", followed by the p-values for the test that the sum of the coefficients is significantly different from zero (in brackets). The row "Raised religiously+ Currently religious + Actively religious" reports the sum of the three coefficients, followed by the $p$-values for the test that the sum of the coefficients is significantly different from zero (in brackets). All the other numbers in brackets are standard errors. All the regressions include a country fixed effect and survey-year dummies. Panel A: Attitudes toward others and the government

\begin{tabular}{|c|c|c|c|c|c|c|c|}
\hline & Trust people & $\begin{array}{l}\text { Intolerant } \\
\text { toward other } \\
\text { races }\end{array}$ & $\begin{array}{l}\text { Intolerant } \\
\text { toward } \\
\text { immigrants }\end{array}$ & $\begin{array}{c}\text { Average } \\
\text { intolerance }\end{array}$ & $\begin{array}{l}\text { Trust the } \\
\text { government }\end{array}$ & $\begin{array}{l}\text { Trust the } \\
\text { police }\end{array}$ & $\begin{array}{l}\text { Trust the } \\
\text { army }\end{array}$ \\
\hline \multirow[t]{2}{*}{ Health } & $0.0424 * * *$ & $-0.0052 * * *$ & $-0.0096 * * *$ & $-0.0039 * * *$ & $0.0545^{* * *}$ & $0.0388 * * *$ & $0.0290 * * *$ \\
\hline & $(0.0017)$ & $(0.0012)$ & $(0.0014)$ & (0.0009) & $(0.0047)$ & $(0.0033)$ & $(0.0033)$ \\
\hline \multirow[t]{2}{*}{ Male } & 0.0027 & $0.0151 * * *$ & $0.0146^{* * *}$ & $0.0047 * * *$ & $0.0276^{* * *}$ & -0.0046 & $0.0532 * * *$ \\
\hline & $(0.0029)$ & $(0.0021)$ & $(0.0023)$ & $(0.0016)$ & $(0.0076)$ & $(0.0055)$ & $(0.0056)$ \\
\hline \multirow[t]{2}{*}{ Age } & $0.0011 * * *$ & $0.0009 * * *$ & $0.0006^{* * *}$ & $0.0016 * * *$ & $0.0048 * * *$ & $0.0048 * * *$ & $0.0069 * * *$ \\
\hline & $(0.0001)$ & $(0.0001)$ & $(0.0001)$ & $(0.0001)$ & $(0.0003)$ & $(0.0002)$ & $(0.0002)$ \\
\hline \multirow[t]{2}{*}{ Education } & $0.0057 * * *$ & $-0.0031 * * *$ & $-0.0030 * * *$ & $-0.0017 * * *$ & $-0.0072 * * *$ & $-0.0094 * * *$ & $-0.0110 * * *$ \\
\hline & $(0.0004)$ & $(0.0003)$ & $(0.0003)$ & $(0.0002)$ & $(0.0009)$ & $(0.0007)$ & $(0.0007)$ \\
\hline \multirow[t]{2}{*}{ Social class } & $0.0129 * * *$ & $0.0020^{*}$ & -0.0007 & -0.0011 & $0.0122 * * *$ & $0.0068 * *$ & -0.0036 \\
\hline & $(0.0015)$ & $(0.0011)$ & $(0.0012)$ & $(0.0008)$ & $(0.0042)$ & $(0.0028)$ & $(0.0028)$ \\
\hline \multirow[t]{2}{*}{ Income } & $0.0084 * * *$ & $-0.0040 * * *$ & $-0.0049 * * *$ & $-0.0016^{* * *}$ & $-0.0087 * * *$ & $-0.0086 * * *$ & $-0.0068 * * *$ \\
\hline & $(0.0007)$ & $(0.0005)$ & $(0.0005)$ & $(0.0004)$ & (0.0019) & $(0.0013)$ & $(0.0013)$ \\
\hline \multirow[t]{2}{*}{ Atheist } & $0.0313 * * *$ & -0.0010 & $0.0123 * * *$ & $-0.0053 * *$ & -0.0128 & $-0.0622 * * *$ & $-0.1358 * * *$ \\
\hline & $(0.0044)$ & $(0.0032)$ & $(0.0034)$ & $(0.0023)$ & $(0.0117)$ & $(0.0083)$ & $(0.0085)$ \\
\hline \multirow{2}{*}{$\begin{array}{l}\text { Raised } \\
\text { religiously }\end{array}$} & $0.0075^{*}$ & $0.0120 * * *$ & $0.0107 * * *$ & $0.0068 * * *$ & $0.0556^{* * *}$ & $0.0233 * * *$ & 0.0086 \\
\hline & $(0.0039)$ & $(0.0028)$ & $(0.0030)$ & $(0.0021)$ & $(0.0096)$ & $(0.0074)$ & $(0.0076)$ \\
\hline \multirow{2}{*}{$\begin{array}{l}\text { Currently } \\
\text { religious }\end{array}$} & $0.0179 * * *$ & $0.0077 * * *$ & $0.0092 * * *$ & $0.0166^{* * *}$ & $0.0939 * * *$ & $0.1032 * * *$ & $0.1277 * * *$ \\
\hline & $(0.0035)$ & $(0.0025)$ & $(0.0028)$ & $(0.0019)$ & $(0.0094)$ & $(0.0067)$ & $(0.0068)$ \\
\hline \multirow{2}{*}{$\begin{array}{l}\text { Actively } \\
\text { religious }\end{array}$} & $0.0314 * * *$ & $0.0055^{*}$ & 0.0020 & $0.0056^{* *}$ & $0.0448 * * *$ & $0.0964 * * *$ & $0.0860 * * *$ \\
\hline & $(0.0040)$ & $(0.0029)$ & $(0.0032)$ & $(0.0022)$ & $(0.0110)$ & $(0.0077)$ & $(0.0078)$ \\
\hline Number of obs & 95901 & 95739 & 91788 & 90340 & 52252 & 93803 & 94244 \\
\hline Adj. R squared & 0.094 & 0.070 & 0.066 & 0.279 & 0.127 & 0.171 & 0.199 \\
\hline Raised & $0.0254^{* * *}$ & $0.0197^{* * *}$ & $0.0199^{* * *}$ & $0.0234^{* * *}$ & $0.1495^{* * *}$ & $0.1265^{* * *}$ & $0.1363^{* * *}$ \\
\hline $\begin{array}{l}\text { religiously+ } \\
\text { Currently }\end{array}$ & $(0.0000)$ & $(0.0000)$ & $(0.0000)$ & $(0.0000)$ & $(0.0000)$ & $(0.0000)$ & $(0.0000)$ \\
\hline $\begin{array}{l}\text { religious } \\
\text { Raised } \\
\text { rolioioucl }\end{array}$ & $0.0568^{* * *}$ & $0.0252^{* * *}$ & $0.0219^{* * *}$ & $0.029^{* * *}$ & $0.1943^{* * *}$ & $0.2229^{* * *}$ & $0.2223^{* * *}$ \\
\hline
\end{tabular}




\begin{tabular}{|c|c|c|c|c|c|}
\hline \multirow[t]{3}{*}{$\begin{array}{l}\text { religiously } \\
\text { +currently } \\
\text { religious } \\
\text { +actively } \\
\text { religious } \\
\end{array}$} & $(0.0000)$ & $.0000)$ & $(0.0000)$ & $(0.0000)$ & $(0.0000)$ \\
\hline & \multicolumn{4}{|c|}{ Panel B: Attitudes toward women } & \\
\hline & $\begin{array}{c}\text { When jobs are } \\
\text { scarce, men should } \\
\text { have more right to } \\
\text { a job than women }\end{array}$ & $\begin{array}{l}\text { Do you think that } \\
\text { women should } \\
\text { have children in } \\
\text { order to be } \\
\text { fulfilled }\end{array}$ & $\begin{array}{c}\text { Being a } \\
\text { housewife is just } \\
\text { as fulfilling as } \\
\text { working for pay }\end{array}$ & $\begin{array}{c}\text { Both the } \\
\text { husband and } \\
\text { wife should } \\
\text { contribute to } \\
\text { household } \\
\text { income }\end{array}$ & $\begin{array}{c}\text { A university } \\
\text { education is more } \\
\text { important for a boy } \\
\text { than for a girl }\end{array}$ \\
\hline \multirow[t]{2}{*}{ Health } & $-0.0281 * * *$ & $-0.0067 * * *$ & $0.0120^{* * *}$ & -0.0045 & $-0.0235^{* * *}$ \\
\hline & $(0.0038)$ & $(0.0017)$ & $(0.0038)$ & $(0.0042)$ & $(0.0053)$ \\
\hline \multirow[t]{2}{*}{ Male } & $0.2126^{* * *}$ & $0.0164 * * *$ & $0.1266^{* * *}$ & $0.1380^{* * *}$ & $0.1880 * * *$ \\
\hline & $(0.0063)$ & $(0.0029)$ & $(0.0062)$ & $(0.0069)$ & $(0.0086)$ \\
\hline \multirow[t]{2}{*}{ Age } & $0.0046^{* * *}$ & $0.0026^{* * *}$ & $0.0037 * * *$ & $-0.0004 *$ & $0.0037 * * *$ \\
\hline & $(0.0002)$ & $(0.0001)$ & $(0.0002)$ & $(0.0002)$ & $(0.0003)$ \\
\hline \multirow[t]{2}{*}{ Education } & $-0.0197 * * *$ & $-0.0062 * * *$ & $-0.0122 * * *$ & $-0.0051^{* * *}$ & $-0.0102 * * *$ \\
\hline & $(0.0008)$ & $(0.0004)$ & $(0.0007)$ & $(0.0007)$ & $(0.0008)$ \\
\hline \multirow[t]{2}{*}{ Social class } & 0.0044 & 0.0011 & 0.0038 & -0.0057 & -0.0050 \\
\hline & $(0.0035)$ & $(0.0015)$ & $(0.0034)$ & $(0.0043)$ & $(0.0054)$ \\
\hline \multirow[t]{2}{*}{ Income } & $-0.0284 * * *$ & $-0.0045 * * *$ & $-0.0228 * * *$ & $0.0034 * *$ & $-0.0197 * * *$ \\
\hline & $(0.0015)$ & $(0.0007)$ & $(0.0015)$ & $(0.0017)$ & $(0.0021)$ \\
\hline \multirow[t]{2}{*}{ Atheist } & $-0.1114 * * *$ & $-0.0508 * * *$ & $-0.0969 * * *$ & -0.0131 & $-0.0373 * * *$ \\
\hline & $(0.0095)$ & $(0.0044)$ & $(0.0095)$ & $(0.0112)$ & $(0.0140)$ \\
\hline \multirow{2}{*}{$\begin{array}{l}\text { Raised } \\
\text { religiously }\end{array}$} & $0.0414 * * *$ & $0.0195 * * *$ & $0.0488 * * *$ & 0.0004 & 0.0165 \\
\hline & $(0.0080)$ & $(0.0039)$ & $(0.0079)$ & $(0.0085)$ & $(0.0107)$ \\
\hline \multirow{2}{*}{$\begin{array}{l}\text { Currently } \\
\text { religious }\end{array}$} & 0.0117 & $0.0317 * * *$ & $0.0526^{* * *}$ & $0.0206^{* *}$ & $0.0196^{*}$ \\
\hline & $(0.0077)$ & $(0.0035)$ & $(0.0076)$ & $(0.0085)$ & $(0.0106)$ \\
\hline \multirow{2}{*}{$\begin{array}{l}\text { Actively } \\
\text { religious }\end{array}$} & $0.0802 * * *$ & $0.0302 * * *$ & $0.1236^{* * *}$ & $0.0592 * * *$ & $0.0517 * * *$ \\
\hline & $(0.0088)$ & $(0.0040)$ & $(0.0087)$ & $(0.0095)$ & $(0.0119)$ \\
\hline Number of obs & 77347 & 94401 & 73467 & 40788 & 40025 \\
\hline Adj. R squared & 0.141 & 0.257 & 0.098 & 0.083 & 0.124 \\
\hline \multirow{2}{*}{$\begin{array}{l}\text { Raised } \\
\text { religiously+ } \\
\text { Currently } \\
\text { religious }\end{array}$} & $0.0531^{* * *}$ & $0.0512^{* * *}$ & $0.1014^{* * *}$ & $0.021^{*}$ & $0.0361^{* * *}$ \\
\hline & $(0.0000)$ & $(0.0000)$ & $(0.0000)$ & $(0.0601)$ & $(0.0097)$ \\
\hline \multirow{2}{*}{$\begin{array}{l}\text { Raised } \\
\text { religiously } \\
\text { +currently } \\
\text { religious } \\
\text { +actively } \\
\text { religious }\end{array}$} & $0.1333^{* * *}$ & $0.0814^{* * *}$ & $0.225^{* * *}$ & $0.0802^{* * *}$ & $0.0878^{* * *}$ \\
\hline & $(0.0000)$ & $(0.0000)$ & $(0.0000)$ & $(0.0000)$ & $(0.0000)$ \\
\hline
\end{tabular}




\section{Panel C: Attitudes towards legal rules}

\begin{tabular}{|c|c|c|c|c|c|c|}
\hline & $\begin{array}{l}\text { Trust the legal } \\
\text { system }\end{array}$ & $\begin{array}{l}\text { Is it justified } \\
\text { to claim } \\
\text { government } \\
\text { benefits you } \\
\text { are not entitled } \\
\text { to? }\end{array}$ & $\begin{array}{l}\text { Is it justified to } \\
\text { avoid a fare on } \\
\text { public } \\
\text { transport? }\end{array}$ & $\begin{array}{l}\text { Is it justified } \\
\text { to cheat on } \\
\text { taxes? }\end{array}$ & $\begin{array}{l}\text { Is it justified } \\
\text { to buy a } \\
\text { stolen } \\
\text { object? }\end{array}$ & $\begin{array}{c}\text { Is it justified } \\
\text { to accept a } \\
\text { bribe? }\end{array}$ \\
\hline Health & $\begin{array}{c}0.0428 * * * \\
(0.0033)\end{array}$ & $\begin{array}{c}-0.0634 * * * \\
(0.0087)\end{array}$ & $\begin{array}{c}-0.0596 * * * \\
(0.0092)\end{array}$ & $\begin{array}{c}-0.0479 * * * \\
(0.0096)\end{array}$ & $\begin{array}{c}-0.0294 * * * \\
(0.0066)\end{array}$ & $\begin{array}{c}-0.0324 * * * \\
(0.0065)\end{array}$ \\
\hline Male & $\begin{array}{l}-0.0059 \\
(0.0056)\end{array}$ & $\begin{array}{c}0.1006 * * * \\
(0.0147)\end{array}$ & $\begin{array}{c}0.1132 * * * \\
(0.0155)\end{array}$ & $\begin{array}{c}0.3027 * * * \\
(0.0161)\end{array}$ & $\begin{array}{c}0.1896^{* * *} \\
(0.0112)\end{array}$ & $\begin{array}{c}0.1518 * * * \\
(0.0110)\end{array}$ \\
\hline Age & $\begin{array}{c}0.0033^{* * *} \\
(0.0002)\end{array}$ & $\begin{array}{c}-0.0167^{* * *} \\
(0.0005)\end{array}$ & $\begin{array}{c}-0.0229 * * * \\
(0.0005)\end{array}$ & $\begin{array}{c}-0.0196 * * * \\
(0.0005)\end{array}$ & $\begin{array}{c}-0.0170^{* * *} \\
(0.0004)\end{array}$ & $\begin{array}{c}-0.0130 * * * \\
(0.0004)\end{array}$ \\
\hline Education & $\begin{array}{c}-0.0035^{* * *} \\
(0.0007)\end{array}$ & $\begin{array}{c}-0.0074 * * * \\
(0.0019)\end{array}$ & $\begin{array}{c}0.0074 * * * \\
(0.0020)\end{array}$ & $\begin{array}{c}0.0005 \\
(0.0020)\end{array}$ & $\begin{array}{c}-0.0062^{* * *} \\
(0.0014)\end{array}$ & $\begin{array}{c}-0.0048 * * * \\
(0.0014)\end{array}$ \\
\hline Social class & $\begin{array}{c}0.0005 \\
(0.0028)\end{array}$ & $\begin{array}{c}-0.0674 * * * \\
(0.0074)\end{array}$ & $\begin{array}{c}-0.0948 * * * \\
(0.0078)\end{array}$ & $\begin{array}{c}-0.0508^{* * *} \\
(0.0081)\end{array}$ & $\begin{array}{l}-0.0049 \\
(0.0056)\end{array}$ & $\begin{array}{c}-0.0079 \\
(0.0055)\end{array}$ \\
\hline Income & $\begin{array}{c}-0.0034 * * * \\
(0.0013)\end{array}$ & $\begin{array}{c}-0.0105^{* * *} \\
(0.0034)\end{array}$ & $\begin{array}{c}-0.0096^{* * *} \\
(0.0036)\end{array}$ & $\begin{array}{c}0.0352 * * * \\
(0.0037)\end{array}$ & $\begin{array}{l}-0.0038 \\
(0.0026)\end{array}$ & $\begin{array}{c}0.0073^{* * *} \\
(0.0025)\end{array}$ \\
\hline Atheist & $\begin{array}{c}-0.0291 * * * \\
(0.0084)\end{array}$ & $\begin{array}{c}0.1424 * * * \\
(0.0220)\end{array}$ & $\begin{array}{c}0.1997 * * * \\
(0.0232)\end{array}$ & $\begin{array}{c}0.2454 * * * \\
(0.0241)\end{array}$ & $\begin{array}{c}0.2042 * * * \\
(0.0167)\end{array}$ & $\begin{array}{l}0.0321 * \\
(0.0165)\end{array}$ \\
\hline Raised religiously & $\begin{array}{c}0.0470^{* * *} \\
(0.0075)\end{array}$ & $\begin{array}{c}-0.0473^{* *} \\
(0.0199)\end{array}$ & $\begin{array}{c}-0.1585^{* * *} \\
(0.0210)\end{array}$ & $\begin{array}{c}-0.1343^{* * *} \\
(0.0218)\end{array}$ & $\begin{array}{c}-0.0971^{* * *} \\
(0.0151)\end{array}$ & $\begin{array}{c}-0.0636^{* * *} \\
(0.0149)\end{array}$ \\
\hline Currently religious & $\begin{array}{c}0.0899 * * * \\
(0.0068)\end{array}$ & $\begin{array}{c}0.0257 \\
(0.0179)\end{array}$ & $\begin{array}{l}-0.0149 \\
(0.0188)\end{array}$ & $\begin{array}{c}-0.0483 * * \\
(0.0196)\end{array}$ & $\begin{array}{c}-0.0335^{* *} \\
(0.0136)\end{array}$ & $\begin{array}{c}-0.0094 \\
(0.0134)\end{array}$ \\
\hline Actively & $\begin{array}{c}0.0740 * * * \\
(0.0077)\end{array}$ & $\begin{array}{c}-0.0920 * * * \\
(0.0204)\end{array}$ & $\begin{array}{c}-0.1699 * * * \\
(0.0215)\end{array}$ & $\begin{array}{c}-0.2801 * * * \\
(0.0224)\end{array}$ & $\begin{array}{c}-0.1568^{* * *} \\
(0.0155)\end{array}$ & $\begin{array}{c}-0.0897 * * * \\
(0.0153)\end{array}$ \\
\hline Number of obs & 94259 & 91793 & 93034 & 92392 & 93161 & 92878 \\
\hline Adj. R squared & 0.092 & 0.090 & 0.120 & 0.094 & 0.070 & 0.067 \\
\hline $\begin{array}{l}\text { Raised religiously+ } \\
\text { Currently religious }\end{array}$ & $\begin{array}{l}0.1369^{* * *} \\
(0.0000)\end{array}$ & $\begin{array}{l}-0.0216 \\
(0.3876)\end{array}$ & $\begin{array}{l}-0.1734^{* * *} \\
(0.0000)\end{array}$ & $\begin{array}{l}-0.1826^{* * *} \\
(0.0000)\end{array}$ & $\begin{array}{l}-0.1306^{* * *} \\
(0.0000)\end{array}$ & $\begin{array}{l}-0.073^{* * *} \\
(0.0001)\end{array}$ \\
\hline $\begin{array}{c}\text { Raised religiously } \\
+ \text { currently } \\
\text { religious } \\
\text { +actively religious } \\
\end{array}$ & $\begin{array}{l}0.2109^{* * *} \\
(0.0000)\end{array}$ & $\begin{array}{l}-0.1136^{* * *} \\
(0.0000)\end{array}$ & $\begin{array}{l}-0.3433^{* * *} \\
(0.0000)\end{array}$ & $\begin{array}{l}-0.4627^{* * *} \\
(0.0000)\end{array}$ & $-0.2874^{* * *}$ & $\begin{array}{l}-0.1627^{* * *} \\
(0.0000)\end{array}$ \\
\hline
\end{tabular}


Panel D: Attitudes toward the market

\begin{tabular}{|c|c|c|c|}
\hline & $\begin{array}{l}\text { Inequality of } \\
\text { income vs. } \\
\text { incentives }\end{array}$ & $\begin{array}{c}\text { Private vs. } \\
\text { public ownership }\end{array}$ & $\begin{array}{l}\text { Competition is } \\
\text { good or harmful }\end{array}$ \\
\hline Health & $\begin{array}{c}0.0965 * * * \\
(0.0126)\end{array}$ & $\begin{array}{c}0.1247 * * * \\
(0.0121)\end{array}$ & $\begin{array}{c}0.1182 * * * \\
(0.0110)\end{array}$ \\
\hline Male & $\begin{array}{c}0.1923 * * * \\
(0.0207)\end{array}$ & $\begin{array}{c}0.4641 * * * \\
(0.0199)\end{array}$ & $\begin{array}{c}0.3098 * * * \\
(0.0181)\end{array}$ \\
\hline Age & $\begin{array}{c}-0.0015 * * \\
(0.0007)\end{array}$ & $\begin{array}{c}-0.0054 * * * \\
(0.0007)\end{array}$ & $\begin{array}{c}0.0025 * * * \\
(0.0006)\end{array}$ \\
\hline Education & $\begin{array}{c}0.0390 * * * \\
(0.0026)\end{array}$ & $\begin{array}{c}0.0114 * * * \\
(0.0025)\end{array}$ & $\begin{array}{c}0.0115 * * * \\
(0.0023)\end{array}$ \\
\hline Social class & $\begin{array}{c}0.2168 * * * \\
(0.0115)\end{array}$ & $\begin{array}{c}0.2003 * * * \\
(0.0111)\end{array}$ & $\begin{array}{c}0.1318 * * * \\
(0.0101)\end{array}$ \\
\hline Income & $\begin{array}{c}0.1174 * * * \\
(0.0049)\end{array}$ & $\begin{array}{c}0.0755 * * * \\
(0.0047)\end{array}$ & $\begin{array}{c}0.0467 * * * \\
(0.0043)\end{array}$ \\
\hline Atheist & $\begin{array}{c}-0.2102 * * * \\
(0.0310)\end{array}$ & $\begin{array}{c}-0.2258 * * * \\
(0.0298)\end{array}$ & $\begin{array}{c}-0.0924 * * * \\
(0.0271)\end{array}$ \\
\hline Raised religiously & $\begin{array}{c}-0.0843 * * * \\
(0.0262)\end{array}$ & $\begin{array}{c}-0.0653 * * * \\
(0.0251)\end{array}$ & $\begin{array}{l}-0.0081 \\
(0.0229)\end{array}$ \\
\hline Currently religious & $\begin{array}{l}-0.0215 \\
(0.0254)\end{array}$ & $\begin{array}{c}0.1326 * * * \\
(0.0245)\end{array}$ & $\begin{array}{c}0.0622 * * * \\
(0.0223)\end{array}$ \\
\hline Actively religious & $\begin{array}{l}0.0512 * \\
(0.0297)\end{array}$ & $\begin{array}{c}0.1179 * * * \\
(0.0287)\end{array}$ & $\begin{array}{l}-0.0054 \\
(0.0260)\end{array}$ \\
\hline Number of obs & 74126 & 71881 & 73311 \\
\hline Adj. R squared & 0.100 & 0.130 & 0.064 \\
\hline $\begin{array}{l}\text { Raised religiously+ } \\
\text { Currently religious }\end{array}$ & $\begin{array}{l}-0.1058^{* * *} \\
(0.0016)\end{array}$ & $\begin{array}{l}0.0673^{* *} \\
(0.0370)\end{array}$ & $\begin{array}{l}0.0541^{*} \\
(0.0661)\end{array}$ \\
\hline $\begin{array}{l}\text { Raised religiously } \\
+ \text { currently religious } \\
\text { +actively religious }\end{array}$ & -0.0546 & $0.1852^{* * *}$ & $(0.1410)$ \\
\hline
\end{tabular}


Panel E: Attitudes toward thriftiness and market's fairness

\begin{tabular}{|c|c|c|c|c|c|}
\hline & $\begin{array}{l}\text { Thrift to be } \\
\text { encouraged }\end{array}$ & $\begin{array}{l}\text { Individual vs. } \\
\text { government } \\
\text { responsibility }\end{array}$ & $\begin{array}{l}\text { Hard work } \\
\text { improves life }\end{array}$ & $\begin{array}{l}\text { Wealth can } \\
\text { grow for } \\
\text { everyone }\end{array}$ & Poor are lazy \\
\hline Health & $\begin{array}{c}-0.0110^{* * *} \\
(0.0018)\end{array}$ & $\begin{array}{c}0.1270^{* * *} \\
(0.0125)\end{array}$ & $\begin{array}{c}0.1336^{* * *} \\
(0.0126)\end{array}$ & $\begin{array}{c}0.0981 * * * \\
(0.0124)\end{array}$ & $\begin{array}{c}0.0071 * * * \\
(0.0011)\end{array}$ \\
\hline Male & $\begin{array}{c}0.0036 \\
(0.0030)\end{array}$ & $\begin{array}{c}0.2517 * * * \\
(0.0205)\end{array}$ & $\begin{array}{c}0.2625^{* * *} \\
(0.0208)\end{array}$ & $\begin{array}{c}-0.0889 * * * \\
(0.0204)\end{array}$ & $\begin{array}{c}0.0177 * * * \\
(0.0018)\end{array}$ \\
\hline Age & $\begin{array}{c}0.0024^{* * *} \\
(0.0001)\end{array}$ & $\begin{array}{c}0.0003 \\
(0.0007)\end{array}$ & $\begin{array}{c}0.0152 * * * \\
(0.0007)\end{array}$ & $\begin{array}{c}0.0087 * * * \\
(0.0007)\end{array}$ & $\begin{array}{l}-0.0000 \\
(0.0001)\end{array}$ \\
\hline Education & $\begin{array}{c}-0.0063 * * * \\
(0.0004)\end{array}$ & $\begin{array}{c}0.0092 * * * \\
(0.0025)\end{array}$ & $\begin{array}{c}-0.0061^{* *} \\
(0.0026)\end{array}$ & $\begin{array}{c}0.0168^{* * *} \\
(0.0026)\end{array}$ & $\begin{array}{c}-0.0023^{* * *} \\
(0.0002)\end{array}$ \\
\hline Social class & $\begin{array}{c}-0.0133 * * * \\
(0.0015)\end{array}$ & $\begin{array}{c}0.1612 * * * \\
(0.0114)\end{array}$ & $\begin{array}{c}0.0894 * * * \\
(0.0115)\end{array}$ & $\begin{array}{l}-0.0035 \\
(0.0113)\end{array}$ & $\begin{array}{c}0.0142 * * * \\
(0.0009)\end{array}$ \\
\hline Income & $\begin{array}{c}-0.0070 * * * \\
(0.0007)\end{array}$ & $\begin{array}{c}0.0731 * * * \\
(0.0049)\end{array}$ & $\begin{array}{c}0.0233 * * * \\
(0.0049)\end{array}$ & $\begin{array}{c}0.0324 * * * \\
(0.0048)\end{array}$ & $\begin{array}{c}0.0036^{* * * *} \\
(0.0004)\end{array}$ \\
\hline Atheist & $\begin{array}{c}-0.0193 * * * \\
(0.0044)\end{array}$ & $\begin{array}{l}-0.0530^{*} \\
(0.0312)\end{array}$ & $\begin{array}{c}-0.0926^{* * *} \\
(0.0311)\end{array}$ & $\begin{array}{c}-0.1397 * * * \\
(0.0305)\end{array}$ & $\begin{array}{c}0.0013 \\
(0.0027)\end{array}$ \\
\hline Raised religiously & $\begin{array}{c}0.0157 * * * \\
(0.0040)\end{array}$ & $\begin{array}{l}-0.0266 \\
(0.0261)\end{array}$ & $\begin{array}{c}0.1357 * * * \\
(0.0262)\end{array}$ & $\begin{array}{l}-0.0039 \\
(0.0257)\end{array}$ & $\begin{array}{l}0.0044^{*} \\
(0.0024)\end{array}$ \\
\hline Currently religious & $\begin{array}{l}0.0064^{*} \\
(0.0036)\end{array}$ & $\begin{array}{c}0.0897 * * * \\
(0.0253)\end{array}$ & $\begin{array}{c}0.1189 * * * \\
(0.0255)\end{array}$ & $\begin{array}{c}0.1205^{* * *} \\
(0.0250)\end{array}$ & $\begin{array}{c}0.0075^{* * *} * \\
(0.0022)\end{array}$ \\
\hline Actively religious & $\begin{array}{c}-0.0156^{* * *} \\
(0.0041)\end{array}$ & $\begin{array}{c}0.0876^{* * *} \\
(0.0291)\end{array}$ & $\begin{array}{c}0.1772 * * * \\
(0.0297)\end{array}$ & $\begin{array}{c}0.1927 * * * \\
(0.0292)\end{array}$ & $\begin{array}{c}0.0072 * * * \\
(0.0025)\end{array}$ \\
\hline Number of obs & 94920 & 77217 & 74349 & 72229 & 92343 \\
\hline Adj. R squared & 0.108 & 0.155 & 0.080 & 0.042 & 0.231 \\
\hline $\begin{array}{l}\text { Raised religiously+ } \\
\text { Currently religious }\end{array}$ & $\begin{array}{l}0.0221^{* * *} \\
(0.0000)\end{array}$ & $\begin{array}{l}0.0631^{*} \\
(0.0595)\end{array}$ & $\begin{array}{l}0.2546^{* * *} \\
(0.0000)\end{array}$ & $\begin{array}{l}0.1166^{* * *} \\
(0.0004)\end{array}$ & $\begin{array}{l}0.0119^{* * *} \\
(0.0001)\end{array}$ \\
\hline $\begin{array}{l}\text { Raised religiously } \\
+ \text { currently } \\
\text { religious } \\
+ \text { actively religious }\end{array}$ & $(0.2320)$ & $0.1507^{* * *}$ & $0.4318^{* * *}$ & $0.3093^{* * *}$ & $0.0191^{* * *}$ \\
\hline
\end{tabular}




\section{Table 3. The role of the dominant religion}

All the panels report coefficients from different OLS regressions. The dependent variable of each regression is indicated at the top of the column and is defined in the legend of Table 1. All regressions include (coefficients not reported) the same demographic controls as in Table 2 (health, male, age, education, social class, income), an indicator variable equal to 1 if a person answer no to the question "Do you believe in God?", a country fixed effect, and survey-year dummies. "Raised religiously" is an indicator variable equal to one if the respondent answered positively to the question "Were you brought up religiously at home?". "Currently religious" is an indicator variable that is equal to one if the respondent attend religious services (apart from weddings, funerals and christenings) at least once a year. "Actively religious" is an indicator variable that is equal to one if the respondent attend religious services (apart from weddings, funerals and christenings) at least once a week. "Raised religiously in dominant religion" is an indicator variable equal to one if "Raised religiously" is equal to one and the respondent belongs to the religious denomination most followed in his/her country. "Currently religious in dominant religion" is an indicator variable equal to one if "Currently religious" is equal to one and the respondent belongs to the religious denomination most followed in his/her country. "Actively religious in dominant religion" is an indicator variable equal to one if "Actively religious" is equal to one and the respondent belongs to the religious denomination most followed in his/her country. Standard errors are reported in brackets.

\section{Panel A: Attitudes towards others and the government}

\begin{tabular}{|c|c|c|c|c|c|c|c|}
\hline & Trust people & $\begin{array}{l}\text { Intolerant } \\
\text { toward other } \\
\text { races }\end{array}$ & $\begin{array}{l}\text { Intolerant } \\
\text { toward } \\
\text { immigrants }\end{array}$ & $\begin{array}{c}\text { Average } \\
\text { intolerance }\end{array}$ & $\begin{array}{c}\text { Trust the } \\
\text { government }\end{array}$ & $\begin{array}{l}\text { Trust the } \\
\text { police }\end{array}$ & $\begin{array}{l}\text { Trust the } \\
\text { armed } \\
\text { forces }\end{array}$ \\
\hline Raised religiously & $\begin{array}{c}0.0167 * * * \\
(0.0057)\end{array}$ & $\begin{array}{c}0.0007 \\
(0.0040)\end{array}$ & $\begin{array}{c}0.0002 \\
(0.0044)\end{array}$ & $\begin{array}{l}-0.0039 \\
(0.0030)\end{array}$ & $\begin{array}{c}0.0432 * * * \\
(0.0144)\end{array}$ & $\begin{array}{c}-0.0279 * * * \\
(0.0107)\end{array}$ & $\begin{array}{c}-0.0439 * * * \\
(0.0110)\end{array}$ \\
\hline Currently religious & $\begin{array}{c}0.0181 * * * \\
(0.0059)\end{array}$ & $\begin{array}{c}0.0051 \\
(0.0042)\end{array}$ & $\begin{array}{c}0.0024 \\
(0.0045)\end{array}$ & $\begin{array}{c}0.0123 * * * \\
(0.0031)\end{array}$ & $\begin{array}{c}0.0589 * * * \\
(0.0153)\end{array}$ & $\begin{array}{c}0.0711^{* * *} \\
(0.0112)\end{array}$ & $\begin{array}{c}0.0684 * * * \\
(0.0114)\end{array}$ \\
\hline Actively religious & $\begin{array}{c}0.0323 * * * \\
(0.0082)\end{array}$ & $\begin{array}{c}0.0072 \\
(0.0058)\end{array}$ & $\begin{array}{l}-0.0026 \\
(0.0063)\end{array}$ & $\begin{array}{l}-0.0052 \\
(0.0043)\end{array}$ & $\begin{array}{l}0.0387 * \\
(0.0217)\end{array}$ & $\begin{array}{c}0.0915^{* * *} \\
(0.0154)\end{array}$ & $\begin{array}{c}0.0530 * * * \\
(0.0157)\end{array}$ \\
\hline $\begin{array}{l}\text { Raised religiously } \\
\text { in dominant } \\
\text { religion }\end{array}$ & $\begin{array}{c}-0.0156^{* * *} \\
(0.0060)\end{array}$ & $\begin{array}{c}0.0148^{* * *} \\
(0.0043)\end{array}$ & $\begin{array}{c}0.0144 * * * \\
(0.0047)\end{array}$ & $\begin{array}{c}0.0169 * * * \\
(0.0032)\end{array}$ & $\begin{array}{c}0.0165 \\
(0.0162)\end{array}$ & $\begin{array}{c}0.0787 * * * \\
(0.0114)\end{array}$ & $\begin{array}{c}0.0809 * * * \\
(0.0116)\end{array}$ \\
\hline $\begin{array}{l}\text { Currently religious } \\
\text { in dominant } \\
\text { religion }\end{array}$ & $\begin{array}{c}0.0044 \\
(0.0066)\end{array}$ & $\begin{array}{c}0.0022 \\
(0.0047)\end{array}$ & $\begin{array}{c}0.0041 \\
(0.0051)\end{array}$ & $\begin{array}{c}0.0052 \\
(0.0035)\end{array}$ & $\begin{array}{l}0.0315^{*} \\
(0.0176)\end{array}$ & $\begin{array}{c}0.0331^{* * *} \\
(0.0125)\end{array}$ & $\begin{array}{c}0.0840 * * * \\
(0.0127)\end{array}$ \\
\hline $\begin{array}{l}\text { Actively religious } \\
\text { in dominant } \\
\text { religion }\end{array}$ & $\begin{array}{l}-0.0015 \\
(0.0092)\end{array}$ & $\begin{array}{l}-0.0017 \\
(0.0066)\end{array}$ & $\begin{array}{c}0.0064 \\
(0.0072)\end{array}$ & $\begin{array}{c}0.0137 * * * \\
(0.0050)\end{array}$ & $\begin{array}{c}0.0145 \\
(0.0247)\end{array}$ & $\begin{array}{c}0.0083 \\
(0.0174)\end{array}$ & $\begin{array}{l}0.0429 * * \\
(0.0178)\end{array}$ \\
\hline Number of obs. & 89677 & 89530 & 85614 & 84179 & 47667 & 87680 & 88124 \\
\hline$R$ squared & 0.095 & 0.073 & 0.070 & 0.272 & 0.132 & 0.171 & 0.197 \\
\hline
\end{tabular}


Panel B: Attitudes towards women

\begin{tabular}{lccccc}
\hline & $\begin{array}{c}\text { When jobs are } \\
\text { scarce, men } \\
\text { should have more } \\
\text { right to a job than } \\
\text { women }\end{array}$ & $\begin{array}{c}\text { Do you think that } \\
\text { women should } \\
\text { have children in } \\
\text { order to be } \\
\text { fulfilled }\end{array}$ & $\begin{array}{c}\text { Being a housewife } \\
\text { is just as fulfilling as } \\
\text { working for pay }\end{array}$ & $\begin{array}{c}\text { Both the husband } \\
\text { and wife should } \\
\text { contribute to } \\
\text { household income }\end{array}$ & $\begin{array}{c}\text { A university } \\
\text { education is more } \\
\text { important for a boy } \\
\text { than for a girl }\end{array}$ \\
\hline Raised religiously & 0.0019 & 0.0083 & $0.0296^{* *}$ & -0.0070 & 0.0231 \\
Currently religious & $(0.0118)$ & $(0.0057)$ & $(0.0117)$ & $(0.0131)$ & $(0.0163)$ \\
Actively religious & $0.0274^{* *}$ & $0.0287^{* * *}$ & $0.0373^{* * *}$ & 0.0013 & $0.0502^{* * *}$ \\
Raised religiously in & $0.1397^{* * *}$ & $0.0440^{* * *}$ & $0.1848^{* * *}$ & $0.1142^{* * *}$ & $(0.0178)$ \\
dominant religion & $(0.0182)$ & $(0.0082)$ & $(0.0180)$ & $(0.0199)$ & 0.0200 \\
Currently religious & $0.0643^{* * *}$ & $0.0206^{* * *}$ & $0.0312^{* *}$ & 0.0099 & $(0.0247)$ \\
in dominant religion & $(0.0130)$ & $(0.0060)$ & $(0.0129)$ & $(0.0144)$ & -0.0210 \\
Actively religious in & -0.0108 & 0.0042 & $0.0294^{* *}$ & 0.0218 & $-0.0179)$ \\
dominant religion & $(0.0148)$ & $(0.0066)$ & $(0.0147)$ & $(0.0159)$ & $(0.0198)$ \\
Number of obs. & $(0.021)^{* * *}$ & $-0.0198^{* *}$ & $-0.0797^{* * *}$ & $-0.0679^{* * *}$ & 0.0399 \\
$R$ squared & 72186 & $(0.0092)$ & $(0.0203)$ & $(0.0223)$ & $(0.0277)$ \\
\hline
\end{tabular}

Panel C: Attitudes towards legal rules

\begin{tabular}{lcccccc}
\hline & $\begin{array}{c}\text { Trust the legal } \\
\text { system? }\end{array}$ & $\begin{array}{c}\text { Is it justified to } \\
\text { claim } \\
\text { government } \\
\text { benefits you are } \\
\text { not entitled to? }\end{array}$ & $\begin{array}{c}\text { Is it justified to } \\
\text { pvoid a fare on } \\
\text { public transport? }\end{array}$ & $\begin{array}{c}\text { Is it justified to } \\
\text { cheat on taxes? }\end{array}$ & $\begin{array}{c}\text { Is it justified to } \\
\text { buy a stolen } \\
\text { object? }\end{array}$ & $\begin{array}{c}\text { Is it justified } \\
\text { to accept a } \\
\text { bribe? }\end{array}$ \\
\hline Raised religiously & 0.0134 & -0.0304 & $-0.1127^{* * *}$ & $-0.1127^{* * *}$ & $-0.0696^{* * *}$ & $-0.0745^{* * *}$ \\
Currently religious & $(0.0108)$ & $(0.0283)$ & $(0.0298)$ & $(0.0298)$ & $(0.0212)$ & $(0.0210)$ \\
Actively religious & $0.0531^{* * *}$ & $0.1079^{* * *}$ & $0.0877^{* * *}$ & $0.0877^{* * *}$ & $0.0463^{* *}$ & $0.0702^{* * *}$ \\
& $(0.0113)$ & $(0.0295)$ & $(0.0310)$ & $(0.0310)$ & $(0.0221)$ & $(0.0219)$ \\
Raised religiously & $0.0835^{* * *}$ & $-0.1143^{* * *}$ & $-0.3117^{* * *}$ & $-0.3117^{* * *}$ & $-0.2457^{* * *}$ & $-0.1580^{* * *}$ \\
in dominant & $(0.0156)$ & $(0.0405)$ & $(0.0428)$ & $(0.0428)$ & $(0.0305)$ & $(0.0301)$ \\
religion & $0.0469^{* * *}$ & -0.0231 & $-0.0710^{* *}$ & $-0.0710^{* *}$ & -0.0193 & 0.0316 \\
Currently religious & $(0.0115)$ & $(0.0301)$ & $(0.0317)$ & $(0.0317)$ & $(0.0226)$ & $(0.0223)$ \\
in dominant & $0.0367^{* * *}$ & $-0.1107^{* * *}$ & $-0.1428^{* * *}$ & $-0.1428^{* * *}$ & $-0.1140^{* * *}$ & $-0.1095^{* * *}$ \\
religion & $(0.0126)$ & $(0.0330)$ & $(0.0347)$ & $(0.0347)$ & $(0.0247)$ & $(0.0245)$ \\
Actively religious & -0.0056 & 0.0323 & $0.1921^{* * *}$ & $0.1921^{* * *}$ & $0.1223^{* * *}$ & $0.0849^{* *}$ \\
in dominant & $(0.0177)$ & $(0.0460)$ & $(0.0486)$ & $(0.0486)$ & $(0.0346)$ & $(0.0342)$ \\
religion & 88157 & 86095 & 87224 & 87224 & 87356 & 87082 \\
Number of obs. & 0.091 & 0.094 & 0.124 & 0.124 & 0.070 & 0.067 \\
$R$ squared & & &
\end{tabular}


Panel D: Attitudes towards the market

\begin{tabular}{lccc}
\hline & $\begin{array}{c}\text { Inequality of income vs. } \\
\text { incentives }\end{array}$ & $\begin{array}{c}\text { Private vs. public } \\
\text { ownership }\end{array}$ & $\begin{array}{c}\text { Competition is good or } \\
\text { harmful }\end{array}$ \\
\hline Raised religiously & $-0.0762^{* *}$ & $-0.1099^{* * *}$ & $-0.0894^{* * *}$ \\
Currently religious & $(0.0386)$ & $(0.0369)$ & $(0.0337)$ \\
Actively religious & 0.0345 & $0.1464^{* * *}$ & $0.1195^{* * *}$ \\
& $(0.0425)$ & $(0.0406)$ & $(0.0371)$ \\
Raised religiously in dominant & 0.0595 & $0.1124^{* *}$ & -0.0474 \\
religion & $(0.0598)$ & $(0.0571)$ & $(0.0523)$ \\
Currently religious in dominant & 0.0189 & $0.0693^{*}$ & $0.1282^{* * *}$ \\
religion & $(0.0428)$ & $(0.0410)$ & $(0.0374)$ \\
Actively religious in dominant & -0.0665 & -0.0225 & $-0.0787^{*}$ \\
religion & $(0.0487)$ & $(0.0465)$ & $(0.0425)$ \\
& -0.0279 & 0.0098 & 0.0498 \\
Number of obs. & $(0.0679)$ & $(0.0650)$ & $(0.0594)$ \\
R squared & & & 68177 \\
\hline
\end{tabular}

Panel E: Attitudes toward thriftiness and market's fairness

\begin{tabular}{lccccc}
\hline & $\begin{array}{c}\text { Thrift to be } \\
\text { encouraged }\end{array}$ & $\begin{array}{c}\text { Individual vs. } \\
\text { government } \\
\text { responsibility }\end{array}$ & $\begin{array}{c}\text { Hard work } \\
\text { improves life }\end{array}$ & $\begin{array}{c}\text { Wealth can grow } \\
\text { for everyone }\end{array}$ & Poor are lazy \\
\hline Raised religiously & $0.0120^{* *}$ & $-0.1770^{* * *}$ & 0.0516 & 0.0263 & 0.0003 \\
Currently religious & $(0.0057)$ & $(0.0385)$ & $(0.0385)$ & $(0.0378)$ & $(0.0035)$ \\
Actively religious & -0.0009 & $0.1401^{* * *}$ & $0.1405^{* * *}$ & $0.1171^{* * *}$ & $0.0130^{* * *}$ \\
& $(0.0060)$ & $(0.0425)$ & $(0.0423)$ & $(0.0417)$ & $(0.0036)$ \\
Raised religiously in & -0.0112 & $0.1165^{*}$ & $0.2629^{* * *}$ & $0.1097^{*}$ & $0.0096^{*}$ \\
dominant religion & $(0.0082)$ & $(0.0596)$ & $(0.0596)$ & $(0.0585)$ & $(0.0050)$ \\
Currently religious in & 0.0051 & $0.2081^{* * *}$ & $0.1381^{* * *}$ & -0.0562 & $0.0077^{* *}$ \\
dominant religion & $(0.0061)$ & $(0.0425)$ & $(0.0427)$ & $(0.0420)$ & $(0.0037)$ \\
Actively religious in & $0.0115 *$ & $-0.0943^{*}$ & -0.0485 & -0.0012 & $-0.0082^{* *}$ \\
dominant religion & $(0.0067)$ & $(0.0485)$ & $(0.0484)$ & $(0.0478)$ & $(0.0041)$ \\
& -0.0055 & -0.0484 & $-0.1243 *$ & $0.1165 *$ & -0.0034 \\
Number of obs. & $(0.0093)$ & $(0.0673)$ & $(0.0677)$ & $(0.0665)$ & $(0.0057)$ \\
$R$ squared & & & & 67327 & 86305 \\
\hline
\end{tabular}




\section{Table 4: The role of religious denominations}

Each panel reports the coefficients of an OLS regression, whose dependent variable is indicated at the top of the panel. Dependent variables are defined in the legend of Table 1. Regressions include the same demographic controls as in Table 2 (health, male, age, education, social class, income; coefficients not reported), an dummy variable equal to 1 if a person does not believe in God, country fixed effects, and survey-year dummies. Included are also the following indicators of religious intensity: "Raised religiously":=1 if the respondent answered "yes" to the question "Were you brought up religiously at home?"; "Currently religious": $=1$ if the respondent attends religious services (apart from weddings, funerals and christenings) at least once a year; "Actively religious": $=1$ if the respondent attend religious services (apart from weddings, funerals and christenings) at least once a week. Entries in columns 2 to 4 are the coefficients of the variables obtained interacting the corresponding variable in the first column with that in the first row. Entries in the last two columns are the sum of the coefficients of the specified variables. They should be interpreted as the cumulative effect of the different degree of religiosity, relatively to individuals who declare they have no religious affiliation. In the first three columns, standard errors are reported in brackets; in the last two columns $p$-values for the $F$-test that the coefficient is equal to zero are reported in brackets. $* * *$ indicate the coefficient is different from zero at the $1 \%$ level, $* *$ at the $5 \%$ level , and $*$ at the $10 \%$ level.

A. General trust (N. of observations: 91,$\left.656 ; R^{2}: 0.094\right)$

\begin{tabular}{lcccccc}
\hline & $\begin{array}{c}\text { Raised } \\
\text { religiously }\end{array}$ & $\begin{array}{c}\text { Currently } \\
\text { religious }\end{array}$ & $\begin{array}{c}\text { Actively } \\
\text { religious }\end{array}$ & $\begin{array}{c}\text { Raised religiously } \\
\text { +Currently } \\
\text { Religious }\end{array}$ & $\begin{array}{c}\text { Raised religiously } \\
\text { +Currently } \\
\text { Religious }\end{array}$ & $\begin{array}{c}\text { Total weighted } \\
\text { impact of religion } \\
\text { Actively Religious }\end{array}$ \\
\hline Catholic & $-0.0132^{* *}$ & $0.0089^{*}$ & $0.0431^{* * *}$ & -0.0043 & $0.0388^{* * *}$ & $0.0141^{* * *}$ \\
Protestant & $(0.0053)$ & $(0.0053)$ & $(0.0054)$ & $(0.4396)$ & $(0.0000)$ & $(0.0001)$ \\
Jew & -0.0005 & $0.0307^{* * *}$ & $0.0395^{* * *}$ & $0.0302^{* * *}$ & $0.0697^{* * *}$ & $0.0279^{* * *}$ \\
& $(0.0076)$ & $(0.0068)$ & $(0.0102)$ & $(0.0002)$ & $(0.0000)$ & $(0.0000)$ \\
Muslim & 0.0508 & -0.0051 & -0.0069 & 0.0457 & 0.0388 & 0.0186 \\
Hindu & $(0.0553)$ & $(0.0444)$ & $(0.0717)$ & $(0.3849)$ & $(0.5725)$ & $(0.4128)$ \\
Buddhist & $-0.0246^{*}$ & $0.0285^{*}$ & -0.0154 & 0.0039 & -0.0115 & -0.0027 \\
Others & $(0.0135)$ & $(0.0149)$ & $(0.0162)$ & $(0.7985)$ & $(0.4591)$ & $(0.7584)$ \\
& $-0.0734^{* * *}$ & $0.0712^{* * *}$ & $-0.0305^{*}$ & -0.0022 & $-0.0327^{*}$ & $-0.0147^{*}$ \\
& $(0.0208)$ & $(0.0205)$ & $(0.0164)$ & $(0.9128)$ & $(0.0777)$ & $(0.0539)$ \\
& -0.0154 & -0.0003 & 0.0102 & -0.0157 & -0.0055 & -0.0028 \\
& $0.0218^{* * *}$ & $(0.0230)$ & $(0.0642)$ & $(0.6525)$ & $(0.9317)$ & $(0.8590)$ \\
\hline
\end{tabular}

B. Intolerance towards immigrants and other races (N. of observations: 84,$179 ; R^{2}: 0.272$ )

\begin{tabular}{lcccccc}
\hline & $\begin{array}{c}\text { Raised } \\
\text { religiously }\end{array}$ & $\begin{array}{c}\text { Currently } \\
\text { religious }\end{array}$ & $\begin{array}{c}\text { Actively } \\
\text { religious }\end{array}$ & $\begin{array}{c}\text { Raised religiously } \\
\text { +Currently } \\
\text { Religious }\end{array}$ & $\begin{array}{c}\text { Raised religiously } \\
\text { +Currently } \\
\text { Religious } \\
\text { Actively Religious }\end{array}$ & $\begin{array}{c}\text { Total weighted } \\
\text { impact of religion }\end{array}$ \\
\hline Catholic & 0.0030 & $0.0193^{* * *}$ & 0.0027 & $0.0223^{* * *}$ & $0.0250^{* * * *}$ & $0.0177^{* * * *}$ \\
Protestant & $(0.0029)$ & $(0.0029)$ & $(0.0030)$ & $(0.0000)$ & $(0.0000)$ & $(0.0000)$ \\
& -0.0002 & $0.0136^{* * *}$ & 0.0051 & $0.0134^{* * *}$ & $0.0185^{* * *}$ & $0.0093^{* * *}$ \\
Jew & $(0.0041)$ & $(0.0037)$ & $(0.0055)$ & $(0.0028)$ & $(0.0006)$ & $(0.0000)$ \\
& 0.0116 & 0.0367 & -0.0200 & $0.0483^{*}$ & 0.0283 & $0.0228^{*}$ \\
Muslim & $(0.0290)$ & $(0.0231)$ & $(0.0377)$ & $(0.0782)$ & $(0.4327)$ & $(0.0546)$ \\
& $0.0145^{* *}$ & $0.0437^{* * *}$ & $0.0184^{* *}$ & $0.0582^{* * *}$ & $0.0766^{* * *}$ & $0.0458^{* * *}$ \\
Hindu & $(0.0071)$ & $(0.0079)$ & $(0.0085)$ & $(0.0000)$ & $(0.0000)$ & $(0.0000)$ \\
& $0.0978^{* * *}$ & 0.0175 & -0.0023 & $0.1153^{* * *}$ & $0.1130^{* * *}$ & $0.0958^{* * *}$ \\
Buddhist & $(0.0109)$ & $(0.0107)$ & $(0.0085)$ & $(0.0000)$ & $(0.0000)$ & $(0.0000)$ \\
Others & $0.0355^{*}$ & $-0.0452^{* * * *}$ & $0.0600^{*}$ & -0.0097 & 0.0503 & $-0.0214^{* * *}$ \\
& $(0.0185)$ & $(0.0120)$ & $(0.0333)$ & $(0.5954)$ & $(0.1344)$ & $(0.0094)$ \\
& $0.0127^{* * *}$ & 0.0031 & $-0.0143^{* *}$ & $0.0158^{* * *}$ & 0.0015 & $0.0062^{* *}$ \\
\hline
\end{tabular}


C. Trust the government (N. of observations: 47,$\left.667 ; \mathrm{R}^{2}: 0.133\right)$

\begin{tabular}{|c|c|c|c|c|c|c|}
\hline & $\begin{array}{l}\text { Raised } \\
\text { religiously }\end{array}$ & $\begin{array}{l}\text { Currently } \\
\text { religious }\end{array}$ & $\begin{array}{l}\text { Actively } \\
\text { religious }\end{array}$ & $\begin{array}{l}\text { Raised religiously } \\
+ \text { Currently Religious }\end{array}$ & $\begin{array}{c}\text { Raised religiously } \\
\text { +Currently Religious }+ \\
\text { Actively Religious }\end{array}$ & $\begin{array}{c}\text { Total weighted impact } \\
\text { of religion }\end{array}$ \\
\hline Catholic & $\begin{array}{c}0.0059 \\
(0.0157)\end{array}$ & $\begin{array}{c}0.1218 * * * \\
(0.0160)\end{array}$ & $\begin{array}{c}0.0328^{* *} \\
(0.0162)\end{array}$ & $\begin{array}{l}0.1277^{* * *} \\
(0.0000)\end{array}$ & $\begin{array}{l}0.1605^{* * *} \\
(0.0000)\end{array}$ & $\begin{array}{l}0.1086^{* * *} \\
(0.0000)\end{array}$ \\
\hline Protestant & $\begin{array}{c}0.0044 \\
(0.0224)\end{array}$ & $\begin{array}{l}0.0920 * * * \\
(0.0234)\end{array}$ & $\begin{array}{c}0.0324 \\
(0.0321)\end{array}$ & $\begin{array}{l}0.0964^{* * *} \\
(0.0001)\end{array}$ & $\begin{array}{l}0.1288^{* * *} \\
(0.0000)\end{array}$ & $\begin{array}{l}0.0649^{* * *} \\
(0.0000)\end{array}$ \\
\hline Jew & $\begin{array}{c}0.1309 \\
(0.1408)\end{array}$ & $\begin{array}{l}-0.0096 \\
(0.1270)\end{array}$ & $\begin{array}{c}0.0235 \\
(0.2098)\end{array}$ & $\begin{array}{c}0.1213 \\
(0.3150)\end{array}$ & $\begin{array}{c}0.1448 \\
(0.4312)\end{array}$ & $\begin{array}{c}0.0568 \\
(0.2833)\end{array}$ \\
\hline Muslim & $\begin{array}{c}0.1285^{* * * *} \\
(0.0277)\end{array}$ & $\begin{array}{l}0.0698 * * \\
(0.0306)\end{array}$ & $\begin{array}{c}0.1065 * * * \\
(0.0324)\end{array}$ & $\begin{array}{l}0.1983^{* * *} \\
(0.0000)\end{array}$ & $\begin{array}{l}0.3048^{* * *} \\
(0.0000)\end{array}$ & $\begin{array}{l}0.1713^{* * *} \\
(0.0000)\end{array}$ \\
\hline Hindu & $\begin{array}{l}0.0757^{*} \\
(0.0446)\end{array}$ & $\begin{array}{c}0.1835 * * * \\
(0.0466)\end{array}$ & $\begin{array}{c}0.0023 \\
(0.0338)\end{array}$ & $\begin{array}{l}0.2592^{* * *} \\
(0.0000)\end{array}$ & $\begin{array}{l}0.2615^{* * *} \\
(0.0000)\end{array}$ & $\begin{array}{l}0.2199^{* * *} \\
(0.0000)\end{array}$ \\
\hline Buddhist & $\begin{array}{c}0.2378 \\
(0.1498)\end{array}$ & $\begin{array}{l}-0.0272 \\
(0.1539)\end{array}$ & $\begin{array}{l}-0.0841 \\
(0.2139)\end{array}$ & $\begin{array}{c}0.2106 \\
(0.1487)\end{array}$ & $\begin{array}{c}0.1265 \\
(0.4733)\end{array}$ & $\begin{array}{c}0.0252 \\
(0.7885)\end{array}$ \\
\hline Others & $\begin{array}{l}0.0958^{* * * *} \\
(0.0186)\end{array}$ & $\begin{array}{l}-0.0080 \\
(0.0178)\end{array}$ & $\begin{array}{c}0.0210 \\
(0.0286)\end{array}$ & $\begin{array}{l}0.0878^{* * *} \\
(0.0000)\end{array}$ & $\begin{array}{l}0.1088^{* * *} \\
(0.0001)\end{array}$ & $\begin{array}{l}0.0470^{* * *} \\
(0.0000)\end{array}$ \\
\hline
\end{tabular}

D. Men deserve scarce jobs more than women (N. of observations: 72,$186 ; R^{2}: 0.139$ )

\begin{tabular}{|c|c|c|c|c|c|c|}
\hline & $\begin{array}{l}\text { Raised } \\
\text { religiously }\end{array}$ & $\begin{array}{l}\text { Currently } \\
\text { religious }\end{array}$ & $\begin{array}{l}\text { Actively } \\
\text { religious }\end{array}$ & $\begin{array}{c}\text { Raised religiously } \\
+ \text { Currently Religious }\end{array}$ & $\begin{array}{c}\text { Raised religiously } \\
\text { +Currently Religious }+ \\
\text { Actively Religious }\end{array}$ & $\begin{array}{c}\text { Total weighted impact } \\
\text { of religion }\end{array}$ \\
\hline Catholic & $\begin{array}{c}0.0700 * * * \\
(0.0121)\end{array}$ & $\begin{array}{l}-0.0028 \\
(0.0123)\end{array}$ & $\begin{array}{c}0.0634 * * * \\
(0.0120)\end{array}$ & $\begin{array}{l}0.0672^{* * *} \\
(0.0000)\end{array}$ & $\begin{array}{c}0.1306^{* * *} \\
(0.0000)\end{array}$ & $\begin{array}{l}0.0717^{* * *} \\
(0.0000)\end{array}$ \\
\hline Protestant & $\begin{array}{c}0.0907 * * * \\
(0.0168)\end{array}$ & $\begin{array}{l}-0.0094 \\
(0.0176)\end{array}$ & $\begin{array}{c}0.0987 * * * \\
(0.0250)\end{array}$ & $\begin{array}{l}0.0813^{* * *} \\
(0.0000)\end{array}$ & $\begin{array}{l}0.1800^{* * *} \\
(0.0000)\end{array}$ & $\begin{array}{l}0.0621^{* * *} \\
(0.0000)\end{array}$ \\
\hline Jew & $\begin{array}{l}-0.1024 \\
(0.1254)\end{array}$ & $\begin{array}{l}-0.0272 \\
(0.1168)\end{array}$ & $\begin{array}{c}0.1900 \\
(0.1912)\end{array}$ & $\begin{array}{l}-0.1296 \\
(0.2442)\end{array}$ & $\begin{array}{c}0.0604 \\
(0.7185)\end{array}$ & $\begin{array}{l}-0.0300 \\
(0.5396)\end{array}$ \\
\hline Muslim & $\begin{array}{c}0.0706 * * * \\
(0.0271)\end{array}$ & $\begin{array}{c}0.1658^{* * *} \\
(0.0302)\end{array}$ & $\begin{array}{c}0.0963 * * * \\
(0.0322)\end{array}$ & $\begin{array}{l}0.2364^{* * *} \\
(0.0000)\end{array}$ & $\begin{array}{c}0.3327^{* * *} \\
(0.0000)\end{array}$ & $\begin{array}{l}0.1936^{* * *} \\
(0.0000)\end{array}$ \\
\hline Hindu & $\begin{array}{c}0.1270 * * * \\
(0.0445)\end{array}$ & $\begin{array}{l}-0.0399 \\
(0.0463)\end{array}$ & $\begin{array}{l}0.0612 * \\
(0.0336)\end{array}$ & $\begin{array}{l}0.0871^{* *} \\
(0.0330)\end{array}$ & $\begin{array}{l}0.1483^{* * *} \\
(0.0001)\end{array}$ & $\begin{array}{l}0.0998^{* * *} \\
(0.0001)\end{array}$ \\
\hline Buddhist & $\begin{array}{l}-0.0142 \\
(0.0844)\end{array}$ & $\begin{array}{c}0.0885 \\
(0.0752)\end{array}$ & $\begin{array}{c}0.0863 \\
(0.1599)\end{array}$ & $\begin{array}{c}0.0743 \\
(0.3133)\end{array}$ & $\begin{array}{c}0.1606 \\
(0.2892)\end{array}$ & $\begin{array}{c}0.0711 \\
(0.1235)\end{array}$ \\
\hline Others & $\begin{array}{c}0.0112 \\
(0.0172)\end{array}$ & $\begin{array}{c}0.0052 \\
(0.0168)\end{array}$ & $\begin{array}{l}0.0458^{*} \\
(0.0257)\end{array}$ & $\begin{array}{c}0.0164 \\
(0.3765)\end{array}$ & $\begin{array}{l}0.0622^{* *} \\
(0.0105)\end{array}$ & $\begin{array}{l}0.0170^{*} \\
(0.0926)\end{array}$ \\
\hline
\end{tabular}

E. Men deserve university education more than women ( $N$. of observations: 38,$148 ; R^{2}: 0.123$ )

\begin{tabular}{|c|c|c|c|c|c|c|}
\hline & $\begin{array}{l}\text { Raised } \\
\text { religiously }\end{array}$ & $\begin{array}{l}\text { Currently } \\
\text { religious }\end{array}$ & $\begin{array}{l}\text { Actively } \\
\text { religious }\end{array}$ & $\begin{aligned} & \text { Raised religiously } \\
+ & \text { Currently Religious }\end{aligned}$ & $\begin{array}{c}\text { Raised religiously } \\
+ \text { Currently Religious }+ \\
\text { Actively Religious }\end{array}$ & $\begin{array}{c}\text { Total weighted impact } \\
\text { of religion }\end{array}$ \\
\hline Catholic & $\begin{array}{l}0.0309^{*} \\
(0.0171)\end{array}$ & $\begin{array}{c}0.0174 \\
(0.0173)\end{array}$ & $\begin{array}{l}0.0396^{* *} \\
(0.0165)\end{array}$ & $\begin{array}{l}0.0483^{* * *} \\
(0.0051)\end{array}$ & $\begin{array}{l}0.0879^{* * * *} \\
(0.0000)\end{array}$ & $\begin{array}{l}0.0502^{* * *} \\
(0.0000)\end{array}$ \\
\hline Protestant & $\begin{array}{c}0.0285 \\
(0.0253)\end{array}$ & $\begin{array}{c}0.0175 \\
(0.0267)\end{array}$ & $\begin{array}{c}0.0595 \\
(0.0379)\end{array}$ & $\begin{array}{c}0.0460 \\
(0.1030)\end{array}$ & $\begin{array}{l}0.1055^{* * *} \\
(0.0014)\end{array}$ & $\begin{array}{l}0.0388^{* * *} \\
(0.0028)\end{array}$ \\
\hline Jew & $\begin{array}{c}0.0978 \\
(0.1635)\end{array}$ & $\begin{array}{c}0.0177 \\
(0.1416)\end{array}$ & $\begin{array}{l}-0.4662 * \\
(0.2636)\end{array}$ & $\begin{array}{c}0.1155 \\
(0.4107)\end{array}$ & $\begin{array}{l}-0.3507 \\
(0.1319)\end{array}$ & $\begin{array}{l}-0.0227 \\
(0.7174)\end{array}$ \\
\hline Muslim & $\begin{array}{l}-0.0180 \\
(0.0277)\end{array}$ & $\begin{array}{c}0.0323 \\
(0.0304)\end{array}$ & $\begin{array}{c}0.2072 * * * \\
(0.0326)\end{array}$ & $\begin{array}{c}0.0143 \\
(0.6507)\end{array}$ & $\begin{array}{l}0.2215^{* * *} \\
(0.0000)\end{array}$ & $\begin{array}{l}0.0812^{* * *} \\
(0.0000)\end{array}$ \\
\hline Hindu & $\begin{array}{l}-0.0055 \\
(0.0625)\end{array}$ & $\begin{array}{l}0.1488 * * \\
(0.0677)\end{array}$ & $\begin{array}{c}-0.1417 * * \\
(0.0551)\end{array}$ & $\begin{array}{l}0.1433^{* *} \\
(0.0108)\end{array}$ & $\begin{array}{c}0.0016 \\
(0.9747)\end{array}$ & $\begin{array}{c}0.0585 \\
(0.3542)\end{array}$ \\
\hline Buddhist & $\begin{array}{c}0.2190 \\
(0.2473)\end{array}$ & $\begin{array}{l}-0.0893 \\
(0.2489)\end{array}$ & $\begin{array}{c}0.0078 \\
(0.3009)\end{array}$ & $\begin{array}{c}0.1297 \\
(0.5674)\end{array}$ & $\begin{array}{c}0.1375 \\
(0.5659)\end{array}$ & $\begin{array}{l}-0.0184 \\
(0.9016)\end{array}$ \\
\hline Others & $\begin{array}{c}0.0021 \\
(0.0201)\end{array}$ & $\begin{array}{c}0.0120 \\
(0.0191)\end{array}$ & $\begin{array}{l}-0.0209 \\
(0.0306)\end{array}$ & $\begin{array}{c}0.0141 \\
(0.5188)\end{array}$ & $\begin{array}{l}-0.0068 \\
(0.8132)\end{array}$ & $\begin{array}{c}0.0057 \\
(0.6347)\end{array}$ \\
\hline
\end{tabular}


F. Trust in the legal system (N. of observations: 88,$157 ; R^{2}: 0.092$ )

\begin{tabular}{|c|c|c|c|c|c|c|}
\hline & $\begin{array}{l}\text { Raised } \\
\text { religiously }\end{array}$ & $\begin{array}{l}\text { Currently } \\
\text { religious }\end{array}$ & $\begin{array}{l}\text { Actively } \\
\text { religious }\end{array}$ & $\begin{array}{c}\text { Raised religiously } \\
+ \text { Currently Religious }\end{array}$ & $\begin{array}{c}\text { Raised religiously } \\
+ \text { Currently Religious }+ \\
\text { Actively Religious }\end{array}$ & $\begin{array}{c}\text { Total weighted impact } \\
\text { of religion }\end{array}$ \\
\hline Catholic & $\begin{array}{c}0.0285^{* * * *} \\
(0.0103)\end{array}$ & $\begin{array}{c}0.0973 * * * \\
(0.0102)\end{array}$ & $\begin{array}{c}0.0820 * * * \\
(0.0104)\end{array}$ & $\begin{array}{l}0.1258^{* * *} \\
(0.0000)\end{array}$ & $\begin{array}{l}0.2078^{* * * *} \\
(0.0000)\end{array}$ & $\begin{array}{l}0.1251^{* * *} \\
(0.0000)\end{array}$ \\
\hline Protestant & $\begin{array}{c}0.0430 * * * \\
(0.0146)\end{array}$ & $\begin{array}{c}0.0801 * * * \\
(0.0133)\end{array}$ & $\begin{array}{c}0.0664 * * * \\
(0.0195)\end{array}$ & $\begin{array}{l}0.1231^{* * *} \\
(0.0000)\end{array}$ & $\begin{array}{l}0.1895^{* * *} \\
(0.0000)\end{array}$ & $\begin{array}{l}0.0846^{* * *} \\
(0.0000)\end{array}$ \\
\hline Jew & $\begin{array}{c}0.1714 \\
(0.1065)\end{array}$ & $\begin{array}{l}0.0410 \\
(0.0857)\end{array}$ & $\begin{array}{c}0.0530 \\
(0.1382)\end{array}$ & $\begin{array}{l}0.2124^{* *} \\
(0.0354)\end{array}$ & $\begin{array}{l}0.2654^{* *} \\
(0.0441)\end{array}$ & $\begin{array}{l}0.1085^{* *} \\
(0.0128)\end{array}$ \\
\hline Muslim & $\begin{array}{c}0.1599 * * * \\
(0.0262)\end{array}$ & $\begin{array}{l}0.0582 * * \\
(0.0289)\end{array}$ & $\begin{array}{c}0.0398 \\
(0.0311)\end{array}$ & $\begin{array}{l}0.2181^{* * *} \\
(0.0000)\end{array}$ & $\begin{array}{l}0.2579^{* * * *} \\
(0.0000)\end{array}$ & $\begin{array}{l}0.1618^{* * * *} \\
(0.0000)\end{array}$ \\
\hline Hindu & $\begin{array}{c}0.0232 \\
(0.0400)\end{array}$ & $\begin{array}{l}0.0883 * * \\
(0.0393)\end{array}$ & $\begin{array}{l}-0.0351 \\
(0.0315)\end{array}$ & $\begin{array}{l}0.1115^{* * *} \\
(0.0040)\end{array}$ & $\begin{array}{l}0.0764^{* *} \\
(0.0315)\end{array}$ & $\begin{array}{l}0.0786^{* *} \\
(0.0169)\end{array}$ \\
\hline Buddhist & $\begin{array}{c}0.2387 * * * \\
(0.0677)\end{array}$ & $\begin{array}{c}0.0619 \\
(0.0440)\end{array}$ & $\begin{array}{l}0.0780 \\
(0.1217)\end{array}$ & $\begin{array}{l}0.3006^{* * *} \\
(0.0000)\end{array}$ & $\begin{array}{l}0.3786^{* * *} \\
(0.0020)\end{array}$ & $\begin{array}{l}0.1064^{* * *} \\
(0.0004)\end{array}$ \\
\hline Others & $\begin{array}{c}0.0698 * * * \\
(0.0165)\end{array}$ & $\begin{array}{l}0.0335 * * \\
(0.0159)\end{array}$ & $\begin{array}{c}0.0490^{* *} \\
(0.0243)\end{array}$ & $\begin{array}{l}0.1033^{* * *} \\
(0.0000)\end{array}$ & $\begin{array}{l}0.1523^{* * *} \\
(0.0000)\end{array}$ & $\begin{array}{l}0.0668^{* * *} \\
(0.0000)\end{array}$ \\
\hline
\end{tabular}

G. Is it justified to cheat on taxes? (N. of observations: $86,627=; \mathrm{R}^{2}: 0.098$ )

\begin{tabular}{|c|c|c|c|c|c|c|}
\hline & $\begin{array}{l}\text { Raised } \\
\text { religiously }\end{array}$ & $\begin{array}{l}\text { Currently } \\
\text { religious }\end{array}$ & $\begin{array}{l}\text { Actively } \\
\text { religious }\end{array}$ & $\begin{array}{c}\text { Raised religiously } \\
\text { +Currently } \\
\text { Religious }\end{array}$ & $\begin{array}{c}\text { Raised religiously } \\
+ \text { Currently } \\
\text { Religious }+ \\
\text { Actively Religious }\end{array}$ & $\begin{array}{l}\text { Total weighted } \\
\text { impact of religion }\end{array}$ \\
\hline Catholic & $\begin{array}{c}-0.1529 * * * \\
(0.0295)\end{array}$ & $\begin{array}{c}-0.0615^{* *} \\
(0.0291)\end{array}$ & $\begin{array}{c}-0.2109 * * * \\
(0.0296)\end{array}$ & $\begin{array}{c}-0.2144^{* * * *} \\
(0.0000)\end{array}$ & $\begin{array}{c}-0.4253^{* * *} \\
(0.0000)\end{array}$ & $\begin{array}{c}-0.2356^{* * *} \\
(0.0000)\end{array}$ \\
\hline Protestant & $\begin{array}{c}-0.1355^{* * *} \\
(0.0418)\end{array}$ & $\begin{array}{c}-0.2443 * * * \\
(0.0378)\end{array}$ & $\begin{array}{c}-0.4312 * * * \\
(0.0557)\end{array}$ & $\begin{array}{c}-0.3798^{* * *} \\
(0.0000)\end{array}$ & $\begin{array}{c}-0.8110^{* * *} \\
(0.0000)\end{array}$ & $\begin{array}{c}-0.3174^{* * *} \\
(0.0000)\end{array}$ \\
\hline Jew & $\begin{array}{l}-0.4927^{*} \\
(0.2990)\end{array}$ & $\begin{array}{c}0.0924 \\
(0.2409)\end{array}$ & $\begin{array}{c}-1.1119 * * * \\
(0.3899)\end{array}$ & $\begin{array}{l}-0.4003 \\
(0.1588)\end{array}$ & $\begin{array}{c}-1.5122^{* * *} \\
(0.0001)\end{array}$ & $\begin{array}{c}-0.3494^{* * *} \\
(0.0045)\end{array}$ \\
\hline Muslim & $\begin{array}{c}-0.2685 * * * \\
(0.0899)\end{array}$ & $\begin{array}{c}0.0348 \\
(0.0950)\end{array}$ & $\begin{array}{c}0.0118 \\
(0.1042)\end{array}$ & $\begin{array}{c}-0.2337^{* *} \\
(0.0112)\end{array}$ & $\begin{array}{l}-0.2219^{* *} \\
(0.0247)\end{array}$ & $\begin{array}{c}-0.1546^{* * *} \\
(0.0045)\end{array}$ \\
\hline Hindu & $\begin{array}{l}-0.0187 \\
(0.1144)\end{array}$ & $\begin{array}{c}-0.3074 * * * \\
(0.1121)\end{array}$ & $\begin{array}{l}-0.0828 \\
(0.0895)\end{array}$ & $\begin{array}{c}-0.3261^{* * *} \\
(0.0034)\end{array}$ & $\begin{array}{c}-0.4089^{* * *} \\
(0.0001)\end{array}$ & $\begin{array}{c}-0.3128^{* * *} \\
(0.0007)\end{array}$ \\
\hline Buddhist & $\begin{array}{c}0.0372 \\
(0.1931)\end{array}$ & $\begin{array}{c}0.0428 \\
(0.1280)\end{array}$ & $\begin{array}{l}-0.3887 \\
(0.3542)\end{array}$ & $\begin{array}{c}0.0800 \\
(0.6754)\end{array}$ & $\begin{array}{l}-0.3087 \\
(0.3841)\end{array}$ & $\begin{array}{c}0.0084 \\
(0.9233)\end{array}$ \\
\hline Others & $\begin{array}{c}-0.1278 * * * \\
(0.0474)\end{array}$ & $\begin{array}{l}0.1126 * * \\
(0.0457)\end{array}$ & $\begin{array}{c}-0.4630 * * * \\
(0.0696)\end{array}$ & $\begin{array}{l}-0.0152 \\
(0.7662)\end{array}$ & $\begin{array}{c}-0.4782^{* * *} \\
(0.0000)\end{array}$ & $\begin{array}{c}-0.0671^{* *} \\
(0.0153)\end{array}$ \\
\hline
\end{tabular}

H. Is it justified to accept a bribe? (N. of observations: $87,082=; \mathrm{R}^{2}: 0.069$ )

\begin{tabular}{|c|c|c|c|c|c|c|}
\hline & $\begin{array}{l}\text { Raised } \\
\text { religiously }\end{array}$ & $\begin{array}{l}\text { Currently } \\
\text { religious }\end{array}$ & $\begin{array}{l}\text { Actively } \\
\text { religious }\end{array}$ & $\begin{array}{c}\text { Raised religiously } \\
+ \text { Currently Religious }\end{array}$ & $\begin{array}{c}\text { Raised religiously } \\
\text { +Currently Religious }+ \\
\text { Actively Religious }\end{array}$ & $\begin{array}{c}\text { Total weighted impact } \\
\text { of religion }\end{array}$ \\
\hline Catholic & $\begin{array}{c}-0.0814 * * * \\
(0.0200)\end{array}$ & $\begin{array}{l}0.0333 * \\
(0.0197)\end{array}$ & $\begin{array}{c}-0.0764 * * * \\
(0.0201)\end{array}$ & $\begin{array}{l}-0.0481^{* *} \\
(0.0276)\end{array}$ & $\begin{array}{c}-0.1245^{* * *} \\
(0.0000)\end{array}$ & $\begin{array}{c}-0.0618^{* * *} \\
(0.0000)\end{array}$ \\
\hline Protestant & $\begin{array}{c}0.0251 \\
(0.0283)\end{array}$ & $\begin{array}{c}-0.0608^{* *} \\
(0.0256)\end{array}$ & $\begin{array}{c}-0.1846^{* * * *} \\
(0.0378)\end{array}$ & $\begin{array}{l}-0.0357 \\
(0.2545)\end{array}$ & $\begin{array}{c}-0.2203^{* * *} \\
(0.0000)\end{array}$ & $\begin{array}{c}-0.0704^{* * *} \\
(0.0000)\end{array}$ \\
\hline Jew & $\begin{array}{l}-0.0348 \\
(0.2047)\end{array}$ & $\begin{array}{c}0.0263 \\
(0.1645)\end{array}$ & $\begin{array}{l}-0.2133 \\
(0.2706)\end{array}$ & $\begin{array}{l}-0.0085 \\
(0.9651)\end{array}$ & $\begin{array}{l}-0.2218 \\
(0.3915)\end{array}$ & $\begin{array}{l}-0.0355 \\
(0.6743)\end{array}$ \\
\hline Muslim & $\begin{array}{c}0.4354 * * * \\
(0.0605)\end{array}$ & $\begin{array}{c}-0.6909 * * * \\
(0.0640)\end{array}$ & $\begin{array}{l}-0.0084 \\
(0.0701)\end{array}$ & $\begin{array}{c}-0.2555^{* * *} \\
(0.0000)\end{array}$ & $\begin{array}{l}-0.2639^{* * *} \\
(0.0001)\end{array}$ & $\begin{array}{c}-0.1757^{* * *} \\
(0.0000)\end{array}$ \\
\hline Hindu & $\begin{array}{l}-0.0915 \\
(0.0774)\end{array}$ & $\begin{array}{l}-0.1132 \\
(0.0757)\end{array}$ & $\begin{array}{c}0.0709 \\
(0.0606)\end{array}$ & $\begin{array}{c}-0.2047^{* * *} \\
(0.0067)\end{array}$ & $\begin{array}{l}-0.1338^{*} \\
(0.0538)\end{array}$ & $\begin{array}{l}-0.1411^{* *} \\
(0.0193)\end{array}$ \\
\hline Buddhist & $\begin{array}{l}-0.0233 \\
(0.1314)\end{array}$ & $\begin{array}{l}-0.0198 \\
(0.0868)\end{array}$ & $\begin{array}{l}-0.4060^{*} \\
(0.2379)\end{array}$ & $\begin{array}{l}-0.0431 \\
(0.7401)\end{array}$ & $\begin{array}{l}-0.4491^{*} \\
(0.0600)\end{array}$ & $\begin{array}{l}-0.0539 \\
(0.3649)\end{array}$ \\
\hline Others & $\begin{array}{l}-0.0586^{*} \\
(0.0317)\end{array}$ & $\begin{array}{c}0.0257 \\
(0.0306)\end{array}$ & $\begin{array}{c}-0.1924 * * * \\
(0.0467)\end{array}$ & $\begin{array}{l}-0.0329 \\
(0.3371)\end{array}$ & $\begin{array}{c}-0.2253^{* * *} \\
(0.0000)\end{array}$ & $\begin{array}{l}-0.0451^{* *} \\
(0.0152)\end{array}$ \\
\hline
\end{tabular}


I. Accept more income inequality to provide incentives? (N. of obs.: $69,016=; R^{2}: 0.095$ )

\begin{tabular}{|c|c|c|c|c|c|c|}
\hline & $\begin{array}{l}\text { Raised } \\
\text { religiously }\end{array}$ & $\begin{array}{l}\text { Currently } \\
\text { religious }\end{array}$ & $\begin{array}{l}\text { Actively } \\
\text { religious }\end{array}$ & $\begin{aligned} & \text { Raised religiously } \\
+ & \text { Currently Religious }\end{aligned}$ & $\begin{array}{c}\text { Raised religiously } \\
\text { +Currently Religious }+ \\
\text { Actively Religious }\end{array}$ & $\begin{array}{c}\text { Total weighted impact } \\
\text { of religion }\end{array}$ \\
\hline Catholic & $\begin{array}{l}-0.0100 \\
(0.0404)\end{array}$ & $\begin{array}{l}-0.0290 \\
(0.0413)\end{array}$ & $\begin{array}{l}-0.0050 \\
(0.0411)\end{array}$ & $\begin{array}{l}-0.0390 \\
(0.3438)\end{array}$ & $\begin{array}{l}-0.0440 \\
(0.3070)\end{array}$ & $\begin{array}{l}-0.0308 \\
(0.2496)\end{array}$ \\
\hline Protestant & $\begin{array}{c}0.0272 \\
(0.0550)\end{array}$ & $\begin{array}{l}-0.0612 \\
(0.0572)\end{array}$ & $\begin{array}{l}0.1821 * * \\
(0.0831)\end{array}$ & $\begin{array}{l}-0.0340 \\
(0.5690)\end{array}$ & $\begin{array}{l}0.1481^{* *} \\
(0.0474)\end{array}$ & $\begin{array}{c}0.0220 \\
(0.4393)\end{array}$ \\
\hline Jew & $\begin{array}{l}-0.6147 \\
(0.4297)\end{array}$ & $\begin{array}{c}0.3402 \\
(0.3864)\end{array}$ & $\begin{array}{l}-1.0308 \\
(0.6403)\end{array}$ & $\begin{array}{l}-0.2745 \\
(0.4471)\end{array}$ & $\begin{array}{l}-1.3053^{* *} \\
(0.0201)\end{array}$ & $\begin{array}{l}-0.2493 \\
(0.1164)\end{array}$ \\
\hline Muslim & $\begin{array}{c}-0.3547 * * * \\
(0.0900)\end{array}$ & $\begin{array}{l}-0.0402 \\
(0.1001)\end{array}$ & $\begin{array}{l}0.1807^{*} \\
(0.1058)\end{array}$ & $\begin{array}{l}-0.3949^{* * *} \\
(0.0001)\end{array}$ & $\begin{array}{l}-0.2142^{* *} \\
(0.0359)\end{array}$ & $\begin{array}{l}-0.2058^{* * * *} \\
(0.0004)\end{array}$ \\
\hline Hindu & $\begin{array}{l}0.2512^{*} \\
(0.1443)\end{array}$ & $\begin{array}{l}-0.0920 \\
(0.1510)\end{array}$ & $\begin{array}{l}0.0509 \\
(0.1106)\end{array}$ & $\begin{array}{c}0.1592 \\
(0.2333)\end{array}$ & $\begin{array}{l}0.2101^{*} \\
(0.0903)\end{array}$ & $\begin{array}{l}0.1552^{*} \\
(0.0598)\end{array}$ \\
\hline Buddhist & $\begin{array}{l}-0.3905 \\
(0.2782)\end{array}$ & $\begin{array}{c}0.2837 \\
(0.2515)\end{array}$ & $\begin{array}{c}0.1453 \\
(0.5138)\end{array}$ & $\begin{array}{l}-0.1068 \\
(0.6641)\end{array}$ & $\begin{array}{c}0.0385 \\
(0.9373)\end{array}$ & $\begin{array}{c}0.1404 \\
(0.3622)\end{array}$ \\
\hline Others & $\begin{array}{c}-0.2158^{* * *} \\
(0.0563)\end{array}$ & $\begin{array}{c}0.0053 \\
(0.0548)\end{array}$ & $\begin{array}{c}0.0813 \\
(0.0844)\end{array}$ & $\begin{array}{l}-0.2105^{* * *} \\
(0.0005)\end{array}$ & $\begin{array}{l}-0.1292 \\
(0.1051)\end{array}$ & $\begin{array}{l}-0.0926^{* * *} \\
(0.0052)\end{array}$ \\
\hline
\end{tabular}

J. Private ownership should be increased? (N. of obs.: $66,833=; \mathrm{R}^{2}: 0.133$ )

\begin{tabular}{|c|c|c|c|c|c|c|}
\hline & $\begin{array}{l}\text { Raised } \\
\text { religiously }\end{array}$ & $\begin{array}{l}\text { Currently } \\
\text { religious }\end{array}$ & $\begin{array}{l}\text { Actively } \\
\text { religious }\end{array}$ & $\begin{aligned} & \text { Raised religiously } \\
+ & \text { Currently Religious }\end{aligned}$ & $\begin{array}{c}\text { Raised religiously } \\
\text { +Currently Religious }+ \\
\text { Actively Religious }\end{array}$ & $\begin{array}{c}\text { Total weighted impact } \\
\text { of religion }\end{array}$ \\
\hline Catholic & $\begin{array}{l}-0.0252 \\
(0.0389)\end{array}$ & $\begin{array}{c}0.1683 * * * \\
(0.0399)\end{array}$ & $\begin{array}{c}0.1493 * * * \\
(0.0398)\end{array}$ & $\begin{array}{l}0.1431^{* * *} \\
(0.0003)\end{array}$ & $\begin{array}{l}0.2924^{* * * *} \\
(0.0000)\end{array}$ & $\begin{array}{l}0.1669^{* * *} \\
(0.0000)\end{array}$ \\
\hline Protestant & $\begin{array}{c}0.1659 * * * \\
(0.0524)\end{array}$ & $\begin{array}{c}0.0653 \\
(0.0544)\end{array}$ & $\begin{array}{l}-0.0658 \\
(0.0793)\end{array}$ & $\begin{array}{l}0.2312^{* * *} \\
(0.0000)\end{array}$ & $\begin{array}{l}0.1654^{* * *} \\
(0.0205)\end{array}$ & $\begin{array}{l}0.1010^{* * *} \\
(0.0002)\end{array}$ \\
\hline Jew & $\begin{array}{l}-0.0314 \\
(0.3951)\end{array}$ & $\begin{array}{l}-0.3337 \\
(0.3604)\end{array}$ & $\begin{array}{c}0.5569 \\
(0.6107)\end{array}$ & $\begin{array}{l}-0.3651 \\
(0.2795)\end{array}$ & $\begin{array}{c}0.1918 \\
(0.7218)\end{array}$ & $\begin{array}{l}-0.1129 \\
(0.4538)\end{array}$ \\
\hline Muslim & $\begin{array}{l}-0.0996 \\
(0.0835)\end{array}$ & $\begin{array}{l}0.1802 * \\
(0.0928)\end{array}$ & $\begin{array}{c}-0.2557 * * * \\
(0.0989)\end{array}$ & $\begin{array}{c}0.0806 \\
(0.3883)\end{array}$ & $\begin{array}{l}-0.1751^{*} \\
(0.0678)\end{array}$ & $\begin{array}{l}-0.0337 \\
(0.5389)\end{array}$ \\
\hline Hindu & $\begin{array}{c}0.4198 * * * \\
(0.1363)\end{array}$ & $\begin{array}{c}-0.5407 * * * \\
(0.1424)\end{array}$ & $\begin{array}{c}0.3825 * * * \\
(0.1042)\end{array}$ & $\begin{array}{l}-0.1209 \\
(0.3365)\end{array}$ & $\begin{array}{l}0.2616^{* *} \\
(0.0249)\end{array}$ & $\begin{array}{c}0.0636 \\
(0.0693)\end{array}$ \\
\hline Buddhist & $\begin{array}{l}-0.2157 \\
(0.2781)\end{array}$ & $\begin{array}{l}0.5095^{* *} \\
(0.2546)\end{array}$ & $\begin{array}{c}0.1453 \\
(0.5162)\end{array}$ & $\begin{array}{c}0.2938 \\
(0.2345)\end{array}$ & $\begin{array}{c}0.4391 \\
(0.3679)\end{array}$ & $\begin{array}{l}0.3504^{* * *} \\
(0.0246)\end{array}$ \\
\hline Others & $\begin{array}{c}-0.3254 * * * \\
(0.0532)\end{array}$ & $\begin{array}{l}-0.0060 \\
(0.0518)\end{array}$ & $\begin{array}{c}0.3951 * * * \\
(0.0798)\end{array}$ & $\begin{array}{c}-0.3314^{* * *} \\
(0.0000)\end{array}$ & $\begin{array}{c}0.0637 \\
(0.3989)\end{array}$ & $\begin{array}{c}-0.1029^{* * *} \\
(0.0011)\end{array}$ \\
\hline
\end{tabular}

K. Competition is good (N. of obs.: $\left.68,177=; R^{2}: 0.066\right)$

\begin{tabular}{|c|c|c|c|c|c|c|}
\hline & $\begin{array}{l}\text { Raised } \\
\text { religiously }\end{array}$ & $\begin{array}{l}\text { Currently } \\
\text { religious }\end{array}$ & $\begin{array}{l}\text { Actively } \\
\text { religious }\end{array}$ & $\begin{array}{l}\text { Raised religiously } \\
+ \text { Currently Religious }\end{array}$ & $\begin{array}{c}\text { Raised religiously } \\
+ \text { Currently Religious }+ \\
\text { Actively Religious }\end{array}$ & $\begin{array}{c}\text { Total weighted impact } \\
\text { of religion }\end{array}$ \\
\hline \multirow[t]{2}{*}{ Catholic } & $0.1536^{* * *}$ & -0.0258 & 0.0544 & $0.1278^{* * *}$ & $0.1822^{* * *}$ & $0.1097^{* * *}$ \\
\hline & $(0.0353)$ & $(0.0361)$ & $(0.0360)$ & $(0.0004)$ & $(0.0000)$ & $(0.0000)$ \\
\hline \multirow[t]{2}{*}{ Protestant } & $0.1043^{* *}$ & 0.0133 & -0.0758 & $0.1176^{* *}$ & 0.0418 & 0.0384 \\
\hline & $(0.0479)$ & $(0.0498)$ & $(0.0724)$ & $(0.0235)$ & $(0.5212)$ & $(0.1218)$ \\
\hline \multirow[t]{2}{*}{ Jew } & 0.1226 & 0.2360 & 0.1852 & 0.3586 & 0.5438 & 0.2196 \\
\hline & $(0.3687)$ & $(0.3339)$ & $(0.5556)$ & $(0.2510)$ & $(0.2643)$ & $(0.1116)$ \\
\hline \multirow[t]{2}{*}{ Muslim } & $-0.4988 * * *$ & $0.1883 * *$ & -0.0124 & $-0.3105^{* * *}$ & $-0.3229^{* * *}$ & $-0.2153^{* * *}$ \\
\hline & $(0.0773)$ & $(0.0861)$ & $(0.0914)$ & $(0.0003)$ & $(0.0003)$ & $(0.0000)$ \\
\hline \multirow[t]{2}{*}{ Hindu } & $-0.3992 * * *$ & -0.0494 & 0.0759 & $-0.4486^{* * *}$ & $-0.3727^{* * *}$ & $-0.3427^{* * *}$ \\
\hline & $(0.1253)$ & $(0.1309)$ & $(0.0957)$ & $(0.0001)$ & $(0.0005)$ & $(0.0000)$ \\
\hline \multirow[t]{2}{*}{ Buddhist } & -0.1674 & 0.3359 & $-0.8956^{* *}$ & 0.1685 & $-0.7271^{*}$ & 0.1431 \\
\hline & $(0.2410)$ & $(0.2172)$ & $(0.4516)$ & $(0.4303)$ & $(0.0900)$ & $(0.2837)$ \\
\hline \multirow[t]{2}{*}{ Others } & -0.0494 & 0.0352 & $-0.1921 * * *$ & -0.0142 & $-0.2063^{* * *}$ & -0.0338 \\
\hline & $(0.0494)$ & $(0.0481)$ & $(0.0742)$ & $(0.7895)$ & $(0.0032)$ & $(0.2447)$ \\
\hline
\end{tabular}


L. Thrift to be taught to children (N. of obs.: $88,696=; \mathrm{R}^{2}: 0.112$ )

\begin{tabular}{|c|c|c|c|c|c|c|}
\hline & $\begin{array}{l}\text { Raised } \\
\text { religiously }\end{array}$ & $\begin{array}{l}\text { Currently } \\
\text { religious }\end{array}$ & $\begin{array}{l}\text { Actively } \\
\text { religious }\end{array}$ & $\begin{aligned} & \text { Raised religiously } \\
+ & \text { Currently Religious }\end{aligned}$ & $\begin{array}{c}\text { Raised religiously } \\
+ \text { Currently Religious }+ \\
\text { Actively Religious }\end{array}$ & $\begin{array}{c}\text { Total weighted impact } \\
\text { of religion }\end{array}$ \\
\hline Catholic & $\begin{array}{c}0.0087 \\
(0.0055)\end{array}$ & $\begin{array}{c}0.0112^{* *} \\
(0.0054)\end{array}$ & $\begin{array}{l}-0.0061 \\
(0.0056)\end{array}$ & $\begin{array}{l}0.0199^{* * *} \\
(0.0009)\end{array}$ & $\begin{array}{l}0.0138^{* *} \\
(0.0266)\end{array}$ & $\begin{array}{l}0.0122^{* * *} \\
(0.0020)\end{array}$ \\
\hline Protestant & $\begin{array}{c}0.0115 \\
(0.0078)\end{array}$ & $\begin{array}{c}0.0174 * * \\
(0.0070)\end{array}$ & $\begin{array}{c}-0.0294 * * * \\
(0.0103)\end{array}$ & $\begin{array}{l}0.0289^{* * *} \\
(0.0008)\end{array}$ & $\begin{array}{l}-0.0005 \\
(0.9580)\end{array}$ & $\begin{array}{l}0.0085^{* *} \\
(0.0366)\end{array}$ \\
\hline Jew & $\begin{array}{c}0.0301 \\
(0.0557)\end{array}$ & $\begin{array}{c}0.0197 \\
(0.0447)\end{array}$ & $\begin{array}{l}-0.0251 \\
(0.0727)\end{array}$ & $\begin{array}{c}0.0498 \\
(0.3478)\end{array}$ & $\begin{array}{c}0.0247 \\
(0.7227)\end{array}$ & $\begin{array}{c}0.0205 \\
(0.3711)\end{array}$ \\
\hline Muslim & $\begin{array}{c}0.0574 * * * \\
(0.0137)\end{array}$ & $\begin{array}{c}-0.0310^{* *} \\
(0.0151)\end{array}$ & $\begin{array}{c}-0.0525^{* * * *} \\
(0.0163)\end{array}$ & $\begin{array}{l}0.0264^{*} \\
(0.0876)\end{array}$ & $\begin{array}{l}-0.0261 \\
(0.0987)\end{array}$ & $\begin{array}{l}-0.0002 \\
(0.9851)\end{array}$ \\
\hline Hindu & $\begin{array}{l}0.0352^{*} \\
(0.0210)\end{array}$ & $\begin{array}{c}0.0027 \\
(0.0207)\end{array}$ & $\begin{array}{l}-0.0197 \\
(0.0166)\end{array}$ & $\begin{array}{l}0.0379^{*} \\
(0.0634)\end{array}$ & $\begin{array}{c}0.0182 \\
(0.3322)\end{array}$ & $\begin{array}{c}0.0230 \\
(0.1086)\end{array}$ \\
\hline Buddhist & $\begin{array}{c}-0.0553 \\
(0.0356)\end{array}$ & $\begin{array}{c}0.0507 * * \\
(0.0232)\end{array}$ & $\begin{array}{l}-0.0383 \\
(0.0647)\end{array}$ & $\begin{array}{l}-0.0046 \\
(0.8965)\end{array}$ & $\begin{array}{l}-0.0429 \\
(0.5104)\end{array}$ & $\begin{array}{c}0.0230 \\
(0.1494)\end{array}$ \\
\hline Others & $\begin{array}{c}0.0274 * * * \\
(0.0087)\end{array}$ & $\begin{array}{l}-0.0062 \\
(0.0083)\end{array}$ & $\begin{array}{c}-0.0407 * * * \\
(0.0128)\end{array}$ & $\begin{array}{l}0.0212^{* *} \\
(0.0230)\end{array}$ & $\begin{array}{l}-0.0195 \\
(0.1060)\end{array}$ & $\begin{array}{c}0.0028 \\
(0.5733)\end{array}$ \\
\hline
\end{tabular}

M. Poor are lazy (N. of obs.: $86,305=; \mathrm{R}^{2}: 0.234$ )

\begin{tabular}{|c|c|c|c|c|c|c|}
\hline & $\begin{array}{l}\text { Raised } \\
\text { religiously }\end{array}$ & $\begin{array}{l}\text { Currently } \\
\text { religious }\end{array}$ & $\begin{array}{l}\text { Actively } \\
\text { religious }\end{array}$ & $\begin{aligned} & \text { Raised religiously } \\
+ & \text { Currently Religious }\end{aligned}$ & $\begin{array}{c}\text { Raised religiously } \\
\text { +Currently Religious+ } \\
\text { Actively Religious }\end{array}$ & $\begin{array}{c}\text { Total weighted impact } \\
\text { of religion }\end{array}$ \\
\hline \multirow[t]{2}{*}{ Catholic } & $-0.0059 *$ & $0.0120 * * *$ & 0.0039 & $0.0061^{*}$ & $0.0100^{* * * *}$ & $0.0064^{* * *}$ \\
\hline & $(0.0033)$ & $(0.0033)$ & $(0.0033)$ & $(0.0925)$ & $(0.0078)$ & $(0.0074)$ \\
\hline \multirow[t]{2}{*}{ Protestant } & $0.0106^{* *}$ & 0.0019 & $0.0104 *$ & $0.0125^{* * *}$ & $0.0229^{* * *}$ & $0.0088^{* * *}$ \\
\hline & $(0.0047)$ & $(0.0043)$ & $(0.0063)$ & $(0.0168)$ & $(0.0002)^{* *}$ & $(0.0004)$ \\
\hline \multirow[t]{2}{*}{ Jew } & 0.0323 & -0.0288 & 0.0350 & 0.0035 & 0.0385 & 0.0037 \\
\hline & $(0.0344)$ & $(0.0273)$ & $(0.0438)$ & $(0.9147)$ & $(0.3596)$ & $(0.7903)$ \\
\hline \multirow[t]{2}{*}{ Muslim } & $0.0487 * * *$ & 0.0080 & -0.0012 & $0.0567^{* * *}$ & $0.0555^{* * *}$ & $0.0381^{* * *}$ \\
\hline & $(0.0086)$ & $(0.0096)$ & $(0.0101)$ & $(0.0000)$ & $(0.0000)$ & $(0.0000)$ \\
\hline \multirow[t]{2}{*}{ Hindu } & $0.0657 * * *$ & -0.0051 & $-0.0214 * *$ & $0.0606^{* * *}$ & $0.0392^{* * *}$ & $0.0412^{* * *}$ \\
\hline & $(0.0129)$ & $(0.0126)$ & $(0.0101)$ & $(0.0000)$ & $(0.0007)$ & $(0.0000)$ \\
\hline \multirow[t]{2}{*}{ Buddhist } & 0.0107 & -0.0125 & 0.0538 & -0.0018 & 0.0520 & -0.0026 \\
\hline & $(0.0214)$ & $(0.0139)$ & $(0.0394)$ & $(0.9308)$ & $(0.1927)$ & $(0.7816)$ \\
\hline \multirow[t]{2}{*}{ Others } & $0.0142 * * *$ & $-0.0206 * * *$ & $0.0357 * * *$ & -0.0064 & $0.0293^{* * *}$ & -0.0007 \\
\hline & $(0.0053)$ & $(0.0052)$ & $(0.0078)$ & $(0.2632)$ & $(0.0001)$ & $(0.8042)$ \\
\hline
\end{tabular}




\section{Table 5. Interacting religious denominations and dominant religion}

Each panel reports the coefficients of an OLS regression, whose dependent variable is indicated at the top of the panel. All the dependent variables are defined in the legend of Table 1. In columns 1-3 the sample is restricted to countries where the dominant religion is Catholic, in columns 4-6 to countries where the dominant religion is Protestant, columns 7-9 where the dominant religion is Muslim. All regressions include as control variable (coefficients not reported) the same demographic controls as in Table 2 (health, male, age, education, social class, income), an indicator variable equal to 1 if a person answer no to the question "Do you believe in God?", a country fixed effect, and surveyyear dummies. In addition these regressions include the following three indicators of religious intensity: "Raised religiously" equal to one if the respondent answered positively to the question "Were you brought up religiously at home?"; "Currently religious" equal to one if the respondent attend religious services (apart from weddings, funerals and christenings) at least once a year; "Actively religious" is equal to one if the respondent attend religious services (apart from weddings, funerals and christenings) at least once a week. We report the coefficient of these variables in a cumulative way. Thus, the first column reports the coefficient on the dummy "raised religiously", the second column the sum of the coefficients of the dummies "raised religiously" and "currently religious", the third column the sum of the coefficients of the dummies "raised religiously", "currently religious", and "actively religious". Below the coefficient in bracket we report the p-values for the F-test that the coefficient is equal to zero (second and third column). ${ }^{* * *}$ indicate the coefficient is different from zero at the 1 percent level, ${ }^{* *}$ at the 5 percent level, and $*$ at the 10 percent level.

\section{Panel A: General trust}

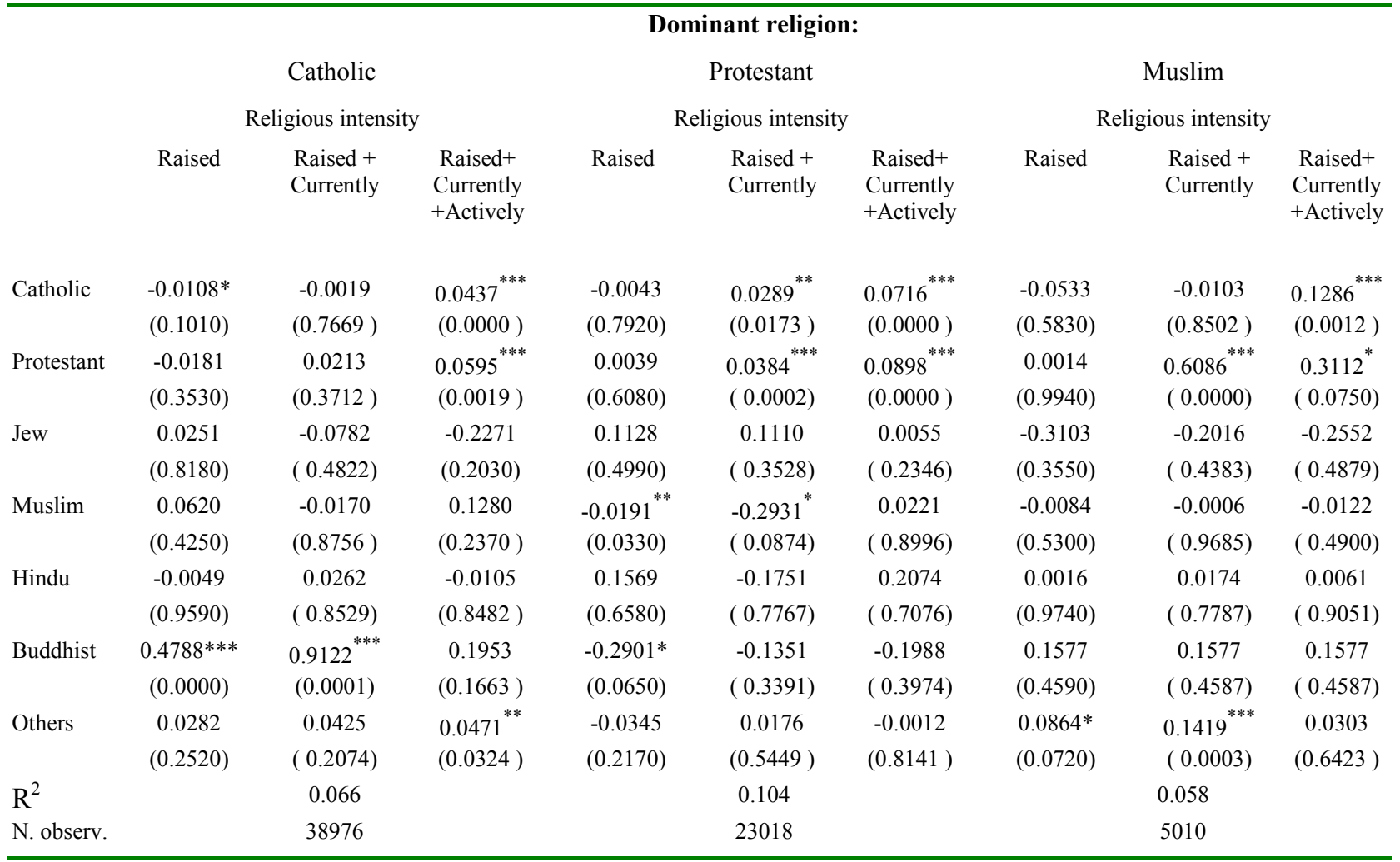


Panel B: Intolerance towards immigrants and other races

\begin{tabular}{|c|c|c|c|c|c|c|c|c|c|}
\hline & \multicolumn{9}{|c|}{ Dominant religion: } \\
\hline & \multicolumn{3}{|c|}{ Catholic } & \multicolumn{3}{|c|}{ Protestant } & \multicolumn{3}{|c|}{ Muslim } \\
\hline & \multicolumn{3}{|c|}{ Religious intensity } & \multicolumn{3}{|c|}{ Religious intensity } & \multicolumn{3}{|c|}{ Religious intensity } \\
\hline & Raised & $\begin{array}{l}\text { Raised + } \\
\text { Currently }\end{array}$ & $\begin{array}{l}\text { Raised+ } \\
\text { Currently } \\
\text { +Actively }\end{array}$ & Raised & $\begin{array}{l}\text { Raised }+ \\
\text { Currently }\end{array}$ & $\begin{array}{l}\text { Raised+ } \\
\text { Currently } \\
+ \text { Actively }\end{array}$ & Raised & $\begin{array}{l}\text { Raised + } \\
\text { Currently }\end{array}$ & $\begin{array}{l}\text { Raised+ } \\
\text { Currently } \\
\text { +Actively }\end{array}$ \\
\hline Catholic & $\begin{array}{c}0.0022 \\
(0.5770)\end{array}$ & $\begin{array}{l}0.0237^{* * *} \\
(0.0000)\end{array}$ & $\begin{array}{l}0.0271^{* * *} \\
(0.0000)\end{array}$ & $\begin{array}{c}-0.0144 * * \\
(0.0280)\end{array}$ & $\begin{array}{c}0.0008 \\
(0.9021)\end{array}$ & $\begin{array}{c}-0.0058 \\
(0.4057)\end{array}$ & $\begin{array}{l}-0.0876 \\
(0.1220)\end{array}$ & $\begin{array}{c}0.0100 \\
(0.7520)\end{array}$ & $\begin{array}{l}0.0613^{* * *} \\
(0.0084)\end{array}$ \\
\hline Protestant & $\begin{array}{l}-0.0043 \\
(0.7430)\end{array}$ & $\begin{array}{l}0.0304^{* *} \\
(0.0212)\end{array}$ & $\begin{array}{l}-0.0202 \\
(0.1015)\end{array}$ & $\begin{array}{c}0.0104 * * \\
(0.0210)\end{array}$ & $\begin{array}{l}0.0213^{* * *} \\
(0.0000)\end{array}$ & $\begin{array}{l}0.0337^{* * *} \\
(0.0000)\end{array}$ & $\begin{array}{l}-0.0337 \\
(0.7460)\end{array}$ & $\begin{array}{c}-0.0261 \\
(0.6420)\end{array}$ & $\begin{array}{c}0.0987 \\
(0.3326)\end{array}$ \\
\hline Jew & $\begin{array}{l}-0.0297 \\
(0.6430)\end{array}$ & $\begin{array}{c}-0.0008 \\
(0.9897)\end{array}$ & $\begin{array}{l}-0.2157^{* *} \\
(0.0435)\end{array}$ & $\begin{array}{c}0.0163 \\
(0.9490)\end{array}$ & $\begin{array}{c}0.0520 \\
(0.1449)\end{array}$ & $\begin{array}{c}0.0599 \\
(0.1296)\end{array}$ & $\begin{array}{l}-0.2081 \\
(0.2870)\end{array}$ & $\begin{array}{l}-0.2787^{*} \\
(0.0659)\end{array}$ & $\begin{array}{c}-0.1249 \\
(0.5601)\end{array}$ \\
\hline Muslim & $\begin{array}{l}-0.0195 \\
(0.6560)\end{array}$ & $\begin{array}{c}0.0545 \\
(0.3782)\end{array}$ & $\begin{array}{c}0.0143 \\
(0.8120)\end{array}$ & $\begin{array}{c}0.0421 \\
(0.3430)\end{array}$ & $\begin{array}{c}-0.0243 \\
(0.5887)\end{array}$ & $\begin{array}{c}0.0448 \\
(0.3789)\end{array}$ & $\begin{array}{l}-0.0012 \\
(0.8750)\end{array}$ & $\begin{array}{l}0.0581^{* * *} \\
(0.0000)\end{array}$ & $\begin{array}{l}0.0709^{* * *} \\
(0.0000)\end{array}$ \\
\hline Hindu & $\begin{array}{c}0.1177 * * \\
(0.0350)\end{array}$ & $\begin{array}{l}0.2636^{* * *} \\
(0.0008)\end{array}$ & $\begin{array}{c}0.0321 \\
(0.3121)\end{array}$ & $\begin{array}{c}0.0204 \\
(0.6790)\end{array}$ & $\begin{array}{c}0.0194 \\
(0.6861)\end{array}$ & $\begin{array}{c}0.0352 \\
(0.4771)\end{array}$ & $\begin{array}{c}0.0735^{* *} \\
(0.0140)\end{array}$ & $\begin{array}{c}0.0328 \\
(0.3647)\end{array}$ & $\begin{array}{c}0.0536^{*} \\
(0.0745)\end{array}$ \\
\hline Buddhist & $\begin{array}{c}0.0035 \\
(0.9630)\end{array}$ & $\begin{array}{c}0.0940 \\
(0.5398)\end{array}$ & $\begin{array}{c}0.0041 \\
(0.9594)\end{array}$ & $\begin{array}{l}0.1285^{*} \\
(0.0770)\end{array}$ & $\begin{array}{c}0.0572 \\
(0.3827)\end{array}$ & $\begin{array}{l}0.1855^{*} \\
(0.0906)\end{array}$ & $\begin{array}{l}-0.1179 \\
(0.3420)\end{array}$ & $\begin{array}{c}-0.1179 \\
(0.3415)\end{array}$ & $\begin{array}{c}-0.1179 \\
(0.3415)\end{array}$ \\
\hline Others & $\begin{array}{c}-0.0415^{* * * *} \\
(0.0060)\end{array}$ & $\begin{array}{l}-0.0504^{* *} \\
(0.0131)\end{array}$ & $\begin{array}{l}-0.0028 \\
(0.8289)\end{array}$ & $\begin{array}{c}0.0239 * * \\
(0.0420)\end{array}$ & $\begin{array}{l}-0.0032 \\
(0.8017)\end{array}$ & $\begin{array}{c}0.0015 \\
(0.9054)\end{array}$ & $\begin{array}{c}0.0109 \\
(0.7030)\end{array}$ & $\begin{array}{l}-0.0004 \\
(0.9861)\end{array}$ & $\begin{array}{l}-0.0105 \\
(0.7827)\end{array}$ \\
\hline $\mathrm{R}^{2}$ & & 0.168 & & & 0.167 & & & 0.124 & \\
\hline N. observ. & & 33324 & & & 25242 & & & 4901 & \\
\hline
\end{tabular}

Panel C: Trust in the government

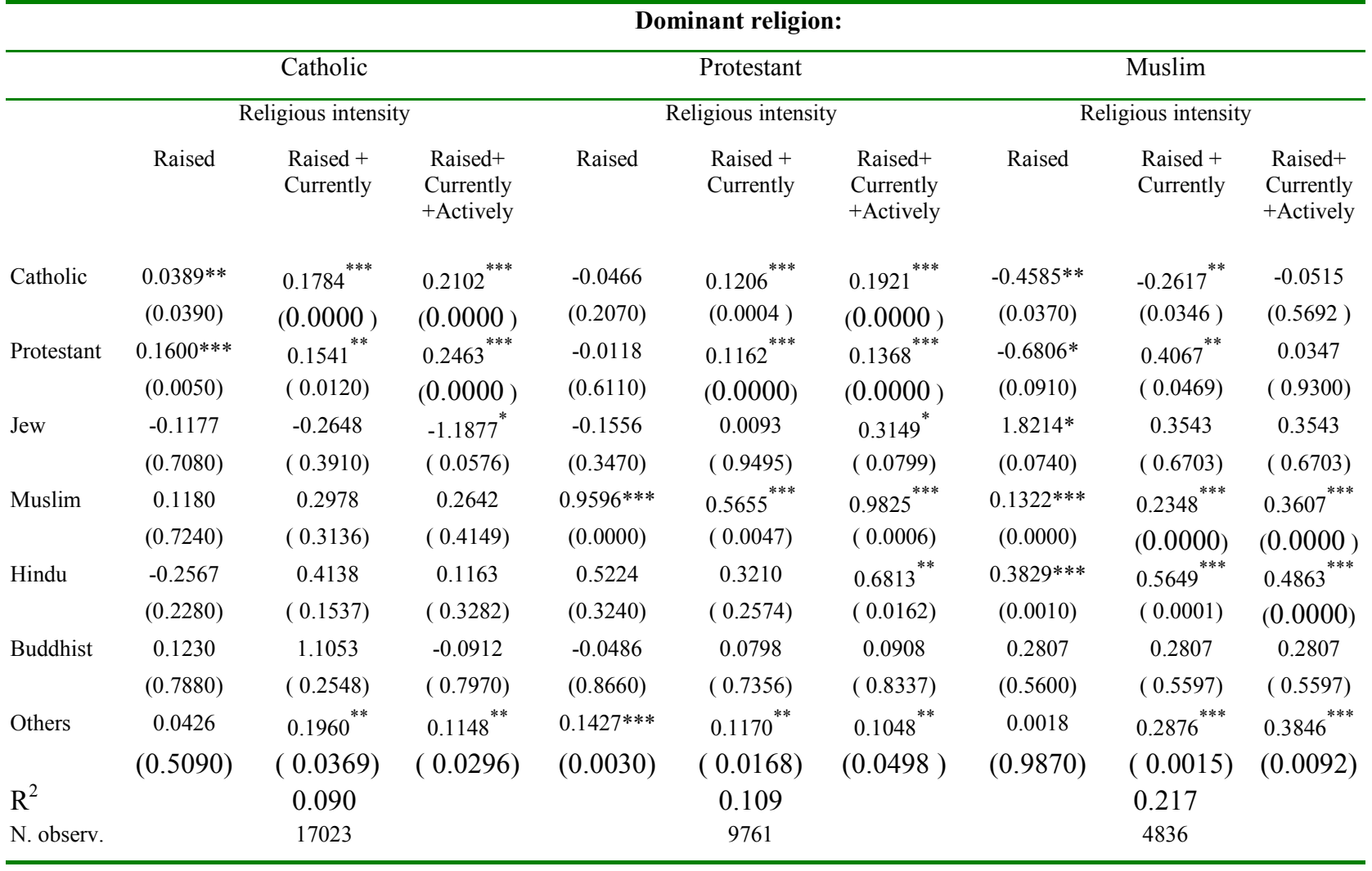


Panel D: Men deserve scarce jobs more than women

\begin{tabular}{|c|c|c|c|c|c|c|c|c|c|}
\hline & \multicolumn{9}{|c|}{ Dominant religion: } \\
\hline & \multicolumn{3}{|c|}{ Catholic } & \multicolumn{3}{|c|}{ Protestant } & \multicolumn{3}{|c|}{ Muslim } \\
\hline & \multicolumn{3}{|c|}{ Religious intensity } & \multicolumn{3}{|c|}{ Religious intensity } & \multicolumn{3}{|c|}{ Religious intensity } \\
\hline & Raised & $\begin{array}{l}\text { Raised + } \\
\text { Currently }\end{array}$ & $\begin{array}{l}\text { Raised+ } \\
\text { Currently } \\
\text { +Actively }\end{array}$ & Raised & $\begin{array}{l}\text { Raised + } \\
\text { Currently }\end{array}$ & $\begin{array}{l}\text { Raised+ } \\
\text { Currently } \\
\text { +Actively }\end{array}$ & Raised & $\begin{array}{l}\text { Raised + } \\
\text { Currently }\end{array}$ & $\begin{array}{l}\text { Raised+ } \\
\text { Currently } \\
\text { +Actively }\end{array}$ \\
\hline Catholic & $\begin{array}{c}0.0717 * * * \\
(0.0000)\end{array}$ & $\begin{array}{l}0.0707^{* * *} \\
(0.0000)\end{array}$ & $\begin{array}{l}0.1144^{* * *} \\
(0.0000)\end{array}$ & $\begin{array}{c}0.0129 \\
(0.6800)\end{array}$ & $\begin{array}{c}0.0091 \\
(0.7432)\end{array}$ & $\begin{array}{l}0.1363^{* * *} \\
(0.0000)\end{array}$ & $\begin{array}{c}0.1402 \\
(0.5480)\end{array}$ & $\begin{array}{c}0.0841 \\
(0.5053)\end{array}$ & $\begin{array}{c}0.0993 \\
(0.2846)\end{array}$ \\
\hline Protestant & $\begin{array}{c}0.0109 \\
(0.8080)\end{array}$ & $\begin{array}{c}0.0444 \\
(0.3411)\end{array}$ & $\begin{array}{l}0.1074^{* * *} \\
(0.0053)\end{array}$ & $\begin{array}{c}0.0925^{* * *} \\
(0.0000)\end{array}$ & $\begin{array}{l}0.0700^{* * *} \\
(0.0007)\end{array}$ & $\begin{array}{l}0.1591^{* * *} \\
(0.0000)\end{array}$ & $\begin{array}{c}0.9278 * * \\
(0.0250)\end{array}$ & $\begin{array}{c}0.3693^{*} \\
(0.0784)\end{array}$ & $\begin{array}{c}0.5903 \\
(0.1453)\end{array}$ \\
\hline Jew & $\begin{array}{c}0.0400 \\
(0.8660)\end{array}$ & $\begin{array}{l}-0.1563 \\
(0.5214)\end{array}$ & $\begin{array}{l}-0.2384 \\
(0.5779)\end{array}$ & $\begin{array}{l}-0.2028 \\
(0.2000)\end{array}$ & $\begin{array}{l}-0.2457^{*} \\
(0.0923)\end{array}$ & $\begin{array}{c}0.0823 \\
(0.6410)\end{array}$ & $\begin{array}{c}-2.1880 * * * \\
(0.0050)\end{array}$ & $\begin{array}{l}-1.1833^{* *} \\
(0.0498)\end{array}$ & $\begin{array}{c}-0.9660 \\
(0.2576)\end{array}$ \\
\hline Muslim & $\begin{array}{l}0.2934^{*} \\
(0.0850)\end{array}$ & $\begin{array}{c}0.2120 \\
(0.3621)\end{array}$ & $\begin{array}{c}0.1127 \\
(0.6327)\end{array}$ & $\begin{array}{c}0.1769 \\
(0.2700)\end{array}$ & $\begin{array}{l}0.6243^{* * *} \\
(0.0014)\end{array}$ & $\begin{array}{c}0.4648 \\
(0.0782)\end{array}$ & $\begin{array}{c}0.0489 \\
(0.1200)\end{array}$ & $\begin{array}{l}0.2101^{* * *} \\
(0.0000)\end{array}$ & $\begin{array}{l}0.3254^{* * *} \\
(0.0000)\end{array}$ \\
\hline Hindu & $\begin{array}{c}0.3029 \\
(0.1390)\end{array}$ & $\begin{array}{l}0.5637^{* *} \\
(0.0497)\end{array}$ & $\begin{array}{c}0.1987^{*} \\
(0.0871)\end{array}$ & $\begin{array}{c}0.6136 \\
(0.1220)\end{array}$ & $\begin{array}{l}0.6451^{* * *} \\
(0.0046)\end{array}$ & $\begin{array}{l}0.8059^{* * *} \\
(0.0038)\end{array}$ & $\begin{array}{l}0.2465^{* *} \\
(0.0400)\end{array}$ & $\begin{array}{c}0.1543 \\
(0.2840)\end{array}$ & $\begin{array}{c}0.1294 \\
(0.2822)\end{array}$ \\
\hline Buddhist & $\begin{array}{l}-0.1543 \\
(0.5260)\end{array}$ & $\begin{array}{c}0.5227 \\
(0.3113)\end{array}$ & $\begin{array}{l}-0.3613 \\
(0.2205)\end{array}$ & $\begin{array}{l}0.4601^{*} \\
(0.0770)\end{array}$ & $\begin{array}{c}0.1964 \\
(0.4274)\end{array}$ & $\begin{array}{c}0.3833 \\
(0.3991)\end{array}$ & $\begin{array}{l}0.8516^{*} \\
(0.0840)\end{array}$ & $\begin{array}{c}0.8516^{*} \\
(0.0844)\end{array}$ & $\begin{array}{c}0.8516^{*} \\
(0.0844)\end{array}$ \\
\hline Others & $\begin{array}{l}-0.0340 \\
(0.5120)\end{array}$ & $\begin{array}{l}-0.0448 \\
(0.5329)\end{array}$ & $\begin{array}{l}0.1372^{* * *} \\
(0.0026)\end{array}$ & $\begin{array}{l}0.0799 * \\
(0.9140)\end{array}$ & $\begin{array}{c}0.0219 \\
(0.6392)\end{array}$ & $\begin{array}{l}0.1956^{* * *} \\
(0.0001)\end{array}$ & $\begin{array}{l}-0.0839 \\
(0.4520)\end{array}$ & $\begin{array}{c}-0.1493 \\
(0.1021)\end{array}$ & $\begin{array}{c}-0.0569 \\
(0.7067)\end{array}$ \\
\hline $\mathrm{R}^{2}$ & & 0.101 & & & 0.132 & & & 0.098 & \\
\hline N. observ. & & 31750 & & & 16658 & & & 4934 & \\
\hline
\end{tabular}

\section{Panel E: Men deserve university education more than women}

\begin{tabular}{|c|c|c|c|c|c|c|c|c|c|}
\hline & \multicolumn{9}{|c|}{ Dominant religion: } \\
\hline & \multicolumn{3}{|c|}{ Catholic } & \multicolumn{3}{|c|}{ Protestant } & \multicolumn{3}{|c|}{ Muslim } \\
\hline & \multicolumn{3}{|c|}{ Religious intensity } & \multicolumn{3}{|c|}{ Religious intensity } & \multicolumn{3}{|c|}{ Religious intensity } \\
\hline & Raised & $\begin{array}{l}\text { Raised + } \\
\text { Currently }\end{array}$ & $\begin{array}{l}\text { Raised+ } \\
\text { Currently } \\
\text { +Actively }\end{array}$ & Raised & $\begin{array}{l}\text { Raised + } \\
\text { Currently }\end{array}$ & $\begin{array}{l}\text { Raised+ } \\
\text { Currently } \\
\text { +Actively }\end{array}$ & Raised & $\begin{array}{l}\text { Raised + } \\
\text { Currently }\end{array}$ & $\begin{array}{l}\text { Raised+ } \\
\text { Currently } \\
\text { +Actively }\end{array}$ \\
\hline \multirow[t]{2}{*}{ Catholic } & 0.0258 & 0.0293 & $0.0653^{* * *}$ & 0.0047 & 0.0329 & $0.1077^{* *}$ & -0.4091 & $0.4985^{* * *}$ & 0.0921 \\
\hline & $(0.1720)$ & $(0.1587)$ & $(0.0022)$ & $(0.9130)$ & $(0.3943)$ & $(0.0175)$ & $(0.1190)$ & $(0.0005)$ & $(0.3775)$ \\
\hline \multirow[t]{2}{*}{ Protestant } & 0.0687 & $0.2262^{* * *}$ & $0.1089^{* *}$ & -0.0056 & 0.0069 & $0.0838^{* *}$ & -0.0393 & 0.2457 & 0.3805 \\
\hline & $(0.3200)$ & $(0.0054)$ & $(0.0293)$ & $(0.8230)$ & $(0.8120)$ & $(0.0392)$ & $(0.9320)$ & $(0.2976)$ & $(0.4036)$ \\
\hline Jew & 0.1716 & -0.0497 & 0.0680 & -0.0877 & -0.0338 & $-0.3846^{*}$ & -0.5207 & 0.3914 & -0.8165 \\
\hline \multirow[t]{2}{*}{ Muslim } & $0.6165 * *$ & -0.5001 & 0.2924 & -0.0532 & -0.0256 & -0.0099 & -0.0427 & -0.0024 & $0.2406^{* * *}$ \\
\hline & $(0.0320)$ & $(0.1043)$ & $(0.4039)$ & $(0.8350)$ & $(0.8930)$ & $(0.9739)$ & $(0.2280)$ & $(0.9580)$ & $(0.0000)$ \\
\hline \multirow[t]{2}{*}{ Hindu } & 0.0377 & 0.1848 & 0.1122 & -0.2364 & $0.6932^{* *}$ & $1.1430^{* * *}$ & 0.0965 & 0.0850 & $0.2386^{*}$ \\
\hline & $(0.8540)$ & $(0.5073)$ & $(0.3189)$ & $(0.6480)$ & $(0.0126)$ & $(0.0071)$ & $(0.5080)$ & $(0.6045)$ & $(0.0786)$ \\
\hline \multirow[t]{2}{*}{ Buddhist } & $1.2845 * *$ & 0.4402 & 0.4402 & -0.3597 & -0.1570 & -0.8293 & $0.9684 *$ & $0.9684^{*}$ & $0.9684^{*}$ \\
\hline & $(0.0200)$ & $(0.2608)$ & $(0.2608)$ & $(0.2210)$ & $(0.5224)$ & $(0.2580)$ & $(0.0810)$ & $(0.0809)$ & ( 0.0809$)$ \\
\hline \multirow[t]{2}{*}{ Others } & 0.0109 & -0.0132 & -0.0636 & 0.0210 & $0.1323^{* *}$ & $0.1310^{* *}$ & 0.1594 & $0.5211^{* * *}$ & $0.7546^{* * *}$ \\
\hline & $(0.8720)$ & $(0.8863)$ & $(0.2234)$ & $(0.7080)$ & $(0.0130)$ & $(0.0325)$ & $(0.2090)$ & $(0.0000)$ & $(0.0000)$ \\
\hline $\mathrm{R}^{2}$ & & 0.078 & & & 0.180 & & & 0.092 & \\
\hline N. observ. & & 15126 & & & 7885 & & & 4880 & \\
\hline
\end{tabular}


Panel F: Trust in the legal system

\begin{tabular}{|c|c|c|c|c|c|c|c|c|c|}
\hline & \multicolumn{9}{|c|}{ Dominant religion: } \\
\hline & \multicolumn{3}{|c|}{ Catholic } & \multicolumn{3}{|c|}{ Protestant } & \multicolumn{3}{|c|}{ Muslim } \\
\hline & \multicolumn{3}{|c|}{ Religious intensity } & \multicolumn{3}{|c|}{ Religious intensity } & \multicolumn{3}{|c|}{ Religious intensity } \\
\hline & Raised & $\begin{array}{l}\text { Raised }+ \\
\text { Currently }\end{array}$ & $\begin{array}{l}\text { Raised+ } \\
\text { Currently } \\
+ \text { Actively }\end{array}$ & Raised & $\begin{array}{l}\text { Raised + } \\
\text { Currently }\end{array}$ & $\begin{array}{l}\text { Raised+ } \\
\text { Currently } \\
+ \text { Actively }\end{array}$ & Raised & $\begin{array}{l}\text { Raised + } \\
\text { Currently }\end{array}$ & $\begin{array}{l}\text { Raised+ } \\
\text { Currently } \\
+ \text { Actively }\end{array}$ \\
\hline Catholic & $\begin{array}{c}0.0396 * * * \\
(0.0030)\end{array}$ & $\begin{array}{l}0.1573^{* * *} \\
(0.0000)\end{array}$ & $\begin{array}{l}0.2427^{* * *} \\
(0.0000)\end{array}$ & $\begin{array}{c}0.0314 \\
(0.1710)\end{array}$ & $\begin{array}{l}0.1112^{* * *} \\
(0.0000)\end{array}$ & $\begin{array}{l}0.1416^{* * *} \\
(0.0000)\end{array}$ & $\begin{array}{l}-0.3785^{*} \\
(0.0910)\end{array}$ & $\begin{array}{l}-0.4973^{* * *} \\
(0.0000)\end{array}$ & $\begin{array}{l}-0.1871^{* *} \\
(0.0368)\end{array}$ \\
\hline Protestant & $\begin{array}{l}0.0784 * \\
(0.0640)\end{array}$ & $\begin{array}{l}0.1787^{* * *} \\
(0.0001)\end{array}$ & $\begin{array}{l}0.2556^{* * *} \\
(0.0000)\end{array}$ & $\begin{array}{c}0.0458^{* * *} \\
(0.0040)\end{array}$ & $\begin{array}{l}0.1327^{* * *} \\
(0.0000)\end{array}$ & $\begin{array}{l}0.1827^{* * *} \\
(0.0000)\end{array}$ & $\begin{array}{l}-0.2884 \\
(0.4680)\end{array}$ & $\begin{array}{l}0.4416^{* *} \\
(0.0338)\end{array}$ & $\begin{array}{l}-0.1577 \\
(0.6861)\end{array}$ \\
\hline Jew & $\begin{array}{l}-0.0546 \\
(0.8080)\end{array}$ & $\begin{array}{c}-0.0183 \\
(0.9358)\end{array}$ & $\begin{array}{c}-0.0257 \\
(0.9438)\end{array}$ & $\begin{array}{c}0.1244 \\
(0.3210)\end{array}$ & $\begin{array}{l}0.2108^{*} \\
(0.0906)\end{array}$ & $\begin{array}{c}0.2918 \\
(0.346)\end{array}$ & $\begin{array}{c}0.2926 \\
(0.7710)\end{array}$ & $\begin{array}{l}-1.3066 \\
(0.1115)\end{array}$ & $\begin{array}{l}-0.7308 \\
(0.3736)\end{array}$ \\
\hline Muslim & $\begin{array}{c}0.5413^{* * *} \\
(0.0010)\end{array}$ & $\begin{array}{c}0.3470 \\
(0.1516)\end{array}$ & $\begin{array}{c}0.4073^{*} \\
(0.0658)\end{array}$ & $\begin{array}{c}0.5366^{* * *} \\
(0.0010)\end{array}$ & $\begin{array}{c}0.1370 \\
(0.3804)\end{array}$ & $\begin{array}{l}0.5076^{* * *} \\
(0.0042)\end{array}$ & $\begin{array}{c}0.1090^{* * *} \\
(0.0000)\end{array}$ & $\begin{array}{l}0.1568^{* * *} \\
(0.0001)\end{array}$ & $\begin{array}{l}0.2332^{* * *} \\
(0.0000)\end{array}$ \\
\hline Hindu & $\begin{array}{l}-0.0201 \\
(0.9220)\end{array}$ & $\begin{array}{c}-0.4270 \\
(0.1385)\end{array}$ & $\begin{array}{c}0.0627 \\
(0.5939)\end{array}$ & $\begin{array}{c}0.2360 \\
(0.1780)\end{array}$ & $\begin{array}{c}0.2047 \\
(0.2337)\end{array}$ & $\begin{array}{c}0.2666 \\
(0.1291)\end{array}$ & $\begin{array}{l}0.2095^{*} \\
(0.0670)\end{array}$ & $\begin{array}{c}0.1418 \\
(0.3067)\end{array}$ & $\begin{array}{c}0.0869 \\
(0.4506)\end{array}$ \\
\hline Buddhist & $\begin{array}{c}0.0681 \\
(0.7780)\end{array}$ & $\begin{array}{c}0.1867 \\
(0.6868)\end{array}$ & $\begin{array}{c}0.4477 \\
(0.1211)\end{array}$ & $\begin{array}{l}0.6011 * * \\
(0.0200)\end{array}$ & $\begin{array}{c}0.4516^{*} \\
(0.0588)\end{array}$ & $\begin{array}{c}-0.0334 \\
(0.9305)\end{array}$ & $\begin{array}{c}0.1705 \\
(0.7200)\end{array}$ & $\begin{array}{c}0.1705 \\
(0.7196)\end{array}$ & $\begin{array}{c}0.1705 \\
(0.7196)\end{array}$ \\
\hline Others & $\begin{array}{l}-0.0534 \\
(0.2930)\end{array}$ & $\begin{array}{c}-0.0244 \\
(0.7281)\end{array}$ & $\begin{array}{c}0.0812^{*} \\
(0.0753)\end{array}$ & $\begin{array}{l}-0.0188 \\
(0.6490)\end{array}$ & $\begin{array}{c}0.0810^{*} \\
(0.0630)\end{array}$ & $\begin{array}{l}0.1883^{* * *} \\
(0.0000)\end{array}$ & $\begin{array}{c}-0.2302 * * \\
(0.0330)\end{array}$ & $\begin{array}{c}-0.0111 \\
(0.9007)\end{array}$ & $\begin{array}{c}-0.0745 \\
(0.6091)\end{array}$ \\
\hline $\mathrm{R}^{2}$ & & 0.057 & & & 0.108 & & & 0.103 & \\
\hline N. observ. & & 38368 & & & 22779 & & & 4870 & \\
\hline
\end{tabular}

Panel G: Is it justified to cheat on taxes?

Dominant religion:

\begin{tabular}{|c|c|c|c|c|c|c|c|c|c|}
\hline & \multicolumn{3}{|c|}{ Catholic } & \multicolumn{3}{|c|}{ Protestant } & \multicolumn{3}{|c|}{ Muslim } \\
\hline & \multicolumn{3}{|c|}{ Religious intensity } & \multicolumn{3}{|c|}{ Religious intensity } & \multicolumn{3}{|c|}{ Religious intensity } \\
\hline & Raised & $\begin{array}{l}\text { Raised + } \\
\text { Currently }\end{array}$ & $\begin{array}{l}\text { Raised+ } \\
\text { Currently } \\
\text { +Actively }\end{array}$ & Raised & $\begin{array}{l}\text { Raised + } \\
\text { Currently }\end{array}$ & $\begin{array}{l}\text { Raised+ } \\
\text { Currently } \\
\text { +Actively }\end{array}$ & Raised & $\begin{array}{l}\text { Raised + } \\
\text { Currently }\end{array}$ & $\begin{array}{l}\text { Raised+ } \\
\text { Currently } \\
\text { +Actively }\end{array}$ \\
\hline Catholic & $\begin{array}{c}-0.1584 * * * \\
(0.0000)\end{array}$ & $\begin{array}{l}-0.1942^{* * *} \\
(0.0000)\end{array}$ & $\begin{array}{l}-0.4017^{* * *} \\
(0.0000)\end{array}$ & $\begin{array}{l}-0.0957 \\
(0.1610)\end{array}$ & $\begin{array}{l}-0.2945^{* * *} \\
(0.0000)\end{array}$ & $\begin{array}{l}-0.5684^{* * *} \\
(0.0000)\end{array}$ & $\begin{array}{c}0.3979 \\
(0.5390)\end{array}$ & $\begin{array}{l}1.0316^{* * *} \\
(0.0025)\end{array}$ & $\begin{array}{c}0.3657 \\
(0.1493)\end{array}$ \\
\hline Protestant & $\begin{array}{c}-0.4182 * * * \\
(0.0000)\end{array}$ & $\begin{array}{c}-0.3775^{* * *} \\
(0.0032)\end{array}$ & $\begin{array}{l}-0.6874^{* * *} \\
(0.0000)\end{array}$ & $\begin{array}{c}-0.1608^{* * *} \\
(0.0010)\end{array}$ & $\begin{array}{l}-0.4751^{* * *} \\
(0.0000)\end{array}$ & $\begin{array}{l}-0.9851^{* * *} \\
(0.0000)\end{array}$ & $\begin{array}{l}-0.0270 \\
(0.9810)\end{array}$ & $\begin{array}{c}0.5164 \\
(0.3592)\end{array}$ & $\begin{array}{c}1.1428 \\
(0.3535)\end{array}$ \\
\hline Jew & $\begin{array}{l}-1.1388^{*} \\
(0.0740)\end{array}$ & $\begin{array}{c}-0.5202 \\
(0.4207)\end{array}$ & $\begin{array}{c}-1.5856 \\
(0.1266)\end{array}$ & $\begin{array}{l}-0.0816 \\
(0.8260)\end{array}$ & $\begin{array}{c}0.0426 \\
(0.9083)\end{array}$ & $\begin{array}{c}-1.4567^{* * *} \\
(0.0004)\end{array}$ & $\begin{array}{c}0.3057 \\
(0.8830)\end{array}$ & $\begin{array}{c}-1.5506 \\
(0.3362)\end{array}$ & $\begin{array}{c}2.0666 \\
(0.3648)\end{array}$ \\
\hline Muslim & $\begin{array}{l}-0.0796 \\
(0.8600)\end{array}$ & $\begin{array}{c}-1.0572 \\
(0.1008)\end{array}$ & $\begin{array}{c}-0.3294 \\
(0.6004)\end{array}$ & $\begin{array}{l}-0.0887 \\
(0.8480)\end{array}$ & $\begin{array}{c}-0.3321 \\
(0.4767)\end{array}$ & $\begin{array}{c}-0.6415 \\
(0.2300)\end{array}$ & $\begin{array}{l}-0.1702 \\
(0.1130)\end{array}$ & $\begin{array}{c}0.0191 \\
(0.8801)\end{array}$ & $\begin{array}{c}0.0081 \\
(0.9538)\end{array}$ \\
\hline Hindu & $\begin{array}{c}0.6037 \\
(0.3010)\end{array}$ & $\begin{array}{c}0.7268 \\
(0.3748)\end{array}$ & $\begin{array}{l}-0.6391^{*} \\
(0.0537)\end{array}$ & $\begin{array}{l}-0.5929 \\
(0.2470)\end{array}$ & $\begin{array}{c}-1.6180^{* * *} \\
(0.0012)\end{array}$ & $\begin{array}{c}-1.3761^{* * *} \\
(0.0076)\end{array}$ & $\begin{array}{l}-0.1980 \\
(0.5390)\end{array}$ & $\begin{array}{c}-0.0330 \\
(0.9327)\end{array}$ & $\begin{array}{c}-0.1212 \\
(0.7140)\end{array}$ \\
\hline Buddhist & $\begin{array}{l}-0.2321 \\
(0.7350)\end{array}$ & $\begin{array}{c}-1.3573 \\
(0.3020)\end{array}$ & $\begin{array}{c}-0.9988 \\
(0.2236)\end{array}$ & $\begin{array}{l}-0.4868 \\
(0.5180)\end{array}$ & $\begin{array}{c}-0.2457 \\
(0.7172)\end{array}$ & $\begin{array}{c}-0.3671 \\
(0.7464)\end{array}$ & $\begin{array}{l}-0.3387 \\
(0.7980)\end{array}$ & $\begin{array}{c}-0.3387 \\
(0.7976)\end{array}$ & $\begin{array}{c}-0.3387 \\
(0.7976)\end{array}$ \\
\hline Others & $\begin{array}{c}0.0119 \\
(0.9340)\end{array}$ & $\begin{array}{c}-0.2171 \\
(0.2767)\end{array}$ & $\begin{array}{l}-0.6833^{* * *} \\
(0.0000)\end{array}$ & $\begin{array}{l}-0.1547 \\
(0.2070)\end{array}$ & $\begin{array}{c}0.0577 \\
(0.6570)\end{array}$ & $\begin{array}{l}-0.9370^{* * *} \\
(0.0000)\end{array}$ & $\begin{array}{c}0.2266 \\
(0.4780)\end{array}$ & $\begin{array}{l}0.6301^{* *} \\
(0.0115)\end{array}$ & $\begin{array}{c}0.6445 \\
(0.1151)\end{array}$ \\
\hline $\begin{array}{l}\mathrm{R}^{2} \\
\text { N. observ. }\end{array}$ & & $\begin{array}{l}0.085 \\
38041\end{array}$ & & & $\begin{array}{c}0.098 \\
25078\end{array}$ & & & $\begin{array}{l}0.187 \\
3638\end{array}$ & \\
\hline
\end{tabular}


Panel H: Is it justified to accept a bribe?

\begin{tabular}{|c|c|c|c|c|c|c|c|c|c|}
\hline & \multicolumn{9}{|c|}{ Dominant religion: } \\
\hline & \multicolumn{3}{|c|}{ Catholic } & \multicolumn{3}{|c|}{ Protestant } & \multicolumn{3}{|c|}{ Muslim } \\
\hline & \multicolumn{3}{|c|}{ Religious intensity } & \multicolumn{3}{|c|}{ Religious intensity } & \multicolumn{3}{|c|}{ Religious intensity } \\
\hline & Raised & $\begin{array}{l}\text { Raised + } \\
\text { Currently }\end{array}$ & $\begin{array}{l}\text { Raised+ } \\
\text { Currently } \\
\text { +Actively }\end{array}$ & Raised & $\begin{array}{l}\text { Raised + } \\
\text { Currently }\end{array}$ & $\begin{array}{l}\text { Raised+ } \\
\text { Currently } \\
\text { +Actively }\end{array}$ & Raised & $\begin{array}{l}\text { Raised + } \\
\text { Currently }\end{array}$ & $\begin{array}{l}\text { Raised+ } \\
\text { Currently } \\
+ \text { Actively }\end{array}$ \\
\hline Catholic & $\begin{array}{l}-0.0497 * \\
(0.0610)\end{array}$ & $\begin{array}{c}-0.0301 \\
(0.3094)\end{array}$ & $\begin{array}{c}-0.0875^{* * *} \\
(0.0039)\end{array}$ & $\begin{array}{c}-0.0833 * * \\
(0.0440)\end{array}$ & $\begin{array}{c}-0.0244 \\
(0.5676)\end{array}$ & $\begin{array}{l}-0.2263^{* * *} \\
(0.0000)\end{array}$ & $\begin{array}{l}-0.1291 \\
(0.7860)\end{array}$ & $\begin{array}{c}0.0289 \\
(0.9109)\end{array}$ & $\begin{array}{c}0.1134 \\
(0.5552)\end{array}$ \\
\hline Protestant & $\begin{array}{l}-0.0990 \\
(0.2350)\end{array}$ & $\begin{array}{c}-0.1406 \\
(0.1137)\end{array}$ & $\begin{array}{l}-0.1717^{* *} \\
(0.0218)\end{array}$ & $\begin{array}{l}-0.0095 \\
(07370 .)\end{array}$ & $\begin{array}{l}-0.0727^{* *} \\
(0.0238)\end{array}$ & $\begin{array}{l}-0.2842^{* * *} \\
(0.0000)\end{array}$ & $\begin{array}{c}0.6284 \\
(0.4700)\end{array}$ & $\begin{array}{c}0.0713 \\
(0.8677)\end{array}$ & $\begin{array}{c}0.6320 \\
(0.5001)\end{array}$ \\
\hline Jew & $\begin{array}{l}-0.2778 \\
(0.5300)\end{array}$ & $\begin{array}{c}0.8085^{*} \\
(0.0716)\end{array}$ & $\begin{array}{l}-0.1224 \\
(0.8652)\end{array}$ & $\begin{array}{c}0.2170 \\
(0.3410)\end{array}$ & $\begin{array}{c}0.1035 \\
(0.6462)\end{array}$ & $\begin{array}{l}-0.0897 \\
(0.7243)\end{array}$ & $\begin{array}{l}-0.1808 \\
(0.9170)\end{array}$ & $\begin{array}{l}-1.1195 \\
(0.3617)\end{array}$ & $\begin{array}{c}-0.7599 \\
(0.6615)\end{array}$ \\
\hline Muslim & $\begin{array}{l}0.5425 * \\
(0.0910)\end{array}$ & $\begin{array}{c}-0.0911 \\
(0.8429)\end{array}$ & $\begin{array}{c}-0.3925 \\
(0.3856)\end{array}$ & $\begin{array}{l}-0.4244 \\
(0.1300)\end{array}$ & $\begin{array}{c}0.2388 \\
(0.3975)\end{array}$ & $\begin{array}{c}-0.3307 \\
(0.3099)\end{array}$ & $\begin{array}{c}0.5578 * * * \\
(0.0000)\end{array}$ & $\begin{array}{c}-0.3286^{* * *} \\
(0.0007)\end{array}$ & $\begin{array}{l}0.3735^{* * *} \\
(0.0004)\end{array}$ \\
\hline Hindu & $\begin{array}{c}0.4590 \\
(0.2570)\end{array}$ & $\begin{array}{c}-0.6577 \\
(0.2476)\end{array}$ & $\begin{array}{c}0.0120 \\
(0.9581)\end{array}$ & $\begin{array}{c}0.0159 \\
(0.9590)\end{array}$ & $\begin{array}{l}-0.1671 \\
(0.5805)\end{array}$ & $\begin{array}{l}-0.1098 \\
(0.7252)\end{array}$ & $\begin{array}{l}-0.3296 \\
(0.1790)\end{array}$ & $\begin{array}{l}-0.2657 \\
(0.3774)\end{array}$ & $\begin{array}{l}-0.4389^{*} \\
(0.0810)\end{array}$ \\
\hline Buddhist & $\begin{array}{c}0.1576 \\
(0.7410)\end{array}$ & $\begin{array}{c}-0.8962 \\
(0.3265)\end{array}$ & $\begin{array}{c}-0.4262 \\
(0.4545)\end{array}$ & $\begin{array}{l}-0.0874 \\
(0.8480)\end{array}$ & $\begin{array}{c}0.3964 \\
(0.3351)\end{array}$ & $\begin{array}{c}0.1470 \\
(0.8310)\end{array}$ & $\begin{array}{l}-0.4185 \\
(0.6770)\end{array}$ & $\begin{array}{c}-0.4185 \\
(0.6771)\end{array}$ & $\begin{array}{c}-0.4185 \\
(0.6771)\end{array}$ \\
\hline Others & $\begin{array}{c}0.1546 \\
(0.1200)\end{array}$ & $\begin{array}{c}-0.1458 \\
(0.2881)\end{array}$ & $\begin{array}{l}-0.1483^{*} \\
(0.0949)\end{array}$ & $\begin{array}{l}-0.0633 \\
(0.3910)\end{array}$ & $\begin{array}{c}0.0491 \\
(0.5293)\end{array}$ & $\begin{array}{l}-0.2427^{* * *} \\
(0.0035)\end{array}$ & $\begin{array}{c}0.0690 \\
(0.7770)\end{array}$ & $\begin{array}{l}-0.1606 \\
(0.3974)\end{array}$ & $\begin{array}{c}-0.1654 \\
(0.5952)\end{array}$ \\
\hline $\mathrm{R}^{2}$ & & 0.071 & & & 0.062 & & & 0.182 & \\
\hline N. observ. & & 37997 & & & 25097 & & & 3676 & \\
\hline
\end{tabular}

Panel I: Accept more income inequality to provide incentives?

Dominant religion:

\begin{tabular}{|c|c|c|c|c|c|c|c|c|c|}
\hline & \multicolumn{3}{|c|}{ Catholic } & \multicolumn{3}{|c|}{ Protestant } & \multicolumn{3}{|c|}{ Muslim } \\
\hline & \multicolumn{3}{|c|}{ Religious intensity } & \multicolumn{3}{|c|}{ Religious intensity } & \multicolumn{3}{|c|}{ Religious intensity } \\
\hline & Raised & $\begin{array}{l}\text { Raised + } \\
\text { Currently }\end{array}$ & $\begin{array}{l}\text { Raised+ } \\
\text { Currently } \\
+ \text { Actively }\end{array}$ & Raised & $\begin{array}{l}\text { Raised + } \\
\text { Currently }\end{array}$ & $\begin{array}{l}\text { Raised+ } \\
\text { Currently } \\
+ \text { Actively }\end{array}$ & Raised & $\begin{array}{l}\text { Raised + } \\
\text { Currently }\end{array}$ & $\begin{array}{l}\text { Raised+ } \\
\text { Currently } \\
+ \text { Actively }\end{array}$ \\
\hline \multirow[t]{2}{*}{ Catholic } & 0.0430 & -0.0215 & -0.0592 & $-0.1625^{*}$ & -0.0175 & -0.0830 & -0.0463 & 0.2804 & -0.0713 \\
\hline & $(0.3850)$ & $(0.6954)$ & $(0.3006)$ & $(0.1000)$ & $(0.8415)$ & $(0.3594)$ & $(0.9540)$ & $(0.5271)$ & $(0.8267)$ \\
\hline \multirow[t]{2}{*}{ Protestant } & -0.1694 & -0.1080 & 0.1502 & 0.0685 & 0.0768 & $0.1966^{* *}$ & -0.5815 & $-1.5222^{* *}$ & -0.8288 \\
\hline & $(0.2930)$ & $(0.5083)$ & $(0.3001)$ & $(0.2200)$ & $(0.2354)$ & $(0.0288)$ & $(0.6890)$ & $(0.0397)$ & $(0.5620)$ \\
\hline \multirow[t]{2}{*}{ Jew } & -0.1534 & 0.3268 & -0.9852 & -0.1545 & 0.0817 & $-1.1616^{* *}$ & -2.7138 & -0.5617 & -2.4224 \\
\hline & $(0.8540)$ & $(0.9853)$ & $(0.5004)$ & $(0.7710)$ & $(0.8597)$ & $(0.0439)$ & $(0.3220)$ & $(0.7918)$ & $(0.4208)$ \\
\hline \multirow[t]{2}{*}{ Muslim } & -0.1035 & -0.4495 & 0.4705 & -1.0102 & 0.3998 & 0.1319 & $-0.4514 * * *$ & $-0.5294^{* * *}$ & $-0.2666^{*}$ \\
\hline & $(0.8560)$ & $(0.5707)$ & $(0.5585)$ & $(0.1520)$ & $(0.5152)$ & $(0.8737)$ & $(0.0000)$ & $(0.0002)$ & $(0.0703)$ \\
\hline \multirow[t]{2}{*}{ Hindu } & -1.0495 & 0.2702 & -0.1749 & 1.4653 & -0.5349 & 0.4739 & -0.0686 & 0.2162 & 0.2498 \\
\hline & $(0.1410)$ & $(0.7828)$ & $(0.6624)$ & $(0.4020)$ & $(0.4549)$ & $(0.5886)$ & $(0.8700)$ & $(0.6743)$ & $(0.5538)$ \\
\hline \multirow[t]{2}{*}{ Buddhist } & -0.7120 & 2.0342 & -0.6609 & -0.4101 & -0.5138 & -0.1553 & 1.8131 & 1.8131 & 1.8131 \\
\hline & $(0.3910)$ & $(0.2479)$ & $(0.5112)$ & $(0.6610)$ & $(0.5090)$ & $(0.9135)$ & $(0.2980)$ & $(0.2976)$ & $(0.2976)$ \\
\hline \multirow[t]{2}{*}{ Others } & 0.2740 & -0.0610 & 0.1265 & -0.2055 & $0.3697^{* *}$ & 0.0295 & $-1.0764 * * *$ & $-1.1981^{* * *}$ & $-1.8094^{* * *}$ \\
\hline & $(0.1240)$ & $(0.8020)$ & $(0.4169)$ & $(0.1500)$ & $(0.0118)$ & $(0.8567)$ & $(0.0060)$ & $(0.0002)$ & $(0.0007)$ \\
\hline $\mathrm{R}^{2}$ & & 0.076 & & & 0.109 & & & 0.079 & \\
\hline N. observ. & & 28956 & & & 16693 & & & 4803 & \\
\hline
\end{tabular}


Panel J: Private ownership should be increased?

\begin{tabular}{|c|c|c|c|c|c|c|c|c|c|}
\hline & \multicolumn{9}{|c|}{ Dominant religion: } \\
\hline & \multicolumn{3}{|c|}{ Catholic } & \multicolumn{3}{|c|}{ Protestant } & \multicolumn{3}{|c|}{ Muslim } \\
\hline & \multicolumn{3}{|c|}{ Religious intensity } & \multicolumn{3}{|c|}{ Religious intensity } & \multicolumn{3}{|c|}{ Religious intensity } \\
\hline & Raised & $\begin{array}{l}\text { Raised + } \\
\text { Currently }\end{array}$ & $\begin{array}{l}\text { Raised+ } \\
\text { Currently } \\
+ \text { Actively }\end{array}$ & Raised & $\begin{array}{l}\text { Raised + } \\
\text { Currently }\end{array}$ & $\begin{array}{l}\text { Raised+ } \\
\text { Currently } \\
+ \text { Actively }\end{array}$ & Raised & $\begin{array}{l}\text { Raised + } \\
\text { Currently }\end{array}$ & $\begin{array}{l}\text { Raised+ } \\
\text { Currently } \\
+ \text { Actively }\end{array}$ \\
\hline Catholic & $\begin{array}{l}-0.0503 \\
(0.2710)\end{array}$ & $\begin{array}{l}0.1040^{* *} \\
(0.0396)\end{array}$ & $\begin{array}{l}0.1706^{* * *} \\
(0.0013)\end{array}$ & $\begin{array}{l}-0.1132 \\
(0.2060)\end{array}$ & $\begin{array}{l}-0.0550 \\
(0.4854)\end{array}$ & $\begin{array}{c}0.1579^{*} \\
(0.0537)\end{array}$ & $\begin{array}{l}-0.7320 \\
(0.3670)\end{array}$ & $\begin{array}{l}-0.0386 \\
(0.9322)\end{array}$ & $\begin{array}{c}-1.0111^{* * *} \\
(0.0025)\end{array}$ \\
\hline Protestant & $\begin{array}{c}0.1406 \\
(0.3440)\end{array}$ & $\begin{array}{c}0.1435 \\
(0.3390)\end{array}$ & $\begin{array}{c}-0.0508 \\
(0.7035)\end{array}$ & $\begin{array}{c}0.1298 * * * \\
(0.0100)\end{array}$ & $\begin{array}{l}0.1692^{* * *} \\
(0.0037)\end{array}$ & $\begin{array}{c}0.1195 \\
(0.1405)\end{array}$ & $\begin{array}{c}1.1276 \\
(0.4480)\end{array}$ & $\begin{array}{c}-0.9636 \\
(0.2027)\end{array}$ & $\begin{array}{c}1.3960 \\
(0.3394)\end{array}$ \\
\hline Jew & $\begin{array}{l}-0.6272 \\
(0.4270)\end{array}$ & $\begin{array}{l}-0.3629 \\
(0.6212)\end{array}$ & $\begin{array}{c}0.3934 \\
(0.7966)\end{array}$ & $\begin{array}{c}0.6675 \\
(0.1410)\end{array}$ & $\begin{array}{c}0.0892 \\
(0.8261)\end{array}$ & $\begin{array}{c}-0.0508 \\
(0.9212)\end{array}$ & $\begin{array}{c}0.1958 \\
(0.9440)\end{array}$ & $\begin{array}{c}-0.9106 \\
(0.6754)\end{array}$ & $\begin{array}{c}-0.0438 \\
(0.9886)\end{array}$ \\
\hline Muslim & $\begin{array}{c}0.7798 \\
(0.1500)\end{array}$ & $\begin{array}{c}0.1583 \\
(0.8295)\end{array}$ & $\begin{array}{c}0.8031 \\
(0.2672)\end{array}$ & $\begin{array}{l}-0.9323 \\
(0.1380)\end{array}$ & $\begin{array}{l}-0.8805 \\
(0.1081)\end{array}$ & $\begin{array}{c}-1.1094 \\
(0.1340)\end{array}$ & $\begin{array}{l}-0.2171 * \\
(0.0560)\end{array}$ & $\begin{array}{c}0.0568 \\
(0.6960)\end{array}$ & $\begin{array}{c}-0.4189^{* * *} \\
(0.0051)\end{array}$ \\
\hline Hindu & $\begin{array}{c}0.6009 \\
(0.3490)\end{array}$ & $\begin{array}{c}1.3444 \\
(0.1275)\end{array}$ & $\begin{array}{l}-0.8386^{* *} \\
(0.0191)\end{array}$ & $\begin{array}{l}-1.1293 \\
(0.4690)\end{array}$ & $\begin{array}{l}-0.5723 \\
(0.3701)\end{array}$ & $\begin{array}{l}-1.6348^{* *} \\
(0.0365)\end{array}$ & $\begin{array}{c}0.4778 \\
(0.2730)\end{array}$ & $\begin{array}{l}-0.0032 \\
(0.9951)\end{array}$ & $\begin{array}{c}0.2157 \\
(0.6193)\end{array}$ \\
\hline Buddhist & $\begin{array}{l}-0.1937 \\
(0.7980)\end{array}$ & $\begin{array}{l}-0.5825 \\
(0.7135)\end{array}$ & $\begin{array}{c}0.2054 \\
(0.8254)\end{array}$ & $\begin{array}{l}-0.1913 \\
(0.8220)\end{array}$ & $\begin{array}{l}-1.1990 \\
(0.1008)\end{array}$ & $\begin{array}{c}1.3500 \\
(0.2898)\end{array}$ & $\begin{array}{l}-0.9618 \\
(0.5890)\end{array}$ & $\begin{array}{c}-0.9618 \\
(0.5888)\end{array}$ & $\begin{array}{c}-0.9618 \\
(0.5888)\end{array}$ \\
\hline Others & $\begin{array}{l}-0.1817 \\
(0.2620)\end{array}$ & $\begin{array}{l}-0.0916 \\
(0.6862)\end{array}$ & $\begin{array}{c}0.0881 \\
(0.5390)\end{array}$ & $\begin{array}{l}-0.2406^{*} \\
(0.0610)\end{array}$ & $\begin{array}{l}-0.6109^{* * *} \\
(0.0000)\end{array}$ & $\begin{array}{c}-0.1329 \\
(0.3669)\end{array}$ & $\begin{array}{l}-0.2521 \\
(0.5320)\end{array}$ & $\begin{array}{l}-0.9405^{\text {*** }} \\
(0.0040)\end{array}$ & $\begin{array}{c}-0.1767 \\
(0.7474)\end{array}$ \\
\hline $\mathrm{R}^{2}$ & & 0.100 & & & 0.113 & & & 0.069 & \\
\hline N. observ. & & 27293 & & & 16674 & & & 4890 & \\
\hline
\end{tabular}

\section{Panel K: Competition is good}

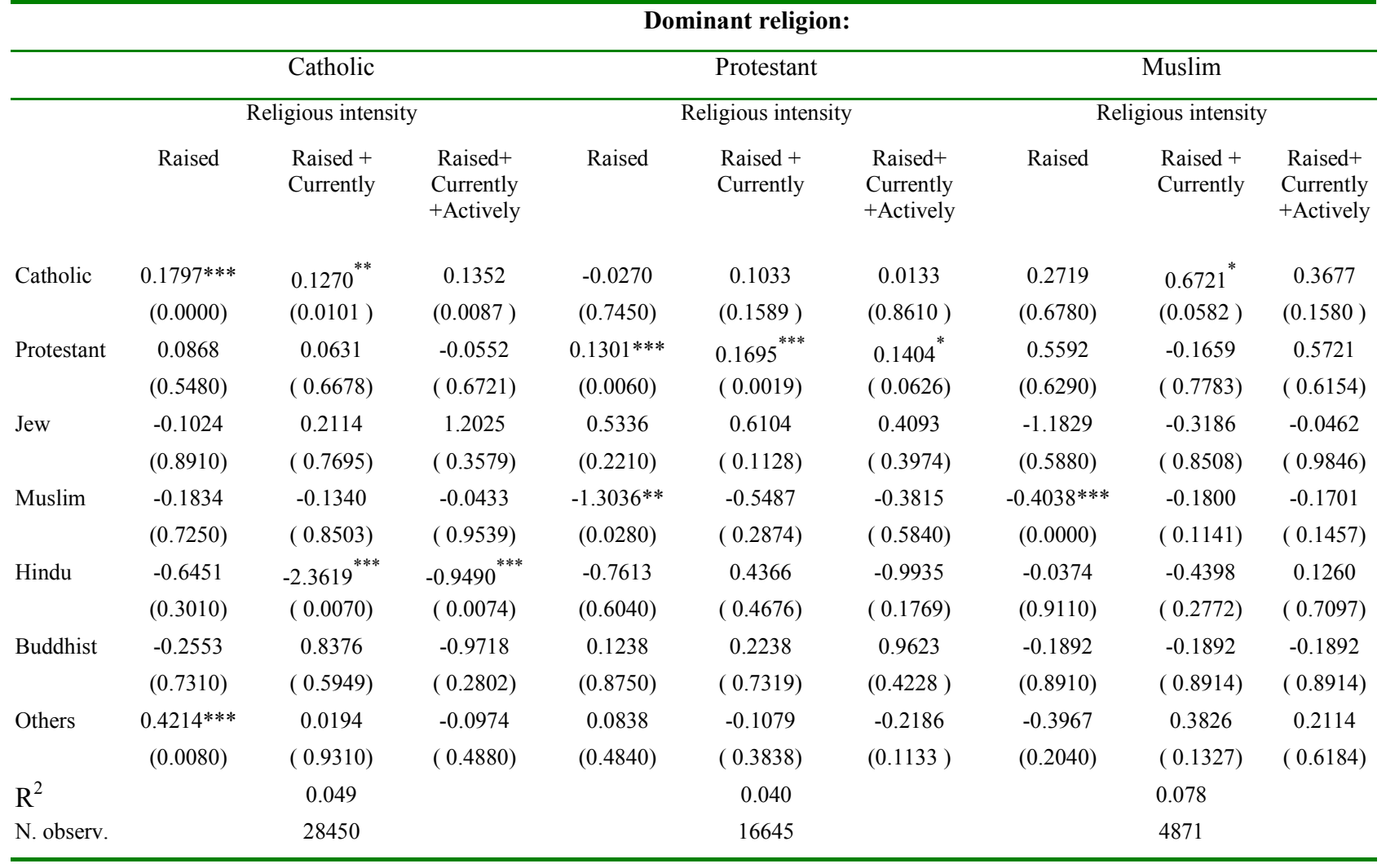


Panel L: Thrift to be taught to children

\begin{tabular}{|c|c|c|c|c|c|c|c|c|c|}
\hline & \multicolumn{9}{|c|}{ Dominant religion: } \\
\hline & \multicolumn{3}{|c|}{ Catholic } & \multicolumn{3}{|c|}{ Protestant } & \multicolumn{3}{|c|}{ Muslim } \\
\hline & \multicolumn{3}{|c|}{ Religious intensity } & \multicolumn{3}{|c|}{ Religious intensity } & \multicolumn{3}{|c|}{ Religious intensity } \\
\hline & Raised & $\begin{array}{l}\text { Raised + } \\
\text { Currently }\end{array}$ & $\begin{array}{l}\text { Raised+ } \\
\text { Currently } \\
\text { +Actively }\end{array}$ & Raised & $\begin{array}{l}\text { Raised + } \\
\text { Currently }\end{array}$ & $\begin{array}{l}\text { Raised+ } \\
\text { Currently } \\
+ \text { Actively }\end{array}$ & Raised & $\begin{array}{l}\text { Raised + } \\
\text { Currently }\end{array}$ & $\begin{array}{l}\text { Raised+ } \\
\text { Currently } \\
+ \text { Actively }\end{array}$ \\
\hline Catholic & $\begin{array}{l}0.0141 * * \\
(0.0360)\end{array}$ & $\begin{array}{l}0.0233^{* * *} \\
(0.0020)\end{array}$ & $\begin{array}{l}0.0253^{* * *} \\
(0.0011)\end{array}$ & $\begin{array}{c}0.0009 \\
(0.9450)\end{array}$ & $\begin{array}{c}0.0080 \\
(0.5382)\end{array}$ & $\begin{array}{l}-0.0005 \\
(0.9722)\end{array}$ & $\begin{array}{l}-0.1060 \\
(0.4050)\end{array}$ & $\begin{array}{l}-0.0018 \\
(0.9796)\end{array}$ & $\begin{array}{c}0.0344 \\
(0.5104)\end{array}$ \\
\hline Protestant & $\begin{array}{c}0.0041 \\
(0.8470)\end{array}$ & $\begin{array}{c}0.0326 \\
(0.1507)\end{array}$ & $\begin{array}{l}-0.0015 \\
(0.9375)\end{array}$ & $\begin{array}{c}0.0009 \\
(0.9190)\end{array}$ & $\begin{array}{l}0.0232^{* *} \\
(0.0184)\end{array}$ & $\begin{array}{l}-0.0075 \\
(0.5449)\end{array}$ & $\begin{array}{l}0.4149 * \\
(0.0750)\end{array}$ & $\begin{array}{c}0.1246 \\
(0.2933)\end{array}$ & $\begin{array}{l}0.8019^{* * *} \\
(0.0005)\end{array}$ \\
\hline Jew & $\begin{array}{c}0.0202 \\
(0.8580)\end{array}$ & $\begin{array}{c}0.0232 \\
(0.8395)\end{array}$ & $\begin{array}{c}0.2575 \\
(0.1617)\end{array}$ & $\begin{array}{l}-0.0419 \\
(0.5440)\end{array}$ & $\begin{array}{c}-0.0463 \\
(0.5005)\end{array}$ & $\begin{array}{c}-0.0386 \\
(0.6117)\end{array}$ & $\begin{array}{c}0.3771 \\
(0.3910)\end{array}$ & $\begin{array}{c}0.5313 \\
(0.1192)\end{array}$ & $\begin{array}{c}-0.3958 \\
(0.4117)\end{array}$ \\
\hline Muslim & $\begin{array}{c}0.0194 \\
(0.8080)\end{array}$ & $\begin{array}{c}0.0006 \\
(0.9953)\end{array}$ & $\begin{array}{c}0.0632 \\
(0.5701)\end{array}$ & $\begin{array}{l}-0.0048 \\
(0.9550)\end{array}$ & $\begin{array}{c}-0.0830 \\
(0.3367)\end{array}$ & $\begin{array}{l}-0.1791^{*} \\
(0.0681)\end{array}$ & $\begin{array}{c}0.0598 * * * \\
(0.0010)\end{array}$ & $\begin{array}{l}0.0657^{* * *} \\
(0.0037)\end{array}$ & $\begin{array}{c}-0.0086 \\
(0.7107)\end{array}$ \\
\hline Hindu & $\begin{array}{c}0.0312 \\
(0.7630)\end{array}$ & $\begin{array}{c}0.0052 \\
(0.9715)\end{array}$ & $\begin{array}{l}-0.0095 \\
(0.8712)\end{array}$ & $\begin{array}{c}0.1497 \\
(0.1150)\end{array}$ & $\begin{array}{c}0.1005 \\
(0.2777)\end{array}$ & $\begin{array}{c}0.0967 \\
(0.3113)\end{array}$ & $\begin{array}{c}0.0173 \\
(0.7970)\end{array}$ & $\begin{array}{l}0.1552^{*} \\
(0.0566)\end{array}$ & $\begin{array}{c}0.0544 \\
(0.4205)\end{array}$ \\
\hline Buddhist & $\begin{array}{l}-0.0317 \\
(0.7940)\end{array}$ & $\begin{array}{c}-0.1068 \\
(0.6469)\end{array}$ & $\begin{array}{c}-0.0738 \\
(0.6120)\end{array}$ & $\begin{array}{c}0.2119 \\
(0.1300)\end{array}$ & $\begin{array}{c}0.0788 \\
(0.5322)\end{array}$ & $\begin{array}{c}0.0800 \\
(0.7047)\end{array}$ & $\begin{array}{l}0.5063 * \\
(0.0700)\end{array}$ & $\begin{array}{l}0.5063^{*} \\
(0.0695)\end{array}$ & $\begin{array}{c}0.5063^{*} \\
(0.0695)\end{array}$ \\
\hline Others & $\begin{array}{l}-0.0089 \\
(0.7270)\end{array}$ & $\begin{array}{c}0.0282 \\
(0.4221)\end{array}$ & $\begin{array}{l}-0.0373 \\
(0.1011)\end{array}$ & $\begin{array}{c}0.0322 \\
(0.1530)\end{array}$ & $\begin{array}{c}0.0213 \\
(0.3728)\end{array}$ & $\begin{array}{l}-0.0243 \\
(0.3376)\end{array}$ & $\begin{array}{l}-0.0730 \\
(0.2460)\end{array}$ & $\begin{array}{l}-0.0279 \\
(0.5845)\end{array}$ & $\begin{array}{c}0.0786 \\
(0.3571)\end{array}$ \\
\hline $\mathrm{R}^{2}$ & & 0.078 & & & 0.147 & & & 0.077 & \\
\hline N. observ. & & 37635 & & & 25335 & & & 5010 & \\
\hline
\end{tabular}

Panel M: Poor are lazy

Dominant religion:

\begin{tabular}{|c|c|c|c|c|c|c|c|c|c|}
\hline & \multicolumn{3}{|c|}{ Catholic } & \multicolumn{3}{|c|}{ Protestant } & \multicolumn{3}{|c|}{ Muslim } \\
\hline & \multicolumn{3}{|c|}{ Religious intensity } & \multicolumn{3}{|c|}{ Religious intensity } & \multicolumn{3}{|c|}{ Religious intensity } \\
\hline & Raised & $\begin{array}{l}\text { Raised + } \\
\text { Currently }\end{array}$ & $\begin{array}{l}\text { Raised+ } \\
\text { Currently } \\
\text { +Actively }\end{array}$ & Raised & $\begin{array}{l}\text { Raised + } \\
\text { Currently }\end{array}$ & $\begin{array}{l}\text { Raised+ } \\
\text { Currently } \\
+ \text { Actively }\end{array}$ & Raised & $\begin{array}{l}\text { Raised + } \\
\text { Currently }\end{array}$ & $\begin{array}{l}\text { Raised+ } \\
\text { Currently } \\
+ \text { Actively }\end{array}$ \\
\hline Catholic & $\begin{array}{l}-0.0057 \\
(0.1430)\end{array}$ & $\begin{array}{c}0.0014 \\
(0.7343)\end{array}$ & $\begin{array}{c}0.0043 \\
(0.3259)\end{array}$ & $\begin{array}{c}0.0082 \\
(0.2760)\end{array}$ & $\begin{array}{l}0.0249^{* * *} \\
(0.0014)\end{array}$ & $\begin{array}{l}0.0179^{* *} \\
(0.0234)\end{array}$ & $\begin{array}{l}-0.2196^{*} \\
(0.0710)\end{array}$ & $\begin{array}{l}0.1721^{* * *} \\
(0.0062)\end{array}$ & $\begin{array}{c}0.0665 \\
(0.1737)\end{array}$ \\
\hline Protestant & $\begin{array}{c}0.0074 \\
(0.5380)\end{array}$ & $\begin{array}{c}0.0062 \\
(0.6303)\end{array}$ & $\begin{array}{c}0.0135 \\
(0.2163)\end{array}$ & $\begin{array}{l}0.0109 * * \\
(0.0360)\end{array}$ & $\begin{array}{l}0.0171^{* * *} \\
(0.0037)\end{array}$ & $\begin{array}{l}0.0312^{* * *} \\
(0.0000)\end{array}$ & $\begin{array}{l}-0.0818 \\
(0.6910)\end{array}$ & $\begin{array}{l}-0.0687 \\
(0.3227)\end{array}$ & $\begin{array}{c}0.0303 \\
(0.8789)\end{array}$ \\
\hline Jew & $\begin{array}{c}0.0117 \\
(0.8560)\end{array}$ & $\begin{array}{c}0.0381 \\
(0.5611)\end{array}$ & $\begin{array}{c}0.1269 \\
(0.2246)\end{array}$ & $\begin{array}{c}0.0165 \\
(0.6900)\end{array}$ & $\begin{array}{c}0.0094 \\
(0.8181)\end{array}$ & $\begin{array}{c}0.0003 \\
(0.9952)\end{array}$ & $\begin{array}{c}0.0213 \\
(0.9550)\end{array}$ & $\begin{array}{l}-0.1055 \\
(0.7206)\end{array}$ & $\begin{array}{l}0.9095^{* *} \\
(0.0293)\end{array}$ \\
\hline Hindu & $\begin{array}{c}-0.1541 * * \\
(0.0100)\end{array}$ & $\begin{array}{l}-0.0395 \\
(0.6694)\end{array}$ & $\begin{array}{l}-0.0475 \\
(0.1547)\end{array}$ & $\begin{array}{c}0.1825 * * * \\
(0.0010)\end{array}$ & $\begin{array}{l}0.1898^{* * *} \\
(0.0005)\end{array}$ & $\begin{array}{l}0.1800^{* * *} \\
(0.0014)\end{array}$ & $\begin{array}{l}0.1523 * * \\
(0.0100)\end{array}$ & $\begin{array}{l}-0.0413 \\
(0.5587)\end{array}$ & $\begin{array}{l}0.1567^{* * *} \\
(0.0080)\end{array}$ \\
\hline Buddhist & $\begin{array}{l}-0.0014 \\
(0.9840)\end{array}$ & $\begin{array}{c}-0.0061 \\
(0.9630)\end{array}$ & $\begin{array}{c}0.1134 \\
(0.1966)\end{array}$ & $\begin{array}{l}-0.0605 \\
(0.4640)\end{array}$ & $\begin{array}{l}-0.0956 \\
(0.1984)\end{array}$ & $\begin{array}{c}0.1067 \\
(0.3915)\end{array}$ & $\begin{array}{c}0.1373 \\
(0.6420)\end{array}$ & $\begin{array}{c}0.1373 \\
(0.6416)\end{array}$ & $\begin{array}{c}0.1373 \\
(0.6416)\end{array}$ \\
\hline Others & $\begin{array}{l}-0.0054 \\
(0.7110)\end{array}$ & $\begin{array}{l}0.0522^{* * *} \\
(0.0098)\end{array}$ & $\begin{array}{l}0.0284^{* *} \\
(0.0298)\end{array}$ & $\begin{array}{c}0.0441 * * * \\
(0.0010)\end{array}$ & $\begin{array}{l}-0.0336^{* *} \\
(0.0188)\end{array}$ & $\begin{array}{l}0.1038^{* * *} \\
(0.0000)\end{array}$ & $\begin{array}{c}0.0066 \\
(0.9090)\end{array}$ & $\begin{array}{c}0.0124 \\
(0.7907)\end{array}$ & $\begin{array}{c}-0.0045 \\
(0.9558)\end{array}$ \\
\hline$R^{2}$ & & 0.278 & & & 0.273 & & & 0.093 & \\
\hline N. observ. & & 37421 & & & 24562 & & & 4580 & \\
\hline
\end{tabular}




\section{Table 6. Post Concilium}

Each panel reports the coefficients of an OLS regression, whose dependent variable is indicated at the top of the panel. dependent variables are defined in the legend of Table 1. Regressions include (coefficients not reported) the same demographic controls as in Table 2 (health, male, age, education, social class, income), an indicator variable equal to 1 if a person answers no to the question "Do you believe in God?", country fixed effects, and survey-year dummies. *** indicate the coefficient is different from zero at the 1 percent level, ** at the 5 percent level, and * at the 10 percent level.

Panel A: Attitudes toward others and the government

$\begin{array}{ccccccc}\begin{array}{c}\text { Trust } \\ \text { people }\end{array} & \begin{array}{c}\text { Intolerant } \\ \text { toward } \\ \text { other races }\end{array} & \begin{array}{c}\text { Intolerant } \\ \text { toward } \\ \text { immigrants }\end{array} & \begin{array}{c}\text { Average } \\ \text { intolerance }\end{array} & \begin{array}{c}\text { Trust the } \\ \text { government }\end{array} & \begin{array}{c}\text { Trust the } \\ \text { police }\end{array} & \begin{array}{c}\text { Trust the } \\ \text { armed } \\ \text { forces }\end{array}\end{array}$

\begin{tabular}{|c|c|c|c|c|c|c|c|c|}
\hline Raised Catholic & $\begin{array}{c}-0.0156^{* * *} \\
(0.0061)\end{array}$ & $\begin{array}{l}.0041^{* * *} \\
(0.0044)\end{array}$ & $\begin{array}{l}0.0080^{* * *} \\
(0.0049)\end{array}$ & $\begin{array}{l}0.0083^{* * *} \\
(0.0034)\end{array}$ & $\begin{array}{l}0.0014 * * \\
(0.0197)\end{array}$ & \multicolumn{2}{|c|}{$\begin{array}{l}0.0081 * * \\
(0.0118)\end{array}$} & $\begin{array}{c}-0.0435^{* *} \\
(0.0120)\end{array}$ \\
\hline (Raised + Currently) Catholic & -0.0072 & $0.0084 *$ & 0.0053 & $0.0264^{* * *}$ & $0.1321^{* * *}$ & \multicolumn{2}{|c|}{$\begin{array}{l}0.1372^{* * *} \\
(0.0000)\end{array}$} & $0.1764^{* * *}$ \\
\hline (Raised + Currently + Actively) & $\begin{array}{c}(0.2645) \\
0.0392 * * *\end{array}$ & $(0.0782)$ & $\begin{array}{l}(0.3161) \\
0.0034^{* * *}\end{array}$ & $\begin{array}{l}(0.0000) \\
0.0302^{* * *}\end{array}$ & $\begin{array}{l}(0.0000) \\
0.1314^{* * *}\end{array}$ & \multirow{2}{*}{\multicolumn{2}{|c|}{$\begin{array}{l}0.2307^{* * *} \\
(0.0000)\end{array}$}} & $\begin{array}{l}(0.0000) \\
0.293^{* * *}\end{array}$ \\
\hline Catholic & $(0.0000)$ & $(0.0374)$ & $(0.5301)$ & $(0.0000)$ & $(0.0000)$ & & & $(0.0000)$ \\
\hline Post concilium & $\begin{array}{cc}-0.0192 * * * & 0.0 \\
(0.0051) & (0\end{array}$ & $\begin{array}{l}.0143 * * * \\
(0.0037)\end{array}$ & $\begin{array}{l}0.0091^{* * *} \\
(0.0040)\end{array}$ & $\begin{array}{l}0.0108 * * * \\
(0.0027)\end{array}$ & $\begin{array}{l}0.0328 * * \\
(0.0136)\end{array}$ & \multicolumn{2}{|c|}{$\begin{array}{l}0.0598 * * * \\
(0.0097)\end{array}$} & $\begin{array}{c}0.0408 * * * \\
(0.0099)\end{array}$ \\
\hline $\begin{array}{l}\text { Raised Catholic } \mathrm{X} \text { Post } \\
\text { concilium }\end{array}$ & $\begin{array}{ll}0.0062^{* * *} & -0 . \\
(0.0093) & (0\end{array}$ & $\begin{array}{l}.0057^{* * *} \\
0.0067)\end{array}$ & $\begin{array}{c}-0.0190^{* * *} \\
(0.0076)\end{array}$ & $\begin{array}{c}-0.0147^{* * *} \\
(0.0052)\end{array}$ & $\begin{array}{l}0.0106^{* *} \\
(0.0270)\end{array}$ & \multicolumn{2}{|c|}{$\begin{array}{l}0.0619 * * \\
(0.0179)\end{array}$} & $\begin{array}{c}0.0846^{* * * *} \\
(0.0181)\end{array}$ \\
\hline $\begin{array}{l}\text { (Raised }+ \text { Currently Catholic) } \\
\text { X Post concilium }\end{array}$ & $\begin{array}{c}0.0076 \\
(0.4175)\end{array}$ & $\begin{array}{l}0.0002 \\
0.9734)\end{array}$ & $\begin{array}{c}0.0052 \\
(0.4914)\end{array}$ & $\begin{array}{c}-0.0111^{* *} \\
(0.0333)\end{array}$ & $\begin{array}{l}-0.0084 \\
(0.7331)\end{array}$ & \multicolumn{2}{|c|}{$\begin{array}{l}0.0328^{*} \\
(0.0671)\end{array}$} & $\begin{array}{c}0.0122 \\
(0.5037)\end{array}$ \\
\hline $\begin{array}{l}\text { (Raised }+ \text { Currently }+ \text { Actively } \\
\text { Catholic) X Concilium }\end{array}$ & $\begin{array}{l}-0.0031 \\
(0.7608)\end{array}$ & $\begin{array}{l}-0.0029 \\
0.6970)\end{array}$ & $\begin{array}{l}0.0177 * * \\
(0.0389)\end{array}$ & $\begin{array}{l}-0.0188^{* * *} \\
(0.0014)\end{array}$ & $\begin{array}{l}0.0955^{* * *} \\
(0.0007)\end{array}$ & \multicolumn{2}{|c|}{$\begin{array}{r}0.0413 * * \\
(0.0342)\end{array}$} & $\begin{array}{l}-0.0443 * * \\
(0.0261)\end{array}$ \\
\hline $\begin{array}{l}\text { Number of obs. } \\
R \text { squared }\end{array}$ & $\begin{array}{l}91656 \\
0.094\end{array}$ & $\begin{array}{l}89530 \\
0.074\end{array}$ & $\begin{array}{c}85614 \\
0.071\end{array}$ & $\begin{array}{l}84179 \\
0.273\end{array}$ & $\begin{array}{l}47667 \\
0.133\end{array}$ & \multicolumn{2}{|c|}{$\begin{array}{c}87680 \\
0.172\end{array}$} & $\begin{array}{l}88124 \\
0.198\end{array}$ \\
\hline \multicolumn{9}{|l|}{ Panel B: Attitudes toward women } \\
\hline & $\begin{array}{l}\text { When jobs are } \\
\text { scarce, men } \\
\text { should have } \\
\text { more right to a } \\
\text { job than women }\end{array}$ & \multicolumn{2}{|c|}{$\begin{array}{c}\text { Do you think } \\
\text { that women } \\
\text { should have } \\
\text { children in order } \\
\text { to be fulfilled }\end{array}$} & $\begin{array}{l}\text { Being a } \\
\text { lousewife is just } \\
\text { as fulfilling as } \\
\text { working for pay }\end{array}$ & \multicolumn{2}{|c|}{$\begin{array}{l}\text { Both the } \\
\text { husband and } \\
\text { wife should } \\
\text { contribute to } \\
\text { household } \\
\text { income }\end{array}$} & \multicolumn{2}{|c|}{$\begin{array}{l}\text { A university } \\
\text { education is } \\
\text { more important } \\
\text { for a boy than } \\
\text { for a girl }\end{array}$} \\
\hline Raised Catholic & $\begin{array}{l}0.1054 * * \\
(0.0145)\end{array}$ & \multicolumn{2}{|c|}{$\begin{array}{l}0.0207 * * * \\
(0.0062)\end{array}$} & $\begin{array}{l}0.0870^{* *} \\
(0.0145)\end{array}$ & \multicolumn{2}{|c|}{$\begin{array}{l}0.0611^{* *} \\
(0.0180)\end{array}$} & \multicolumn{2}{|c|}{$\begin{array}{l}0.0267 * * \\
(0.0226)\end{array}$} \\
\hline (Raised + Currently) Catholic & $\begin{array}{l}0.0909^{* * *} \\
(0.0000)\end{array}$ & \multicolumn{2}{|c|}{$\begin{array}{l}0.0736^{* * *} \\
(0.0000)\end{array}$} & $\begin{array}{l}0.1411^{* * *} \\
(0.0000)\end{array}$ & \multicolumn{2}{|c|}{$\begin{array}{l}0.0448^{* * *} \\
(0.0066)\end{array}$} & \multicolumn{2}{|c|}{$\begin{array}{l}0.0441 * * \\
(0.0322)\end{array}$} \\
\hline $\begin{array}{l}\text { (Raised }+ \text { Currently }+ \text { Actively) } \\
\text { Catholic }\end{array}$ & $\begin{array}{l}0.1641^{* * *} \\
(0.0000)\end{array}$ & \multicolumn{2}{|c|}{$0.1009^{* * *}$} & $\begin{array}{l}0.264^{* * *} \\
(0.0000)\end{array}$ & $0.0823^{* * *}$ & & & $(0.0000)$ \\
\hline Post concilium & $\begin{array}{l}0.0292 * * \\
(0.0113)\end{array}$ & \multicolumn{2}{|c|}{$\begin{array}{l}-0.0051^{* * *} \\
(0.0051)\end{array}$} & $\begin{array}{l}0.0293 * * \\
(0.0112)\end{array}$ & \multicolumn{2}{|c|}{$\begin{array}{l}0.0516^{* *} \\
(0.0124)\end{array}$} & \multicolumn{2}{|c|}{$\begin{array}{c}-0.0307 * * \\
(0.0155)\end{array}$} \\
\hline $\begin{array}{l}\text { Raised Catholic } \mathrm{X} \text { Post } \\
\text { concilium }\end{array}$ & $\begin{array}{c}-0.0954^{* *} \\
(0.0213)\end{array}$ & \multicolumn{2}{|c|}{$\begin{array}{c}-0.0024^{* * *} \\
(0.0094)\end{array}$} & $\begin{array}{c}-0.0912 * * \\
(0.0213)\end{array}$ & \multicolumn{2}{|c|}{$\begin{array}{c}-0.0989 * * \\
(0.0235)\end{array}$} & & $\begin{array}{l}.0093 * * \\
0.0293)\end{array}$ \\
\hline $\begin{array}{l}\text { (Raised + Currently Catholic) } \\
\text { X Post concilium }\end{array}$ & $\begin{array}{l}-0.0686^{* * *} \\
(0.0004)\end{array}$ & & $\begin{array}{l}018^{*} \\
5583)\end{array}$ & $\begin{array}{l}-0.0615^{* * *} \\
(0.0015)\end{array}$ & $\begin{array}{l}-0.03 \\
(0.05\end{array}$ & & & $\begin{array}{l}0.0093 \\
0.7170)\end{array}$ \\
\hline $\begin{array}{l}\text { (Raised }+ \text { Currently }+ \text { Actively } \\
\text { Catholic) X Concilium }\end{array}$ & $\begin{array}{l}-0.1179^{* * *} \\
(0.0000)\end{array}$ & $\begin{aligned}-0.0 \\
(0.6\end{aligned}$ & $\begin{array}{l}312^{* * *} \\
026)\end{array}$ & $\begin{array}{l}-0.1238^{* * *} \\
(0.0000)\end{array}$ & $\begin{aligned}-0.084 \\
(0.00\end{aligned}$ & & & $\begin{array}{l}0.0104 \\
0.7065)\end{array}$ \\
\hline Number of obs. & 72186 & & & 68481 & & & & 38148 \\
\hline$R$ squared & 0.139 & & & 0.101 & & & & 0.123 \\
\hline
\end{tabular}


Panel C: Attitudes toward legal rules

\begin{tabular}{|c|c|c|c|c|c|c|}
\hline & $\begin{array}{l}\text { Trust the } \\
\text { legal system? }\end{array}$ & $\begin{array}{l}\text { Is it justified } \\
\text { to claim } \\
\text { government } \\
\text { benefits you } \\
\text { are not } \\
\text { entitled to? }\end{array}$ & $\begin{array}{l}\text { Is it justified } \\
\text { to avoid a } \\
\text { fare on } \\
\text { public } \\
\text { transport? }\end{array}$ & $\begin{array}{c}\text { Is it justified } \\
\text { to cheat on } \\
\text { taxes? }\end{array}$ & $\begin{array}{l}\text { Is it justified } \\
\text { to buy a } \\
\text { stolen } \\
\text { object? }\end{array}$ & $\begin{array}{c}\text { Is it } \\
\text { justified to } \\
\text { accept a } \\
\text { bribe? }\end{array}$ \\
\hline Raised Catholic & $\begin{array}{l}0.0187 * * \\
(0.0119)\end{array}$ & $\begin{array}{l}-0.0398 * * \\
(0.0309)\end{array}$ & $\begin{array}{c}-0.2140 * * * \\
(0.0325)\end{array}$ & $\begin{array}{c}-0.1245^{* * *} \\
(0.0338)\end{array}$ & $\begin{array}{c}-0.1362 * * * \\
(0.0231)\end{array}$ & $\begin{array}{c}-0.0468 * * \\
(0.0229)\end{array}$ \\
\hline (Raised + Currently) Catholic & $\begin{array}{l}0.1327^{* * *} \\
(0.0000)\end{array}$ & $\begin{array}{l}-0.0473 \\
(0.1555)\end{array}$ & $\begin{array}{l}-0.1941^{* * *} \\
(0.0000)\end{array}$ & $\begin{array}{c}-0.1683^{* * *} \\
(0.0000)\end{array}$ & $\begin{array}{l}-0.136^{* * *} \\
(0.0000)\end{array}$ & $\begin{array}{l}-0.0319 \\
(0.1979)\end{array}$ \\
\hline $\begin{array}{l}\text { (Raised }+ \text { Currently }+ \text { Actively) } \\
\text { Catholic }\end{array}$ & $\begin{array}{l}0.2107^{* * *} \\
(0.0000)\end{array}$ & $\begin{array}{l}-0.0814 * * \\
(0.0144)\end{array}$ & $\begin{array}{l}-0.3323^{* * *} \\
(0.0000)\end{array}$ & $\begin{array}{l}-0.3603^{* * *} \\
(0.0000)\end{array}$ & $\begin{array}{l}-0.2418^{* * *} \\
(0.0000)\end{array}$ & $\begin{array}{l}-0.0946^{* * *} \\
(0.0001)\end{array}$ \\
\hline Post concilium & $\begin{array}{c}0.0484 * * * \\
(0.0098)\end{array}$ & $\begin{array}{l}0.1347 * * \\
(0.0259)\end{array}$ & $\begin{array}{l}0.3127 * * \\
(0.0272)\end{array}$ & $\begin{array}{l}0.1268 * * \\
(0.0283)\end{array}$ & $\begin{array}{l}0.2423 * * \\
(0.0194)\end{array}$ & $\begin{array}{l}0.1422 * * \\
(0.0192)\end{array}$ \\
\hline $\begin{array}{l}\text { Raised Catholic X Post } \\
\text { concilium }\end{array}$ & $\begin{array}{l}0.0365 * * \\
(0.0180)\end{array}$ & $\begin{array}{c}-0.0881 * * \\
(0.0469)\end{array}$ & $\begin{array}{l}-0.0047 * * \\
(0.0493)\end{array}$ & $\begin{array}{l}-0.0640 * \\
(0.0513)\end{array}$ & $\begin{array}{l}0.0073 * * \\
(0.0351)\end{array}$ & $\begin{array}{c}-0.0945^{* *} \\
(0.0348)\end{array}$ \\
\hline $\begin{array}{l}\text { (Raised }+ \text { Currently Catholic) } \\
\text { X Post concilium }\end{array}$ & $\begin{array}{l}-0.0176 \\
(0.3293)\end{array}$ & $\begin{array}{l}-0.0006 \\
(0.9901)\end{array}$ & $\begin{array}{l}-0.1715^{* * *} \\
(0.0006)\end{array}$ & $\begin{array}{l}-0.1287 * * \\
(0.0128)\end{array}$ & $\begin{array}{l}-0.0677^{*} \\
(0.0560)\end{array}$ & $\begin{array}{l}-0.0377 \\
(0.2819)\end{array}$ \\
\hline $\begin{array}{l}\text { (Raised }+ \text { Currently }+ \text { Actively } \\
\text { Catholic) X Concilium }\end{array}$ & $\begin{array}{l}-0.0111 \\
(0.5720)\end{array}$ & $\begin{array}{l}-0.1462^{* * *} \\
(0.0045)\end{array}$ & $\begin{array}{l}-0.1038^{*} \\
(0.0553)\end{array}$ & $\begin{array}{l}-0.2403^{* * *} \\
(0.0000)\end{array}$ & $\begin{array}{l}-0.1693^{* * *} \\
(0.0000)\end{array}$ & $\begin{array}{l}-0.1064^{* * *} \\
(0.0054)\end{array}$ \\
\hline $\begin{array}{l}\text { Number of obs. } \\
R \text { squared }\end{array}$ & $\begin{array}{l}88157 \\
0.092\end{array}$ & $\begin{array}{l}86095 \\
0.095\end{array}$ & $\begin{array}{l}87224 \\
0.126\end{array}$ & $\begin{array}{l}86627 \\
0.099\end{array}$ & $\begin{array}{l}87356 \\
0.073\end{array}$ & $\begin{array}{l}87082 \\
0.070\end{array}$ \\
\hline
\end{tabular}

Panel D: Attitudes toward then market

$\begin{array}{ccc}\text { Inequality of income vs. } & \text { Private vs. public } \\ \text { incentives } & \text { ownership } & \begin{array}{c}\text { Competition is good or } \\ \text { harmful }\end{array}\end{array}$

\begin{tabular}{|c|c|c|c|}
\hline \multirow[t]{2}{*}{ Raised Catholic } & $-0.0176^{* *}$ & $0.0638 * *$ & $0.2218 * *$ \\
\hline & $(0.0482)$ & $(0.0466)$ & $(0.0422)$ \\
\hline \multirow[t]{2}{*}{ (Raised + Currently) Catholic } & -0.0458 & $0.2776^{* * *}$ & $0.228^{* * *}$ \\
\hline & $(0.3285)$ & $(0.0000)$ & $(0.0000)$ \\
\hline (Raised + Currently + & -0.0375 & $0.443^{* * *}$ & $0.265^{* * *}$ \\
\hline \multicolumn{2}{|c|}{ Actively) Catholic } & $(0.0000)$ & $(0.0000)$ \\
\hline \multirow[t]{2}{*}{ Post concilium } & $0.0914 * *$ & $0.1932 * *$ & $0.0962 * *$ \\
\hline & $(0.0372)$ & $(0.0354)$ & $(0.0324)$ \\
\hline \multirow{2}{*}{$\begin{array}{l}\text { Raised Catholic } \mathrm{X} \text { Post } \\
\text { concilium }\end{array}$} & $0.0215^{*}$ & $-0.2546^{*}$ & $-0.1929^{*}$ \\
\hline & $(0.0721)$ & $(0.0696)$ & $(0.0630)$ \\
\hline \multirow{2}{*}{$\begin{array}{l}\text { (Raised }+ \text { Currently Catholic) } \\
\text { X Post concilium }\end{array}$} & 0.0237 & $-0.3931^{* * *}$ & $-0.2924^{* * *}$ \\
\hline & $(0.7199)$ & $(0.0000)$ & $(0.0000)$ \\
\hline \multirow{2}{*}{$\begin{array}{l}\text { (Raised }+ \text { Currently }+ \text { Actively } \\
\text { Catholic) X Concilium }\end{array}$} & -0.0279 & $-0.5602^{* * *}$ & $-0.3042^{* * *}$ \\
\hline & $(0.7097)$ & $(0.0000)$ & $(0.0000)$ \\
\hline \multirow{2}{*}{$\begin{array}{l}\text { Number of obs. } \\
R \text { squared }\end{array}$} & 69016 & 66833 & 68177 \\
\hline & 0.095 & 0.134 & 0.066 \\
\hline
\end{tabular}


Panel D: Attitudes toward thriftiness and market's fairness

\begin{tabular}{|c|c|c|c|c|c|}
\hline & $\begin{array}{l}\text { Thrift to be } \\
\text { encouraged }\end{array}$ & $\begin{array}{l}\text { Individual vs. } \\
\text { government } \\
\text { responsibility }\end{array}$ & $\begin{array}{l}\text { Hard work } \\
\text { improves life }\end{array}$ & $\begin{array}{l}\text { Wealth can } \\
\text { grow for } \\
\text { everyone }\end{array}$ & Poor are lazy \\
\hline Raised Catholic & $\begin{array}{l}0.0076^{* * *} \\
(0.0063)\end{array}$ & $\begin{array}{l}-0.0145 * * \\
(0.0478)\end{array}$ & $\begin{array}{l}0.0419^{* *} \\
(0.0481)\end{array}$ & $\begin{array}{c}-0.0769 * * \\
(0.0474)\end{array}$ & $\begin{array}{l}0.0002^{* * *} \\
(0.0038)\end{array}$ \\
\hline (Raised + Currently) Catholic & $\begin{array}{l}0.0131^{*} \\
(0.0533)\end{array}$ & $\begin{array}{l}0.1458^{* * *} \\
(0.0017)\end{array}$ & $\begin{array}{l}0.2131^{* * *} \\
(0.0000)\end{array}$ & $\begin{array}{c}0.0304 \\
(0.5080)\end{array}$ & $\begin{array}{l}0.0129^{* * *} \\
(0.0018)\end{array}$ \\
\hline $\begin{array}{l}\text { (Raised }+ \text { Currently }+ \text { Actively) } \\
\text { Catholic }\end{array}$ & $\begin{array}{c}0.008 \\
(0.2402)\end{array}$ & $\begin{array}{l}0.2133^{* * *} \\
(0.0000)\end{array}$ & $\begin{array}{l}0.2900^{* * *} \\
(0.0000)\end{array}$ & $\begin{array}{l}0.2633^{* * *} \\
(0.0000)\end{array}$ & $\begin{array}{l}0.0174^{* * *} \\
(0.0000)\end{array}$ \\
\hline Post concilium & $\begin{array}{l}-0.0042^{* * *} \\
(0.0052)\end{array}$ & $\begin{array}{l}0.0786 * * \\
(0.0371)\end{array}$ & $\begin{array}{l}0.1000 * * \\
(0.0370)\end{array}$ & $\begin{array}{c}-0.0097 * * \\
(0.0365)\end{array}$ & $\begin{array}{c}0.0215 * * * \\
(0.0032)\end{array}$ \\
\hline $\begin{array}{l}\text { Raised Catholic X Post } \\
\text { concilium }\end{array}$ & $\begin{array}{l}0.0011^{* * *} \\
(0.0095)\end{array}$ & $\begin{array}{l}-0.0409^{*} \\
(0.0700)\end{array}$ & $\begin{array}{l}0.1145^{*} \\
(0.0719)\end{array}$ & $\begin{array}{l}0.0275^{*} \\
(0.0707)\end{array}$ & $\begin{array}{c}-0.0159 * * * \\
(0.0058)\end{array}$ \\
\hline $\begin{array}{l}\text { (Raised }+ \text { Currently Catholic) } \\
\text { X Post concilium }\end{array}$ & $\begin{array}{l}0.0200 * * \\
(0.0377)\end{array}$ & $\begin{array}{l}-0.1514 * * \\
(0.0177)\end{array}$ & $\begin{array}{c}0.0978 \\
(0.1375)\end{array}$ & $\begin{array}{c}0.0714 \\
(0.2697)\end{array}$ & $\begin{array}{l}-0.0189^{* * *} \\
(0.0012)\end{array}$ \\
\hline $\begin{array}{l}\text { (Raised }+ \text { Currently }+ \text { Actively } \\
\text { Catholic) X Concilium }\end{array}$ & $\begin{array}{l}0.0214 * * \\
(0.0440)\end{array}$ & $\begin{array}{l}-0.1722 * * \\
(0.0142)\end{array}$ & $\begin{array}{l}0.1590 * * \\
(0.0334)\end{array}$ & $\begin{array}{l}-0.0447 \\
(0.5424)\end{array}$ & $\begin{array}{l}-0.0267^{* * *} \\
(0.0000)\end{array}$ \\
\hline $\begin{array}{l}\text { Number of obs. } \\
R \text { squared }\end{array}$ & $\begin{array}{l}88696 \\
0.112\end{array}$ & $\begin{array}{c}71970 \\
0.159\end{array}$ & $\begin{array}{c}69198 \\
0.083\end{array}$ & $\begin{array}{l}67327 \\
0.045\end{array}$ & $\begin{array}{c}86305 \\
0.235\end{array}$ \\
\hline
\end{tabular}

